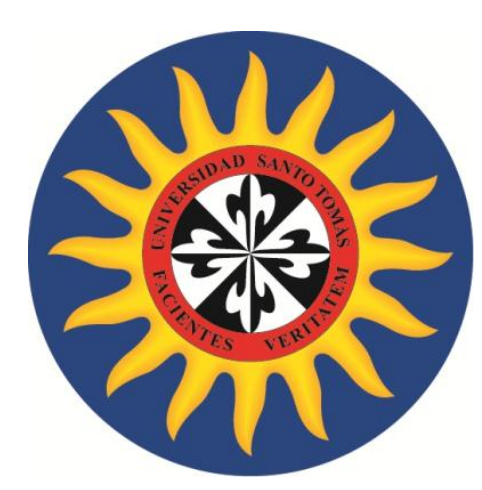

Plan de Negocios para la Creación de un Centro de Acoplamiento "Café y Cultura” en la Ciudad de Tunja

Diana Catalina Archila Peñalosa

Manuela Fernanda Forero Mejía

\title{
Nota del Autor
}

Diana Catalina Archila Peñalosa y Manuela Fernanda Forero Mejía. Estudiantes de la Universidad Santo Tomás, División de Ciencias Administrativas y Contables Administración de Empresas, Tunja, 2014

Trabajo de grado como requisito para optar el título de Administrador de Empresas.

Director: Dr. Norbey Arturo Moreno Duran, Docente Facultad de Administración de Empresas 
Nota de Aceptación

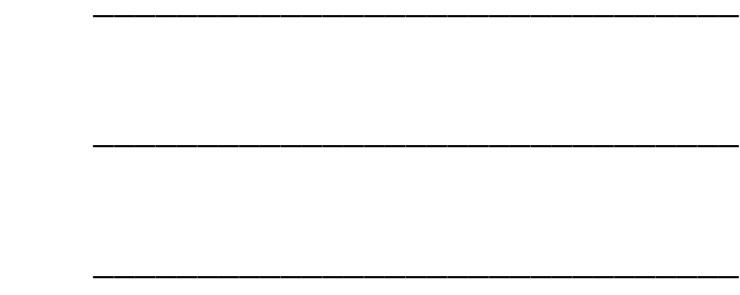

Firma del Presidente del Jurado

Firma del Jurado

Firma del Jurado

Tunja, 8 de Mayo de 2014 
Este trabajo quiero dedicarlo a mis padres por su apoyo y brindarme la oportunidad de estudiar; a mi hermano, por su apoyo incondicional.

De igual manera agradezco a la universidad santo Tomas por brindarnos Las herramientas necesarias para cumplír nuestros objetívos,

Agradezco a La doctora María inés y nuestro director de tesis Norbey. y demás profesores de que alguna manera nos brindaron sus conocimientos para lograr la culminación de nuestro trabajo.

De la misma manera quiero agradecer a mi compañera de tesis, Manuela por formar armonía en nuestro equipo de trabajo y a su familia ya que fueron de apoyo Indispensable, para la culminación de este trabajo, y demás personas que de alguna manera colaboraron para la terminación de este. 
Agradezco a Dios por guiarme y darme sabiduría para culminar con esta maravillosa etapa de mi vida, Quiero dedicar este trabajo a mis padres por su valiosa compañia, apoyo y constante orientación en mí proyecto de vida.

A mi hermano y familia por su respaldo y apoyo.

De igual manera quiero agradecer nuestro director de tesis Norbey Moreno, a la decana María Inés Álvarez por su paciencia, por aportar con sus conocimientos y experiencia para la culminación de este trabajo.

A mis amigos porque con ellos vivi esta etapa de mi vida como una de las mejores experiencías, igualmente a mi compañera de tesis Diana catalina por su comprensión perseverancia y trabajo para hacer de este trabajo una realidad. 


\section{Resumen Ejecutivo}

En Colombia debido a la situación económica que vivimos hoy en día, es indispensable que los profesionales enfoquen todos sus esfuerzos hacia la generación de empleo, con el propósito de contribuir no solo al mejoramiento de su calidad de vida, sino al de toda una comunidad, durante el desarrollo de este trabajo se podrán observar todo los requerimientos utilizados para la apertura de un café cultural además; explica la necesidad de estos espacios culturales como una forma de alejar a los jóvenes de los problemas que presenta la sociedad tales como alcoholismo y drogadicción.

Este proyecto de grado tiene como fin la creación de un centro de acoplamiento cultural en la ciudad de Tunja, que actué con el fin de ofrecer a la comunidad un espacio de sano esparcimiento en conjunto de manifestaciones artísticas que propicien el conocimiento cultural.

\section{Objetivo General}

Desarrollar un plan de negocios para la creación de un Café cultural en la ciudad de Tunja que actué con el fin de ofrecer a la comunidad un espacio de sano esparcimiento en conjunto de manifestaciones artísticas que propicien el conocimiento cultural.

\section{Misión}

Ser reconocidos como el mejor lugar en la ciudad de Tunja de esparcimiento cultural, como gestores y promotores de manifestaciones artísticas mientras los clientes disfrutan de las más deliciosas bebidas de café.

\section{Capítulo de Análisis del Mercado}

Los resultados arrojados fueron positivos, esto quiere decir que la población de la ciudad de Tunja utilizan y les gustaría utilizar el servicio de Café-bar, acompañado de manifestaciones culturales que propicien distracción, además les gustaría que los servicios se 
promocionaran por medio de emisoras, periódicos e internet. La población objetivo serán los estudiantes de 18 a 35 años de edad.

\section{Aspectos Técnicos y Operativos}

Se determinó que la empresa estará ubicada en el barrio Maldonado; los implementos y maquinaria que se utilizaran en la realización de las labores cotidianas, además políticas de gestión de calidad y descripción de cada uno de los procesos y actividades a ejecutar.

\section{Estructura}

El centro de acoplamiento cultural "Cubara" adoptara una estructura organizacional tipo funcional, planeación corporativa contiene misión, visión, objetivos, valores, estrategias, perfil de los cargos y sus funciones. Dentro de la parte legal se estableció que la empresa será S.A.S (sociedad por acciones simplificada), donde cada socio dará un aporte social de $\$ 12.000 .000$ de pesos para cubrir el total de gastos de inversión inicial.

Dentro del análisis financiero se determinó que en una proyección de 5 años, la empresa deriva una TIR de 171\%., un VPN de $\$ 279.608 .329$ una tasa mínima de rendimiento del 18\%; y un periodo de recuperación de $0.17 \%$ lo cual permite asegurar la viabilidad de la creación del Centro de acoplamiento cultural "CUBARA" en la ciudad de Tunja. 


\section{Contenido}

P.

Capítulo de Análisis del Mercado

Introducción

Titulo

Descripción de la Situación Actual

Descripción del Problema

Análisis de Causas y Efectos

Fuente. Autores

La Población Afectada

Zona ò Área de Influencia 
$\begin{array}{ll}\text { Justificación del Proyecto } & 26\end{array}$

$\begin{array}{lr}\text { Población Objetivo } & 28\end{array}$

$\begin{array}{ll}\text { Zona Beneficiada } & 28\end{array}$

$\begin{array}{ll}\text { Tipo de Proyecto } & 29\end{array}$

$\begin{array}{ll}\text { Resultados Esperados } & 29\end{array}$

$\begin{array}{lr}\text { Antecedentes } & 29\end{array}$

$\begin{array}{ll}\text { Estudio de Mercado } & 33\end{array}$

Marco Teórico y Conceptual 33

$\begin{array}{ll}\text { Metodología } & 34\end{array}$

Objetivos de la investigación de mercados 35

$\begin{array}{ll}\text { Objetivo general } & 35\end{array}$

Descripción de Producto y Servicio 35

$\begin{array}{ll}\text { Servicios } & 36\end{array}$

Bebidas a Base de Café $\quad 36$

$\begin{array}{ll}\text { Calientes Especiales } & 38\end{array}$

Bebidas Especiales de Café Frías $\quad 38$

Bebidas a Base de Té, Hierbas Aromáticas y Frutas 38

Hierbas Aromáticas e infusiones frutales $\quad 39$

Bebidas Alcohólicas y Fermentadas $\quad 40$

$\begin{array}{ll}\text { Análisis de la Demanda } & 40\end{array}$ 
Objetivo de Demanda

Análisis general de la encuesta

Determinación de la Demanda

Características Teóricas de la Demanda

Estimación de la Demanda Futura

Análisis de la Oferta

Objetivo de la Oferta

Metodología de la Oferta

Proveedores del Bien o Servicio, Análisis de Competencia

Régimen del Mercado

Régimen y Características del Mercado de los Insumos

Análisis de Sector

Características de la oferta

Marco teórico y conceptual

Tamaño del proyecto: volúmenes de producción y comercialización del bien o servicio proyectados 
Localización; Macro localización y Micro localización, Matriz de Planta Física

Macro Localización

Micro localización

Ingeniería del Proyecto

Descripción técnica del producto

Identificación y Selección de Procesos

Análisis de normas ISO aplicadas a los procesos

Análisis Ambiental

Marco teórico

Organización y Aspectos Administrativos

Marco teórico y conceptual de los aspectos administrativos y organizacionales

Metodología utilizada para la formulación de los aspectos administrativos yorganizacionales

Estructura orgánica y funciones a nivel de áreas

Área administrativa

Área de Producción y Servicio al Cliente

Área de Gestión Cultural 
Función de recursos humanos: sistemas de reclutamiento, remuneración, desarrollo, bienestar social, y relaciones laborales.

Contratación

Tipo de contrato manejado

Función de mercadeo: el plan de mercados, sistemas de divulgación y promoción del bien o servicio, sistema de ventas

Función de servicios administrativos: seguridad y mantenimiento de instalaciones

Función financiera: sistemas de contabilidad y presupuestos, políticas de financiamiento e inversiones

Pautas para garantizar la sostenibilidad del proyecto una vez entre en operación. 
Metodología del estudio financiero

Presupuesto de inversiones: inversiones fijas, capital de trabajo, fuentes de financiamiento 108

Costos de producción: costos de fabricación, gastos administrativos, otros gastos indirectos.

Ingresos y flujo de producción.

Balance de inicio del proyecto.

Flujo de fondos del proyecto: flujo neto de caja, flujo de financiación, flujo con y sin financiación, flujo incremental.

Conclusiones

Recomendaciones 


\section{Lista de Figuras}

Figura 4. ¿Le gustaría que en la ciudad de Tunja, existiera un espacio donde la cultura y el café se unieran?

Figura 5. ¿Conoce usted la existencia de un café cultural en la ciudad de Tunja?

Figura 6. ¿Participaría en las distintas actividades culturales que se desarrollen en un café cultural?

Figura 7. ¿De qué manera participaría en las diferentes actividades culturales?

Figura 8. ¿Cuánto estaría dispuesto a invertir por el servicio dentro de un café-bar donde se realicen actividades culturales?

Figura9. ¿Cuándo usted sale a un café-bar que le es más conveniente?

Figura 10. ¿Qué es lo más importante para usted dentro de un café-bar?

Figura 11. ¿Qué le gustaría encontrar en un café cultural?

Figura 12. ¿Qué actividades le gustaría encontrar en el café cultural?

Figura 13. Escoja de las siguientes actividades culturales cual es la más importante para usted. 
Figura 14. ¿Con que frecuencia a la semana visita usted un café-bar? 48

Figura 15. ¿Para usted en qué lugar le gustaría que este ubicado el café cultural?

Figura 20. Proceso de localización.

Figura 22. Flujograma de elaboración de bebidas.

Figura 25. Sistema de gestión medioambiental.

Figura 26. Organigrama. 


\section{Lista de Tablas}

P.

Tabla 1. Proyección de población estudiantil en Tunja. 28

Tabla 2.Proyección poblacional de Tunja. $\quad 50$

Tabla 3. Proyección de la población de Tunja entre los 18 a 35 años.

Tabla 4. Proyección estudiantil de Tunja. 51

Tabla 5.Ingresos y gastos de Tunja. 53

Tabla 7. Demanda futura.

$\begin{array}{lr}\text { Tabla 8.Proyección de la oferta. } & 60\end{array}$

Tabla 9. Demanda Vs Oferta.

$\begin{array}{ll}\text { Tabla 10.Función de precios. } & 61\end{array}$

Tabla 11.Disponibilidad de insumos públicos. 63

Tabla 12. Disponibilidad de servicios públicos 64

Tabla 13. Descripción de insumos 76

Tabla 14.Planta de cargos requerida.

Tabla 15.Descripción de funciones y perfiles a nivel de cargo.

$\begin{array}{lr}\text { Tabla 16.Nomina Contable. } & 88\end{array}$

$\begin{array}{lr}\text { Tabla 17.Inversiones Fijas. } & 108\end{array}$

$\begin{array}{lr}\text { Tabla 18.Gastos anuales de administración. } & 109\end{array}$

$\begin{array}{lr}\text { Tabla 19.Capital de trabajo. } & 109\end{array}$ 
Tabla 20.Costos anuales de fabricación.

Tabla 21.Gastos Anuales de administración.

Tabla 22.Otros Gastos Indirectos.

Tabla 23.Ingresos y flujo de producción.

Tabla 24.Balance de Inicio.

Tabla 25. Flujo de fondos del proyecto.

Tabla 26.Cálculos de indicadores. 


\section{Lista de Anexos}

P.

Anexo 1 EncuestaCentro de Encuentro Cultural

119

Anexo 2. Encuesta por internet

Anexo 3. Registro único tributario

Anexo 4. Cámara de comercio

124

Anexo 5. Logo

126 


\section{Introducción}

En Colombia debido a la situación económica que vivimos hoy en día, es indispensable que los profesionales enfoquen todos sus esfuerzos hacia la generación de empleo, con el propósito de contribuir no solo al mejoramiento de su calidad de vida, sino al de toda una comunidad, durante el desarrollo de este trabajo se podrán observar todo los requerimientos utilizados para la apertura de un café cultural además; explica la necesidad de estos espacios culturales como una forma de alejar a los jóvenes de los problemas que presenta la sociedad tales como alcoholismo y drogadicción.

En Tunja se hace necesario abrir un café cultural ya que hay muchos artistas pero pocos son los espacios que tienen para dar a conocer su arte, observado como un estilo de vida brinda estabilidad emocional y espiritual en el ser humano, da la oportunidad de encontrarse consigo mismo, facilitando la relación con las persona, permitiendo un mejor ambiente social, las personas que al arte se dedican demuestran viven una vida más tranquila, saludable y son mejores analistas para la toma de decisiones.

Con la apertura del café cultural se quiere abrir la mente de las personas, cambiar la forma de pensar de estas, frente al arte y a los artistas. 


\section{Titulo}

Plan de Negocios para la Creación de un Centro de Acoplamiento "Café y Cultura" en la Ciudad de Tunja.

\section{Descripción de la Situación Actual}

\section{Descripción del Problema}

La ciudad de Tunja en los últimos años ha presentado un crecimiento urbano y demográfico que nos permite a nosotros como ciudadanos enfrentar una serie de cambios que abarcan la parte social y cultural de nuestra región. Todo esto atrae un conjunto de ideas innovadoras que hacen que adoptemos un estilo de vida másapropiado con la globalización, partiendo de aquellas en las que se ve comprometido el pensamiento y las necesidades que hoy en día son requeridas por jóvenes, niños y adultos.

Como ya sabemos Tunja es considerada una ciudad universitaria ya que es un punto de integración y opción de vida para los jóvenes o adultos que apenas entran en el mundo universitario, pues esta ofrece un estilo de vida tranquilo y poco costoso, por esta razón es necesario ir a la par con el crecimiento que la ciudad presenta creando nuevas ideas que aporten al desarrollo cultural y social de la misma.

Si no se ofrecen diferentes alternativas de distracción o formas de emplear el tiempo haciendo algo relativamente útil, muchos de los jóvenes y adultos terminan gastando su tiempo libre en las drogas y el alcohol, logrando un estancamiento de su desarrollo personal y social o simplemente no encuentran esos escapes aumentando sus niveles de estrés, produciendo enfermedades que no permitenel desarrollo de una vida sana. 


\section{Análisis de Causas y Efectos}

Al hacer un análisis de los diferentes espacios de entretenimiento y relajación que tiene Tunja, nos damos cuenta que no son suficientes, ni cumplen con las expectativas que un ciudadano promedio desea, no brindan el espacio suficiente como para no caer en la rutina a la que nos puede llevar la ciudad. Partiendo de esto se desea retomar un poco de conciencia urbana, social y humanista a partir de la creación de un café cultural que ofrezca distintas actividades proporcionales a los gustos y demanda de la sociedad, generando un ambiente de plenitud y satisfacción mental a los clientes por medio de encuentros culturales de artistas regionales dedicados a la poesía, música, fotografía, teatro, danzas y artes plásticas, permitiendo que el cliente tenga un contacto más objetivo con el arte y encuentre sus raíces, sus orígenes, una forma de vida; desde los productos que elaboramos hasta el servicio que se presta con el fin de que se obtenga una recopilación de conocimiento hecho cultura. 
Figura 1. El Árbol de Medios Fines

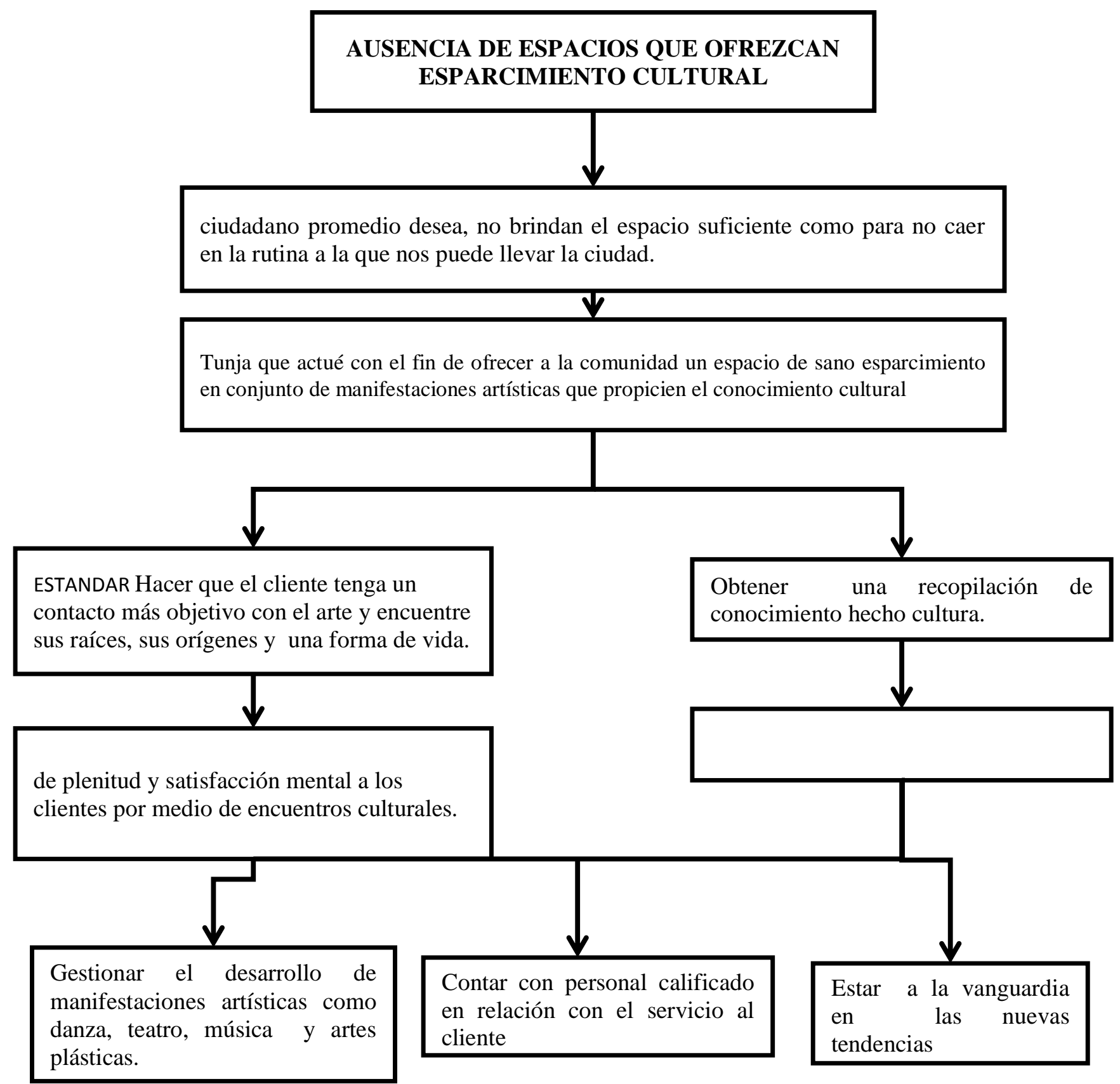

Fuente. Autores

\section{La Población Afectada}

Estará enfocado principalmente a jóvenes estudiantes universitarios entre las edades de 18 a 35 años, que no tiene alternativas para de ocupar su tiempo libre, en lo que termina en 
consumo de drogas y alcohol, logrando un malestar en los jóvenes además de disminuir el tiempo que pueden utilizar en obtención de su conocimiento.

El café cultural será un lugar que brinde un cambio a la rutina, a las diferentes formas de vivir y percibir el arte, será una unión de culturas para todo tipo de edades; será la manera de ofrecer a la comunidad momentos de alegría y risas solo con pequeñas cosas, logrando así dar un giro a las costumbres, por momentos importantes y necesarios que hacen la diferencia en nuestra vida.

\section{Zona ò Área de Influencia}

La zona de influencia donde se desarrollara el plan de negocios es la ciudad de Tunja en el departamento de Boyacá, buscando incentivar la utilización del buen tiempo en los jóvenes, partiendo de espacios con manifestaciones culturales que permitan la relación de la cultura con el desenvolvimiento de acciones que propicien una vida estable sana y saludable en los participantes.

\section{Características Geográficas de la Región}

Tunja está a 125 kilómetros de Bogotá, recorriendo el altiplano y su bello paisaje, por la carretera que próximamente será de doble calzada, en un trayecto de un poco menos de dos horas de viaje. Tunja es la capital más alta de Colombia y por lo tanto una de la más frías. Su altura sobre el nivel del mar es de 2.775 metros. Su altura máxima es de 3.200 metros en límites con Cucaita y su altura mínima es de 2.400 metros sobre el nivel del mar, en límites con el municipio de Boyacá. La extensión territorial de Tunja es de 118 kilómetros cuadrados, de los cuales el $87 \%$ corresponde al área rural y el $13 \%$ al área urbana. Ubicada sobre la cordillera oriental, en una pequeña meseta rodeada por colinas en el occidente y el oriente, pero desprotegida por el sur y por el norte lo que permite que los vientos que la recorren la 
hagan más fría. "Caracterización socio-económica de Tunja"

La ubicación de la ciudad de Tunja es muy favorable para el desarrollo del proyecto ya que se encuentra a muy pocos kilómetros de distancia de municipios tales como Duitama y Sogamoso.

\section{Características Económicas, Sociales, Demográficas, de la Zona o Área de Influencia.}

Características demográficas. Tunja se ubica en las ciudades de tercer orden (población entre 100 mil y 500 mil habitantes), con un estimado actual de 177.971 habitantes. A su vez, se localiza en el área de influencia de Bogotá, dadas las relaciones económicas, sociales y demográficas que se han establecido, favorecidas por la cercanía entre estas dos ciudades $(120 \mathrm{~km})$. Según los datos presentados se puede afirmar que Tunja ha experimentado en los últimos años un aumento constante de su población. Con referencia al crecimiento demográfico de la ciudad, entre los años 1985 y 2005 se registró una tasa promedio de crecimiento de $0,13 \%$. Se espera que para el año 2020 esta cifra se reduzca a $0,09 \%$, hecho que estaría relacionado con indicadores como la natalidad y la migración. Los datos disponibles para el año 2011 indican que la ciudad registra una tasa de crecimiento natural del orden de $2.3 \%$, levemente superior a la registrada en Colombia (1.16\%) y en el departamento $(0,91 \%)$. La tasa de natalidad se ubica en un $32,8 \%$, mientras que la de mortalidad es de $8,9 \%$.

\section{Caracterización socio-económica de Tunja y de la región central.}

-Características Socio- Económicas. Según estudios realizados por la alcaldía mayor de Tunja se encuentra que el mayor crecimientoeconómico de la ciudad es en las actividades económicas del sector terciario.

"En referencia a la participación poblacional en las actividades o sectores económicos descritos, la Figura 2 señala la fuerza que a nivel general tiene el comercio, ocupando al 
menos a una de cada cuatro de las personas. En general el comportamiento del empleo es aproximadamente igual en las ciudades y regiones de comparación, a no ser en el sector de la industria y en las actividades de educación, en las que se presenta un cambio sustancial frente a las zonas de referencia.” (Caracterización socio-económica de Tunja)

Figura 2. Participación de los sectores según las unidades económicas.

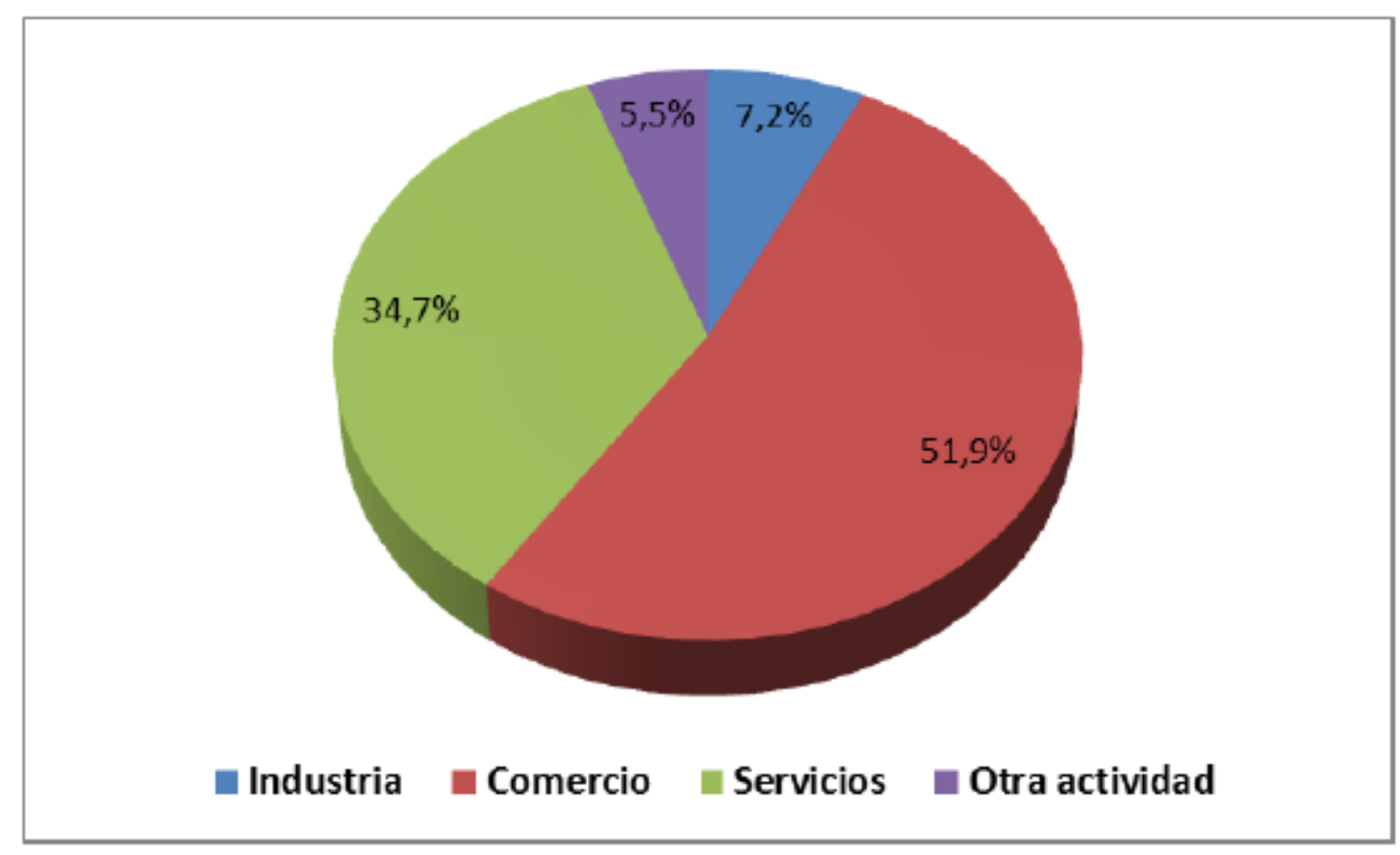

Fuente. Caracterización socio-económica de Tunja y de la región central pág. 30.

\section{DescripciónGeneral del Proyecto}

\section{Nombre del Proyecto}

Plan de Negocios para la Creación de un Centro de Acoplamiento "Café y Cultura" en la Ciudad de Tunja. 


\section{Objetivos}

Objetivo General. Desarrollar un plan de negocios para la creación de un Café cultural en la ciudad de Tunja que actué con el fin de ofrecer a la comunidad un espacio de sano esparcimiento en conjunto de manifestaciones artísticas que propicien el conocimiento cultural.

\section{Objetivos Específicos.}

- Realizar un estudio de mercadeo por medio de un análisis de datos que permita identificar las diferentes condiciones culturales, económicas y sociales para definir los diferentes hábitos, comportamientos, gustos, frecuencias y preferencias de la población, en materia de consumo y espectáculos artísticos para determinar pronósticos en cuanto al entorno del mercado.

- Encontrar la necesidad de la ciudad de Tunja por parte de artistas y espectadores, por medio de análisis de información, con el fin suplir al máximo la necesidad.

- Ejecutar un estudio técnico del café cultural en la ciudad de Tunja especificando la localización apropiada del lugar, el tamaño y la utilización de los recursos humanos, tecnológicos y financieros que se utilizan en el proyecto.

- Identificar metas, tareas, la razón social, objetivos por medio de lo que se quiere mostrar y dar la ciudad de Tunja con el fin de dar a conocer el servicio satisfactoriamente

- Analizar el marco legal que influencia la creación del Café Cultural en la ciudad de Tunja en sus diferentes nomenclaturas tales como los decretos o disposiciones legales (leyes, acuerdos, resoluciones y reglamentos) los cuales determinan las diferentes situaciones técnicas, financieras e institucionales que afectan la ejecución y desarrollo del proyecto. 
- Establecer el marco presupuestal del proyecto analizando las diferentes alternativas de financiación, con el fin de suplir los gastos y costos en los que se incurrirá el desarrollo de actividades comerciales, económicas y sociales del proyecto.

- Identificar los ingresos y egresos del café cultural por medio de cotizaciones y análisis de competidores con el fin de estudiar la factibilidad económica del establecimiento en la ciudad de Tunja.

- Planear un sistema de gestión ambiental estudiando los diferentes factores que influyen en la contaminación ambiental dentro del café, para disminuirlos al máximo.

\section{Agentes promotores, formuladores y responsables de la ejecución}

Los responsables y formuladores del proyecto son estudiantes de la Facultad de Administración de Empresas de la universidad Santo Tomas de Tunja, con la colaboración de los docentes de la misma facultad.

\section{Descripción general de la alternativa seleccionada}

El centro de acoplamiento cultural es una idea de negocio que brindara la oportunidad, a los estudiantes de ocupar su tiempo libre en actividades artísticas que le brinden conocimiento, pero sin cambiar la costumbre de tomar una café.

Beneficia los artistas de la ciudad de Tunja que dedican su vida a trabajar en las diferentes manifestaciones artísticas, ya sean artes escénicas o artes plásticas.

\section{Justificación del Proyecto}

Hoy en día asistir a una exposición artística es una necesidad emocional o comercial, tal vez las dos, esta es una herencia que con diferentes orígenes, como el religiosa, pedagógico, estético, social o comercial se ha compenetrado cada vez más en nuestras vidas como un espectáculo único en búsqueda de necesidades estéticas para su entorno, trasmitir los 
pensamientos de un movimiento a través de la obra de arte, ajustándola a su realidad, reconociendo la investigación que el artista ha recopilado, es ya una parte fundamental en la vida del individuo.

El vínculo entre el producto artístico y su contexto histórico da como resultado el conocimiento de la procedencia cultural de los pueblos, enriqueciéndose por medio de la contemplación artística en sus diferentes manifestaciones que han dejado de ser una muestra de deleite para unos pocos privilegiados, dando la oportunidad a todos los individuos presentándose una experiencia de humanización de los espacios compartidos a través de los recursos artísticos y sus relaciones con el contexto social, histórico, político y cultural en que se produce, haciendo énfasis en la creatividad y el análisis de la conducta, como puntos importantes para la base de la convivencia.

Las nuevas propuestas están centradas en determinar los vínculos que se establecen entre el arte y la cotidianidad, esta relación se origina en la búsqueda artística de lo nuevo, que hace que los artistas propongan novedosas y variadas creaciones, con diversas necesidades de escenarios inclusive los compartidos como es el caso de los parques, restaurantes, bares, medios de transporte, etc., para así canalizar muchas de las propuestas artísticas de interés general.

Considerando la forma de vida actual, existe una realidad imposible de desmentir que es la competitividad y globalización de los mercados, la necesidad de mantenerse actualizado en las nuevas tendencias de creación y actualización social nos involucran en ciertos ambientes que no nos permiten disfrutar de espacios que nos brinden tranquilidad, relajacióny algo de cultura a nuestras vidas encontrando diferentes maneras de satisfacción mental. 
Por medio de este proyecto se quiere demostrar que son necesarios ciertos espacios que les permitan a las personas abrir su mirada a otros puntos de vista y busquen otra manera de escapar del estrés que viven en su trabajo, en sus estudios o que les genera la misma rutina que tiene la ciudad. Además demostrar que el arte, mostrando este como la expresión del conocimiento, hace a las personas despertar una serie de emociones, que les permite encontrar diferentes formas de motivación.

Con la idea de crear un café cultural se busca ofrecer un espacio acogedor, permitiendo a los jóvenes romper con la rutina cotidiana, con las diferentes manifestaciones artísticas, como exposiciones de fotografía, pintura, obras de teatro, cine foros, poesía entre otras, que les sirva como una herramienta de conocimiento cultural, y se conviertan en personas criticas frente a problemáticas actuales. Además que hagan parte de pequeños proyectos artísticos.

\section{Población Objetivo}

La población objetivo es la población estudiantil universitaria entre los 18 a 35 años de edad, de la ciudad de Tunja.

\section{Tabla 1.}

Proyección de población estudiantil en Tunja.

\begin{tabular}{lcccccccc}
\hline Año & $\mathbf{2 0 1 3}$ & $\mathbf{2 0 1 4}$ & $\mathbf{2 0 1 5}$ & $\mathbf{2 0 1 6}$ & $\mathbf{2 0 1 7}$ & $\mathbf{2 0 1 8}$ & $\mathbf{2 0 1 9}$ & $\mathbf{2 0 2 0}$ \\
\hline $\begin{array}{l}\text { Población } \\
\text { Estudiantil }\end{array}$ & 21903 & 22163 & 22425 & 22691 & 22960 & 23233 & 23508 & 23787 \\
\hline Fuente. Dane Proyección de la población & & & & & &
\end{tabular}

Fuente. Dane Proyección de la población

\section{Zona Beneficiada}

La zona beneficiada es la ciudad de Tunja principalmente los artistas del municipio, ya que les permite mostrar su arte en los diferentes eventos organizados por el café, ya sea teatro, música, artes plásticas, cine y diferentes propuestas artísticas que se presenten. 


\section{Tipo de Proyecto}

El proyecto de plan de negocios para la creación de un centro de acoplamiento cultural, es de tipo descriptivo, ya que este se delimita a hechos que llevan a un estudio administrativo, técnico, financiero, de mercados y legal.

Una razón de porque es una investigación descriptiva es porque se elabora una etapa de observación, análisis de datos por medio de encuestas; sin la necesidad de manipular el entorno.

\section{Resultados Esperados}

Los resultados esperados es cumplir a cabalidad con los objetivos propuestos en cada una de los estudios, para determinar la factibilidad de un centro de acopio cultural en la ciudad de Tunja.

\section{Antecedentes}

"Hoy en día el arte se considera, en todas sus categorías, como parte fundamental de los logros de la humanidad", y la cultura es fundamental en el desarrollo de los pueblos. (Red Colombia de Teatro).

A través de la historia todos diferentes filósofos, escritores y artistas hablan de la importancia del arte en el ser humano, para formar personas integras que permitan vivir en comunidad, según:

Aristóteles al tratar sobre la música en su política, mantiene que el arte afecta al carácter humano, y por lo tanto al orden social. Puesto que Aristóteles sostenía que la felicidad es el destino de la vida, creía que la principal función del arte es proporcionar satisfacción a los hombres. 
Johann Gottlieb Fichte, el arte es individual o social, aunque satisface un importante propósito humano.

Nietzsche estaba de acuerdo con que la vida es trágica, pero esa idea no debería excluir la aceptación de lo trágico con alegre espíritu, pues su realización plena es el arte, el cual se enfrenta con los terrores del universo a los que se puede transformar, generando cualquier experiencia en algo bello, y al hacerlo así transforma las angustias del mundo de tal modo que pueden ser contemplados con el placer.

En la estética tradicional se ha asumido también con alguna frecuencia que las obras de arte son tan útiles como bellas, "los cuadros podían conmemorar eventos históricos o estimular la moral. La música podía inspirar piedad o patriotismo" o en el caso particular del teatro, puede servir para criticar la sociedad y de ese modo ser útil para reformarla. (Alejandro Dumas y el noruego Henri Ibsen, en un periodo complejo de la sociedad)

Henri Bergson plantea, que el arte, sin embargo, se base en instituciones, lo que es una aprehensión directa de la realidad no interferida por el pensamiento. Así, el arte se abre el camino mediante los símbolos y creencias convenciones acerca de la gente, la vida y la sociedad y enfrenta al individuo con la realidad misma.

Benedetto Croce las obras de arte son la expresión en forma material de tales instituciones; belleza y fealdad, no obstante, no son rasgos de las arte sino cualidades del espíritu expresadas por la vía intuitiva en la misma obra de arte.

El marxismo trata el arte como una expresión de las relaciones económicas subyacentes en la sociedad, y mantiene que el arte solo es importante solo cuando es progresista es decir, cuando defiende los valores de la sociedad en la cual se crea. Por su parte Sigmund Freud creía en el valor en el valor del arte para usarlo como forma terapéutica: es por este medio que 
tanto el artista como el público pueden revelar conflictos profundos y descargar tensiones. Fantasías y en sueños. Al intervenir en el arte son transformados de este modo desde un escape psicológico hasta planear diversas formas de concebir la vida

Observar la función del arte a través del tiempo, se encuentra que no solo es una necesidad de cada persona, también es una necesidad de una comunidad para demostrar un sentimiento de desahogo para los diferentes conflictos sociales ya sean políticos, laborales, religiosos, inconformismo por la nuevas tendencias, personales o hasta la misma rutina, que se vuelve el diario vivir de las personas. Por eso mismo el arte ya no es cuestión de una exposición en un museo o una obra en un teatro, con un alto precio; a pasar del tiempo se convirtió en una distracción en la que podía participar personas de todo tipo, ya que muchos espacios se fueron convirtiendo, en escenarios para manifestaciones artísticas, como parques, restaurantes, bares, medios de transporte, plazas públicas, dando nuevas formas e instituciones de interacción con el arte.

Café cultural: cuna de los clubes y de las capillas, el café es según León Paul Farguela academia de el señor don fulano, el centro del universo al alcance de todos. (Alianza colombo francesa, 2004).

Los cafés literarios "son lugares privilegiados en los que tanto el político como el director de empresa, el periodista como el conspirador, el escritor como el artista, el poeta como el músico comentan la canción de la ciudad" (Alianza colombo francesa, 2004). Sitio celebre que reúne tertulias que impulsan la actividad intelectual de un país. Allí se estudia la historia, literatura, política, arte, se componen discursos estimulados por premios de honor (Rodríguez, 1991). 
Tertulia: Es una reunión que se hace con regularidad para conversar y pensar sobre un tema que interesa a quienes participan en ella. Hay tertulias de toda clase desde las que se dedican a discutir sobre literatura, política, filosofía, arte o ciencia hasta las que se desarrollan en torno a temas particulares (Fundalectura, 2004).

Hace referencia a encuentros informales entre gente de letras en los que se habla sobre arte, literatura y política. Vinculadas normalmente a acontecimientos históricos y artísticos, las tertulias sirven muchas veces como pretexto de conspiración política, como fragua de ideas, como estímulo de proyectos de renovación estética, como centros donde se conforman nuevos movimientos literarios (Rodríguez, 1991).

Cultura: resultado de cultivar los conocimientos humanos e inmateriales de que cada sociedad dispone para relacionarse con el medio y establecer formas de comunicación entre los propios individuos o grupo de individuos (ENCAS, 1999).

El término cultura engloba además modos de vida, ceremonias, arte, invenciones, tecnología, sistemas de valores, derechos fundamentales del ser humano, tradiciones y creencias. A través de la cultura se expresa el hombre, toma conciencia de sí mismo, cuestiona sus realizaciones, busca nuevos significados y crea obras que le trascienden (Enciclopedia Superior, 2000).

Arte: actividad que requiere un aprendizaje y puede limitarse a una simple habilidad técnica o ampliarse hasta el punto de englobar la expresión de una visión particular del mundo. El término arte deriva del latín ars, que significa habilidad y hace referencia a la realización de acciones que requieren una especialización. Es la actividad espiritual por medio de la cual crea al hombre obras con el fin de embellecerlas (Ayuso, 1997). 
Sin embargo, en un sentido más amplio, el concepto hace referencia tanto a la habilidad técnica como al talento creativo en un contexto musical, literario, visual o de puesta en escena. El arte procura a la persona o personas que lo practican y a quienes lo observan una experiencia que puede ser de orden estético, emocional, intelectual o bien combinar todas esas cualidades (Enciclopedia Superior, 2000).

Literatura: Conjunto de obras orales y escritas cuya finalidad es la plasmación estética, es decir, que trasciende el criterio de finalidad comunicativa práctica (Reyzábal, 1998). El arte que usa como instrumento la palabra (Ayuso, 1997).

Conjunto de todas las producciones literarias de un pueblo o de una época; el mundo de las letra y de los escritores; el arte de escribir (Ayuso, 1997)

\section{Estudio de Mercado}

\section{Marco Teórico y Conceptual}

Un estudio de mercado se identifica con la definición de precio a que los consumidores estén dispuestos a comprar y la demanda.

Un estudio de mercado es más que un análisis y determinación de la oferta y la demanda de los precios del proyecto, muchos costos de operación pueden preverse simulando la situación futura y especificando las políticas y procedimientos que se utilizaran como estrategia comercial. Él mismo análisis puede realizarse para explicar la política de distribución del producto final.

Al estudiar un mercado de un proyecto es preciso reconocer todos los agentes que con su actuación tendrán algún grado de influencia sobre las decisiones que se tomaran al definir su estrategia comercial; al analizar el consumidor se debe tener en cuenta los hábitos de consumo las preferencias, las motivaciones para obtener un perfil sobre la cual se pueda basar la 
estrategia comercial, el estudio de la demanda pretende cuantificar el volumen de los bienes o servicios que el consumidor podría adquirir de la producción del proyecto, el estudio de la competencia es fundamental para conocer las estrategias que sigue la competencia, observar ventajas y evitar las desventajas y el mercado de los proveedores puede llegar a ser determinante en el éxito o fracaso de un proyecto de ahí la necesidad de estudiar insumos requeridos y cuál es el precio que debería pagarse para garantizar su abastecimiento.

El centro de acoplamiento cultural busca diferenciarse de los demás cafés en la ciudad de Tunja, gracias a aspectos como la calidad en el servicio y la gran variedad de presentaciones y espectáculos que desean introducirse dando así un lugar donde exista la relación entre calidad y precio.

La creación de un centro de acoplamiento surge de la idea de promover e incentivar a la población de Tunja a conocer su cultura y sus manifestaciones en diferentes espacios, brindando así un momento de placer y tranquilidad acompañado de un lugar que se acople a las necesidades Tunjanas. Esto es lo que hace la diferencia frente a los competidores, rompiendo con los esquemas que se vienen manejando en la ciudad de Tunja valiéndose de fuertes atractivos y características de público en general. (Preparación y evaluación de proyectos, cuarta edición)

\section{Metodología}

El estudio de mercados para un proyecto es una etapa que nos permite analizar el comportamiento del mercado en cuanto a gustos de los consumidores, el comportamiento del mercado de nuestros competidores, y otros aspectos influyentes en la conformación de nuestra estrategia comercial. 
La manera como comenzaremos este estudio de mercado es describiendo nuestro producto y servicio, luego por medio de encuestas se analizaran las costumbres, hábitos y motivaciones de nuestros posibles consumidores; por ultimo terminaremos con el análisis de la capacidad de los clientes para adquirir nuestro producto y servicio.

\section{Objetivos de la investigación de mercados}

Objetivo general. Estudiar los comportamientos de los consumidores, la competencia, los canales de distribución y los diferentes proveedores por medio de encuestas y trabajo de campo para definir la estrategia comercial conformada por la gestión cultural y todas las actividades pertinentes al café.

\section{Objetivos específicos}

- Estudiar los comportamientos y motivaciones que influyen en toma de decisiones; a su vez la demanda para analizar la capacidad adquisitiva de los consumidores.

- Observar cómo se comporta el mercado con nuestros competidores con el fin de encontrar las ventajas y estar prevenidos en cuanto a las desventajas.

- Definir los diferentes proveedores, sus canales de distribución y la calidad de sus productos y servicios.

\section{Descripción de Producto y Servicio}

El centro de acoplamiento cultural se encuentra en el tercer nivel de los sectores económicos, en el cual se encuentra todos los bienes y servicios intangibles que no son productivos pero que contribuyen en la economía nacional.

El centro cultural está dirigido principalmente a estudiantes universitarios, y personas que trabajen o vivan en el sector centro que tengan de costumbre tomar una bebida, les guste o sean amantes del arte en todas sus manifestaciones, como artista o como espectador. 
El servicio del centro de acoplamiento cultural ofrece dos tipos de servicios el servicio de café -bar y la promoción de artistas e artes escénicas y en artes plásticas esto con el fin de dar un valor agregado al servicio de café incentivando a la población tunjana a conocer sobre su cultura.

Dentro del servicio de café bar se ofrecen principalmente productos como bebidas a base de café, té, hierbas aromáticas y frutas, licores y una pequeña sección de pasabocas y postres como acompañantes.

\section{Servicios}

Teatro: Es una representación por medio de la actuación en la cual se combinan gestos, discursos, escenografía música entre otros; de historias y costumbres, ante un público determinado hace parte de las artes escénicas.

Danza: Hace parte de las artes escénicas, Se utiliza como forma de comunicación donde los bailarines demuestran sentimientos y emociones, formas de interacción social; por medio del movimiento del cuerpo.

Música en vivo: Es una rama de las artes escénicas que logra combinar una serie de sonidos por medios de instrumentos y la voz de algunas personas permiten, representar sentimientos y emociones en los artistas como en los espectadores.

\section{Bebidas a Base de Café}

Elcafé es una bebida elaborada de una semilla que sale de la fruta de la planta del cafeto, originada en arabia, que con la llegada de los españoles a américa fueron cultivando las semillas en américa del sur en Colombia y Brasil los cuales son los mayores productores de café en el mundo; el cafeto tiene dos semillas una llamada Robusta la cual se caracteriza por su forma plana, contiene más cafeína, ofrece un sabor más fuerte y duplica la producción 
generalmente se produce en Brasil, la segunda semilla del cafeto es la Arábiga la cual tiene una forma ovalada, su sabor es de ácido a dulce y balanceado, produce aroma intensa, su producción es más costosa porque es susceptible a enfermedades, y es la semilla que se produce en Colombia.

Su sabor es fuerte tiende hacer amargo o acido, se dice que reconforta el ánimo de las personas, quita la sed, es una bebida muy apetecida en todo el mundo y es beneficiosa para los enfermedades de la vesícula ya que es diurética, ayuda el estreñimiento y algunas personas lo utilidad

Las bebidas a base de café que se ofrecen durante el servicio de café bar son:

Bebidas calientes.

Café expreso: es una bebida caliente corta, concentrada y aromática intensa, elaborada con 7 gramos de café en $100 \mathrm{~cm} 3$ de agua, el cual debe ser tipo gourmet en una máquina de expreso con una presión de 9.5 bares y una temperatura entre $88^{\circ}$ y $90^{\circ}$ centígrados.

Café americano: es una bebida caliente elaborada con un expreso y con agua caliente, se puede endulzar con panela, azúcar o miel.

Capuchino:bebida caliente compuesta por un expreso y $150 \mathrm{~cm} 3$ de leche espumosa a $60^{\circ}$ centígrados. Se sirve en pocillos de $250 \mathrm{~cm} 3$

Café Latte: es una bebida caliente la cual se elabora con un café expreso y leche caliente a temperatura entre $80^{\circ} \mathrm{c}$. Se sirve en pocillos de $250 \mathrm{~cm} 3$

Capuchino con Licor: bebida elabora con tres clases de licor puede ser crema de whisky, ron, whisky o brandy el cual se debe espumar, luego se le agrega el expreso y por ultimo leche espumada. Se sirve en pocillos de $250 \mathrm{~cm} 3$ 
Mocachino: se calienta la salsa de chocolate se le agrega un expreso y por ultimo leche espumada. Se sirve en pocillos de $250 \mathrm{~cm} 3$.

\section{Calientes Especiales}

Café Gelato:café expreso con helado de cualquier sabor preferible de vainilla.

IrishCoffe: se calienta el whiskey se le agrega agua caliente mientras tanto en una coctelera se agrega crema de leche, azúcar y un expreso se mesclas y se sirven sobre el whiskey

\section{Bebidas Especiales de Café Frías}

Expreso Correcto: en una copa se vierte hielo y un licor puede ser whiskey, brandy o ron y se le agrega hielo. Para decorar se puede con hojas de hierba buena.

Capuchino helado: se mezcla el expreso con la leche condensada, luego crema de leche, leche y unas gotas de extracto de vainilla y se sirve sobre hielo.

\section{Bebidas a Base de Té, Hierbas Aromáticas y Frutas}

Es una infusión de las hojas y brotes de la planta del té Camelia sinensis, es una bebida generalmente amarga se encuentra en diferentes panta de las cuales sale el té blanco, te rojo y los más utilizados él té vender y él te negro. Hay personas que argumentan que el té tiene bastantes beneficios para el organismo como estimula las defensas, combate la hipertensión, frena el envejecimiento, tonifica el cuerpo y la mente, previene la gripe y las enfermedades cardiovasculares y protege en contra del cáncer.

Él te toma de muchas maneras su puede tomar frio o caliente, el té verde es una infusión clara y de sabor suave, mientras el té negro su color es oscura parecida al café y tiene un sabor amargo. 
Te: infusiones de té verde y té negro calientes puede ser en agua o en leche.

Te frio: se elabora la infusión puede ser de té negro o té verde fuerte, se espera a que se enfrié, y se mantiene en el refrigerador en un recipiente tapado para evitar que el té se oxide, al momento de servir se agrega en la licuadora la infusión un poco de azúcar hielo, algunas gotas de limón o esencias frutales se mescla se sirve y se decora con rodajas de limón o hojas de hierba buena.

\section{Hierbas Aromáticas e infusiones frutales}

Aromática de hierbas: se elabora con agua caliente entre $88^{\circ}$ y $90^{\circ}$ grados centígrados, se le agrega flores de manzanilla. Hierba buena, flor de Jamaica, limonaria y en algunos caso mora para que de una sabor frutal, se deja reposar por unos segundos mientras toma sabor y se sirve.

Aromáticas de frutas: se elabora dejando cocinar la fruta que se desea en el café se ofrecerá uchuva, piña, fresa y papayuela (puede ser mixta) en un poco de agua y canela para el aroma hasta que llega a un punto de ebullición, y se sirve. Se sirve en pocillos de $250 \mathrm{~cm} 3$.

Jugos de fruta: se mezcla en la licuadora de acuerdo al gusto leche o agua, con la fruta que se desea, un poco de azúcar, hielo y sirve.

Además de estos productos ya nombrados se ofrecerá una bebida para niños en caso de que estén con sus padres que son:

Chocolate fantasía: se calienta leche se mezcla con un poco de chocolate en polvo y en el momento de servir se decora con másmelos de colores.

Chocolate frio: se mezcla en una licuadora leche y chocolate en polvo y un poco de hielo. 


\section{Bebidas Alcohólicas y Fermentadas}

Vinos. El vino es una bebida que sale de la fermentación alcohólica del zumo de la uva, por medio de la acción metabólica de las levaduras, se dice que aporta positivamente a las funciones, cardiacas, musculares y Oseas.

En el centro cultural se ofrece vino blanco y tinto de las diferentes clases Merlot, Cabernet Sauvignon, Malbec, entre otras clases. Además de vino al clima y caliente, además ofreceremos un vino de la casa elaborado con frutas, se sirve al clima.

Cerveza. Es una bebida alcohólica no destilada elaborada con los granos de cebada y varios cereales. Dentro del café se ofrece cerveza roja, rubia y negra, de tipo artesanal.

\section{Análisis de la Demanda}

Objetivo de Demanda. Estudiar el comportamiento actual del mercado, en la ciudad de Tunja en el sector del centro y Maldonado, además de realizar proyecciones futuras, para determinar precios y capacidad adquisitiva de nuestros consumidores.

\section{Diseño Metodológico}

La demanda se determina con diferentes variables como son proyección de la población, muestras poblacionales, precios de los consumidores, determinación de ingresos y gastos las cuales utilizaremos para determinar la demanda del plan de negocios de un centro cultural.

La forma de recolección utilizada para el proyecto fue analizar el tamaño de la muestra para desarrollar encuestas, visitas a nuestros consumidores y a las instituciones universitarias y consultas en páginas web como la del departamento administrativo nacional de estadística Dane.

Enfoque de la Investigación. Para la determinación de la demanda se va a utilizar el enfoque cuantitativo de investigación, la que permite la recolección de datos numéricos de 
tendencias y comportamientos de la población objetivo que se va a estudiar; el tipo de la investigación es descriptivo con un muestro no probabilístico ya que no todas las personas de la ciudad de Tunja tienen la probabilidad de ser encuestados, según esto el tipo de muestro utilizado es de intención o conveniencia, ya que se quiere llegar a una población estudiantil entre los 18 y 35 años de edad.

El instrumento utilizado para la recolección de datos es una encuesta aplicada a la población objetivo, realizada por internet a través de Google Drive Formularios, donde se crea un link para enviar a las personas que se quiere llegar, a través de las diferentes redes sociales; con el fin determinar gustos, necesidades, horarios en los que visitan los cafés y otros aspectos que contribuyan en el estudio.

Tamaño de la muestra. La muestra utilizada fue de tipo cuantitativo, probabilístico donde se obtienen muestras finitas, utilizando como elemento de recolección, una encuesta realizada por internet, por medio del programa de Google Drive formularios, Para obtener la muestra poblacional se tuvo en cuenta los siguientes aspectos: $\mathbf{N}=$ igual al tamaño de la muestra que 21903 el total de población estudiantil universitaria.

$\mathbf{e}=$ que es igual error de estimación del $5 \%$.

$\mathrm{S}=$ Desviación estándar del 0.5.

$\mathrm{Z}=$ margen de confiabilidad de $95 \%$

Para encontrar el tamaño de la muestra se despeja la siguiente fórmula:

$$
n=\frac{Z^{2} S^{2}}{e^{2}}
$$

Fuente.NassirSapagChain. Preparación y evaluación de proyectos, cuarta edición pág. 85. 


$$
\begin{gathered}
\mathrm{n}=\frac{21903 *(0.5)^{2} *(1.96)^{2}}{\left((21903-1) *(0.05)^{2}+\left((0.5)^{2} *(1.95)^{2}\right)\right)} \\
n=378
\end{gathered}
$$

Lo que concluye con una muestra de 378 personas para realizar la encuesta.

Resultados de la encuesta. La encuesta fue realizada por internet por medio de Google drive formularios a estudiantes universitarios de la ciudad de Tunja, entre los 18 a 35 años de edad. El objetivo de la encuesta es determinar la factibilidad de un centro de acoplamiento, a través de un café cultural, por medio del estudio de gustos, preferencias, productos y servicios que en el café desea encontrar.

Figura 3. Genero.

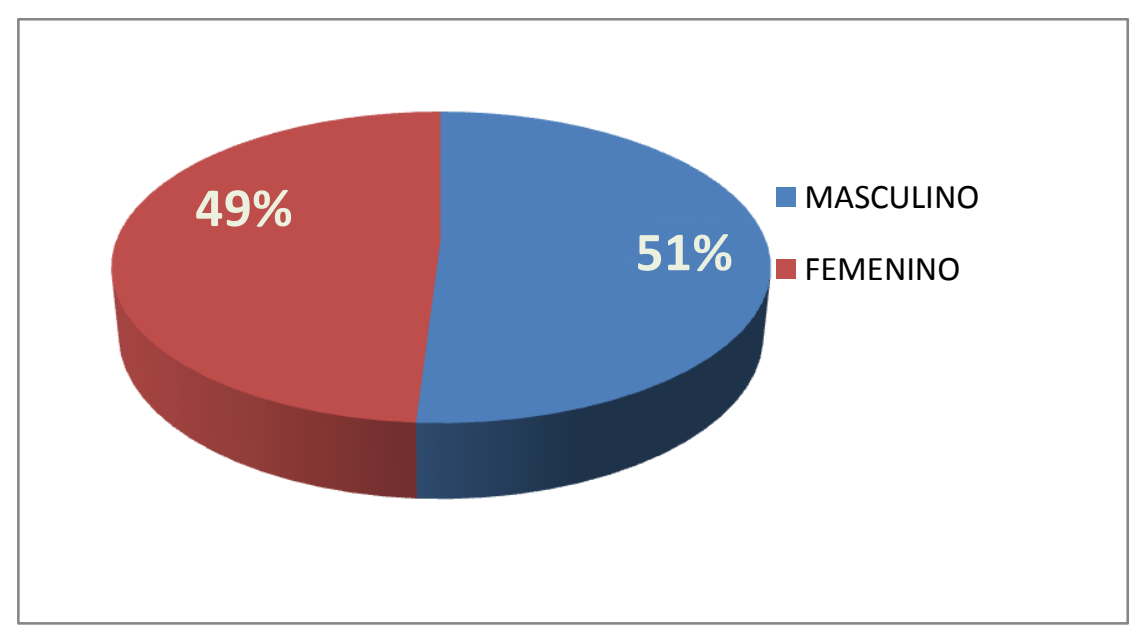

Fuente. Autoras.

De las 378 personas encuestadas el $49 \%$ corresponde al sexo femenino y el $51 \%$ al sexo masculino lo que indica que la idea de negocio les gusta tanto a hombres como a mujeres. 
Figura 4. ¿Le gustaría que en la ciudad de Tunja, existiera un espacio donde la cultura y el café se unieran?
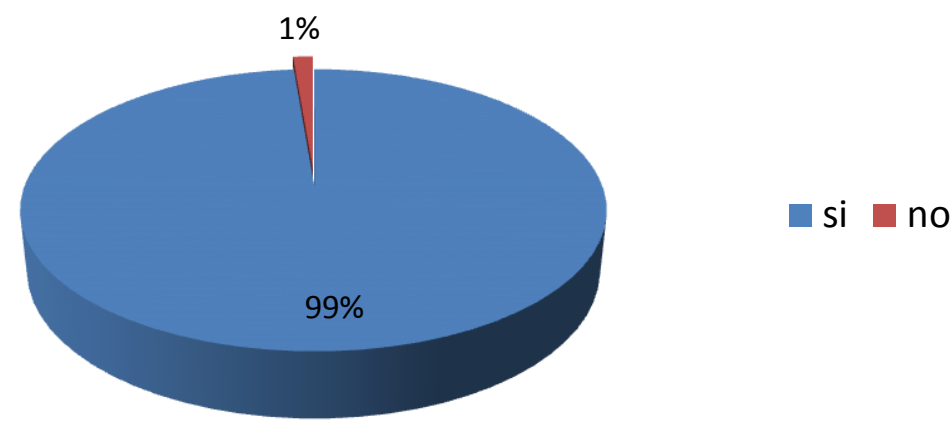

Fuente. Autoras.

El fin de esta pregunta era encontrar el porcentaje de personas a las que les gustaría la idea de una centro de acoplamiento cultural lo cual fue un porcentaje de $99 \%$ frente al $1 \%$, que les gustaría fue el primer filtro para encontrar ciertas tendencias en la cultura, de la ciudad de Tunja.

Figura 5. ¿Conoce usted la existencia de un café cultural en la ciudad de Tunja?

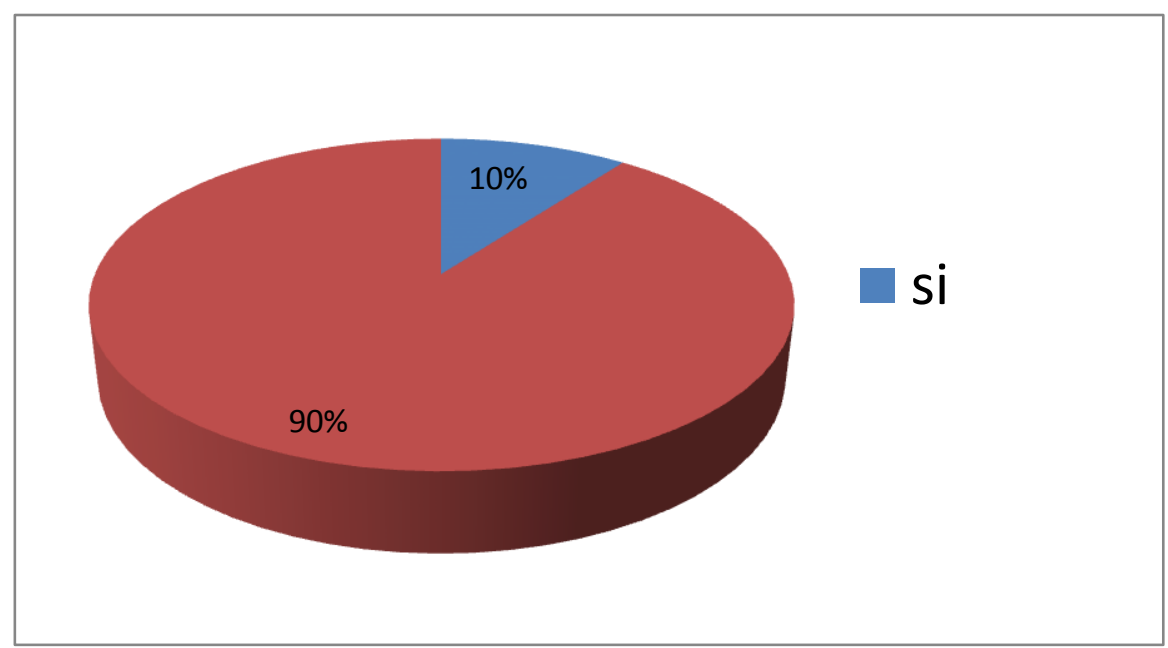

Fuente. Autoras. 
El $90 \%$ de las personas encuestadas no conocen la existencia de un café cultural en la ciudad de Tunja, mientras que un 10\% conocen "Clandestino Café-libro" siendo este nuestra competencia directa.

Figura 6. ¿Participaría en las distintas actividades culturales que se desarrollen en un café cultural?

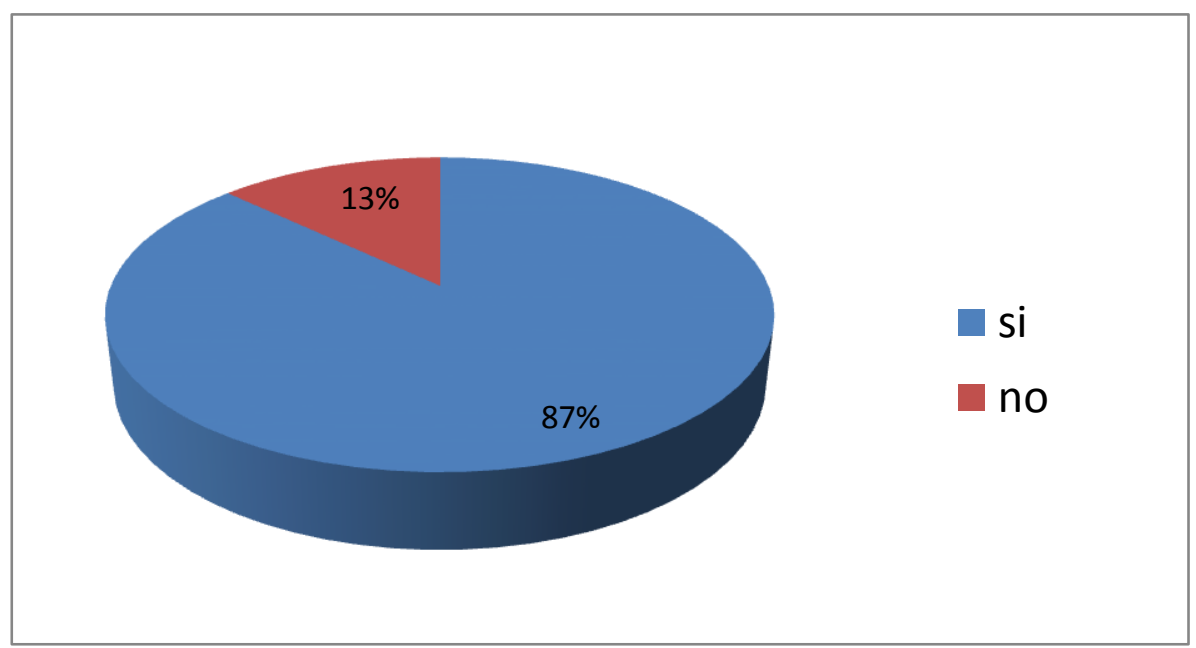

Fuente. Autoras.

El $87 \%$ de las personas encuestadas respondieron que si participarían en las diferentes actividades que se desarrollarían en un Café Cultural, mientras que un $13 \%$ no lo harían; lo cual nos indica que la idea de negocio es viable.

Figura 7. ¿De qué manera participaría en las diferentes actividades culturales?

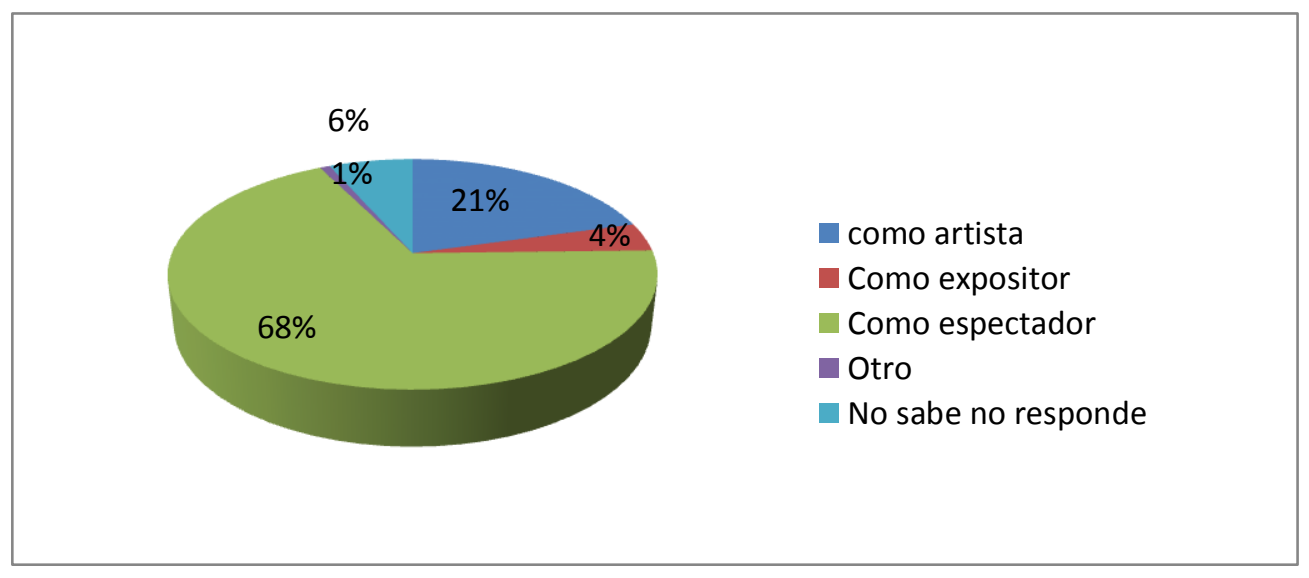

Fuente. Autoras. 
Esta pregunta nos ayuda averiguar cómo le gustaría a la mayoría de personas participar en el café cultural, lo cual arrojo que el $68 \%$ de la muestra participaría como espectador y un $21 \%$ como artista lo que nos indica que tenemos gran cantidad de clientes potenciales y una cantidad apreciativa de posibles artistas a contratar.

Figura 8.¿Cuánto estaría dispuesto a invertir por el servicio dentro de un café-bar donde se realicen actividades culturales?

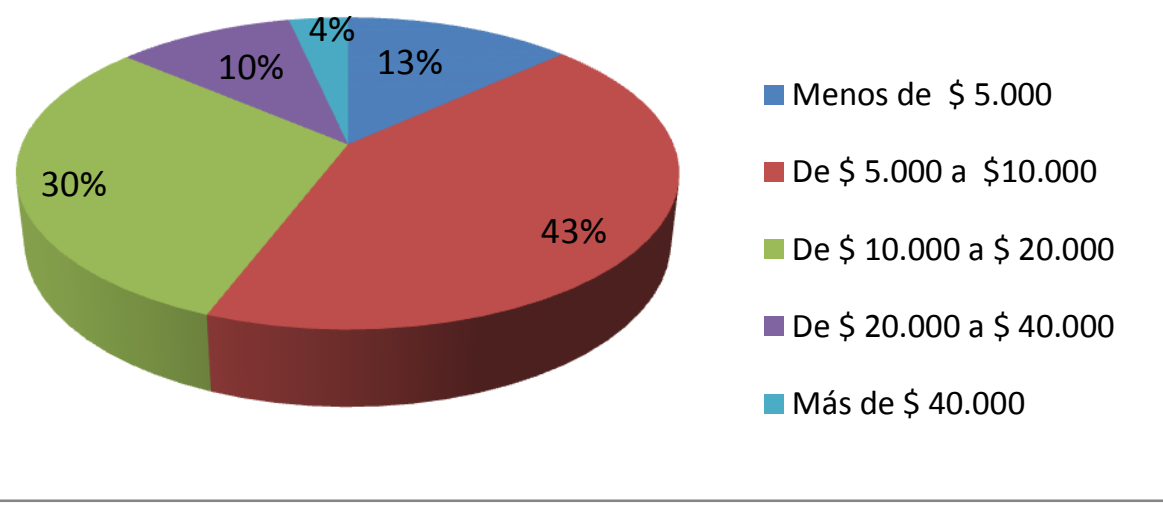

Fuente. Autoras.

El $43 \%$ de la población encuestada estaría dispuesto a invertir entre $\$ 5.000$ y $\$ 10.000$ por el servicio que se ofrecería en el centro cultural, esto nos indica un buen resultado ya que se puede determinar que las personas estarían dispuestas a pagar una suma considerable por un servicio y producto de buena calidad.

Figura9. ¿Cuándo usted sale a un café-bar que le es más conveniente?

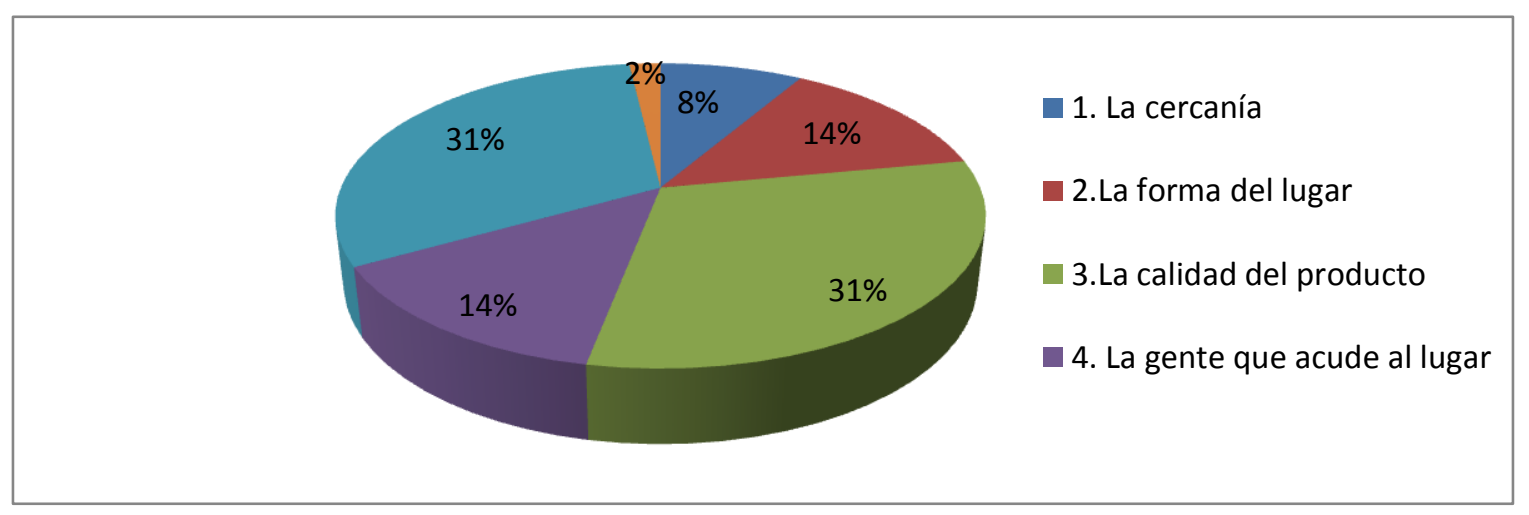

Fuente. Autoras. 
El 31\% de las personas encuestadas indican que lo más conveniente a la hora de asistir a un café-bar es la calidad del producto, resultado positivo para el análisis de mercado ya que nuestra estrategia se enfoca básicamente en este campo y las actividades que se realicen en el lugar.

Figura 10. ¿Qué es lo más importante para usted dentro de un café-bar?

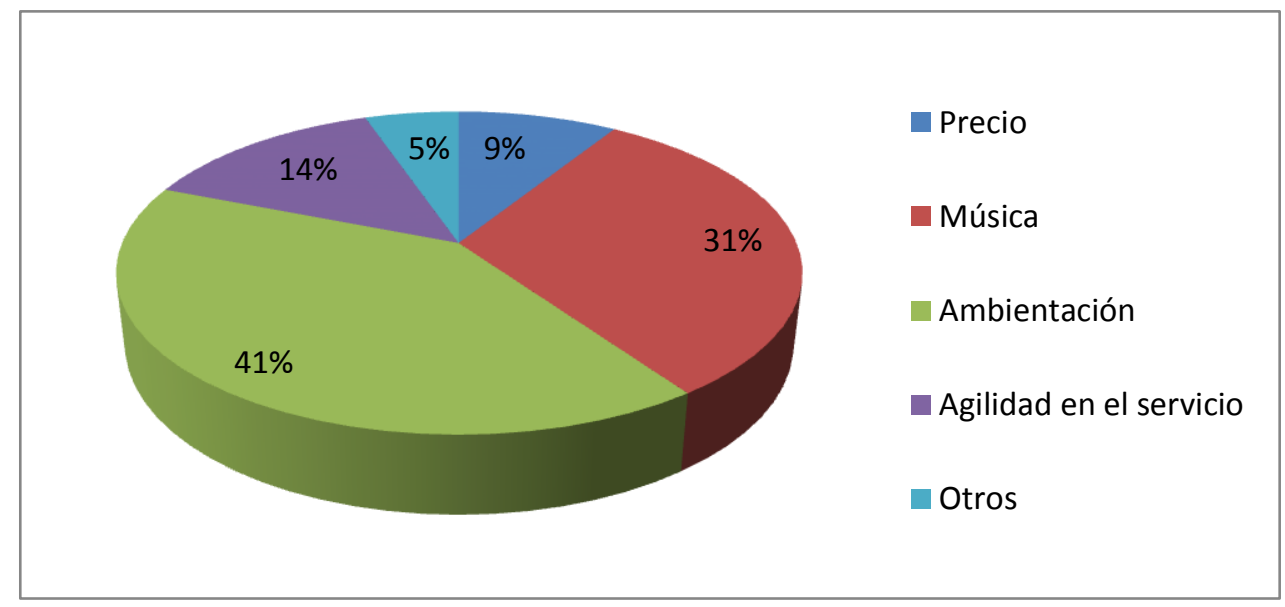

Fuente. Autoras.

Es importante conocer el tipo de servicio que los clientes esperan encontrar en un cafébar, con el fin de atender sus necesidades y expectativas. El $41 \%$ de la población encuestada considera que lo más importante en este tipo de establecimientos es la ambientación y la música con un $31 \%$, por lo tanto se puede concluir que lo más trascendental para el consumidor se encuentra en el diseño del establecimiento. 
Figura 11. ¿Qué le gustaría encontrar en un café cultural?

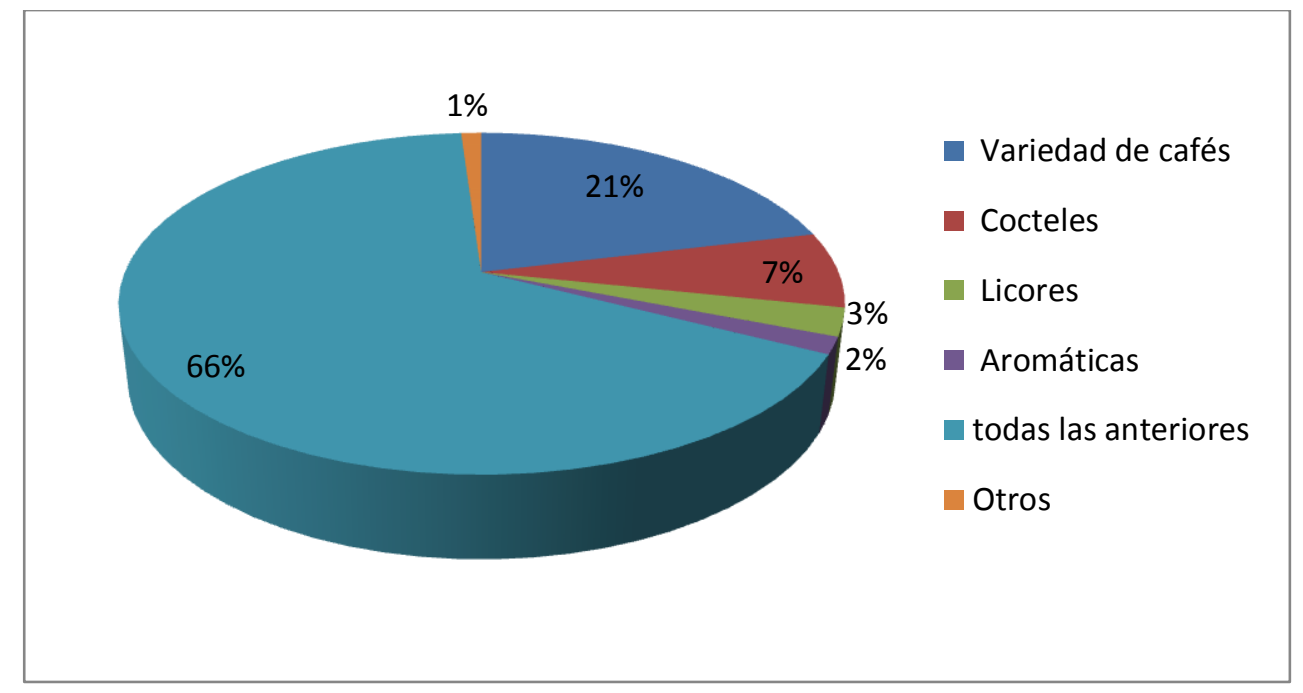

Fuente. Autoras.

Con un $66 \%$ de la población encuestada obtenemos un resultado en el que podemos deducir que una gran variedad de productos es un plus para la propuesta realizada.

Figura 12. ¿Qué actividades le gustaría encontrar en el café cultural?

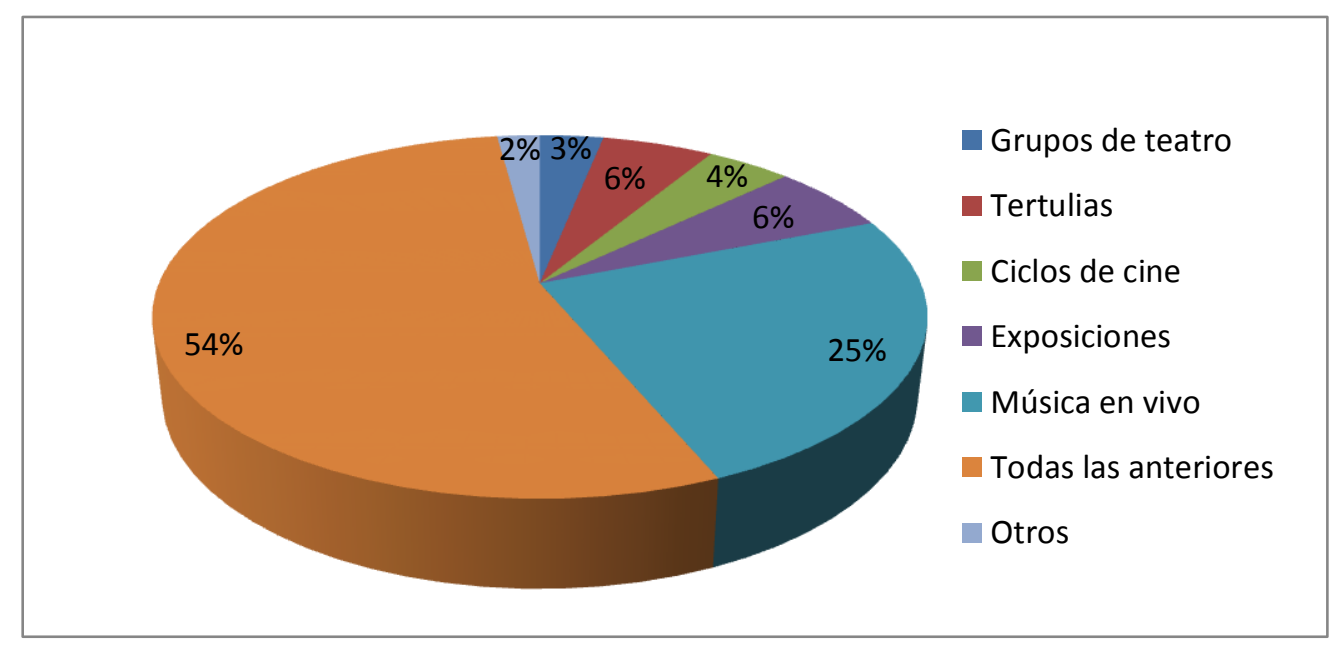

Fuente. Autoras.

El 54\% de los encuestados seleccionaron la opción de todas las anteriores; como centro de acopio cultural se presentaran todas las manifestaciones artísticas anteriormente descritas, 
teniendo en cuenta que el $25 \%$ de los encuestados selecciono la opción de música en vivo, la cual se implementara con mayor frecuencia.

Figura 13. Escoja de las siguientes actividades culturales cual es la más importante para usted.

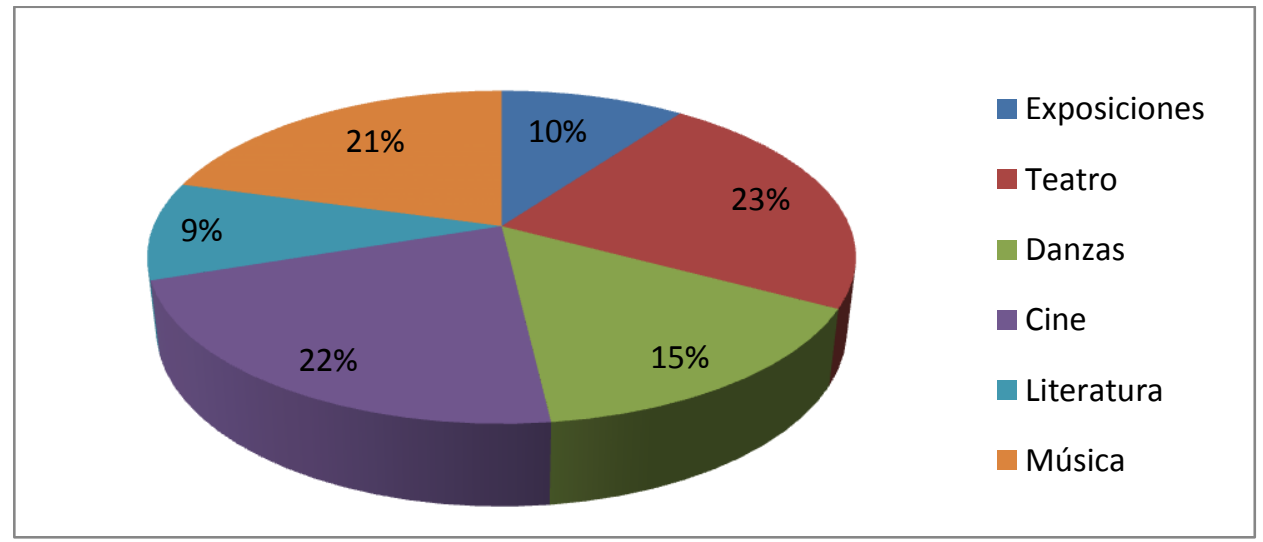

Fuente. Autoras.

De acuerdo a la población encuestada el $23 \%$ de la muestra le parece más importante el teatro como actividad cultural dentro del centro de acopio cultural, seguido del cine con un $22 \%$ y música con un $21 \%$. Esto nos indica que se debe enfatizar más en la gestión con grupos $\mathrm{y}$ artistas teatrales.

Figura 14. ¿Con que frecuencia a la semana visita usted un café-bar?

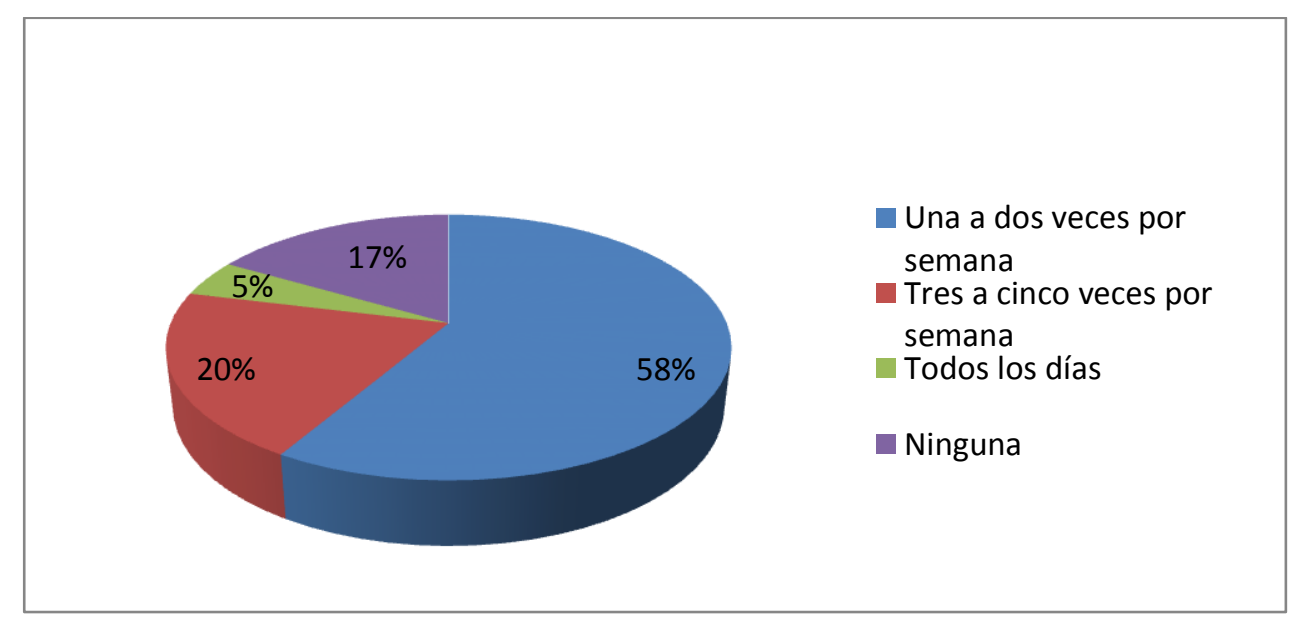

Fuente. Autoras. 
Las población de la muestra el 58\% respondió que visitan de una a dos veces por semana un café-bar, de lo que se puede concluir que una cantidad favorable puede llegar hacer cliente potencial del centro de acopio cultural.

Figura 15. ¿Para usted en qué lugar le gustaría que este ubicado el café cultural?

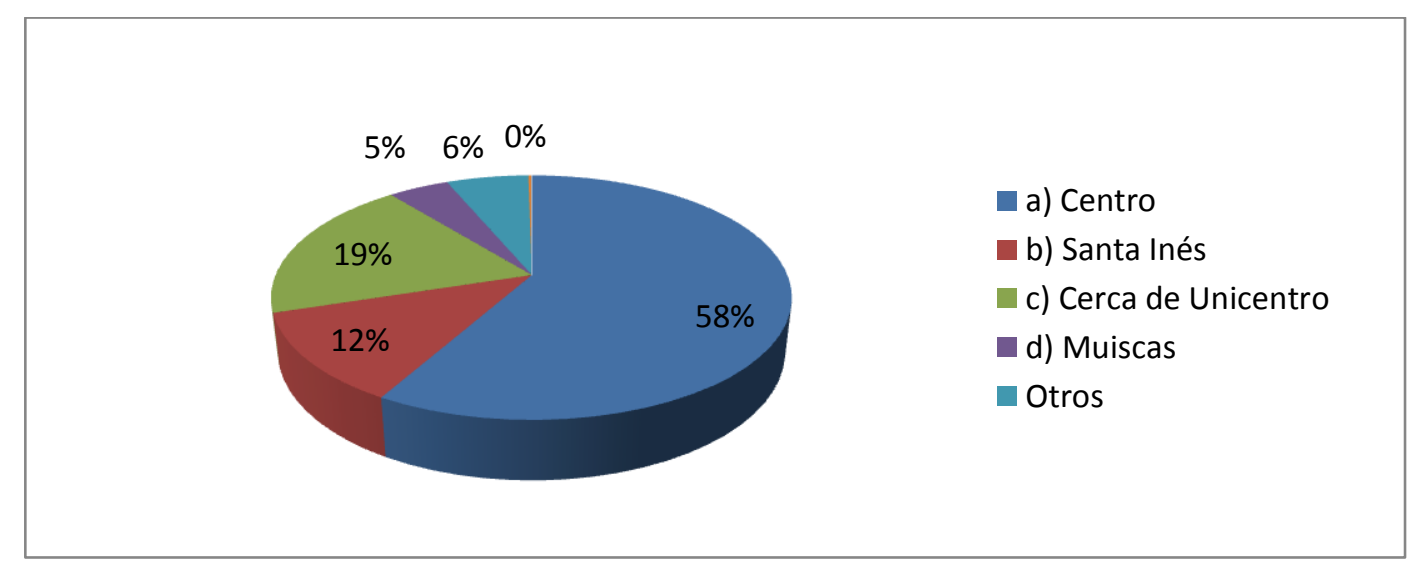

Fuente. Autoras.

El 58\% de la población encuestada le gustaría la ubicación del centro de acoplamiento cultural en el centro de la ciudad de Tunja, esto es conveniente para la idea de negocio ya que en el centro, además de población estudiantil se encuentra personas trabajadoras a las que se puede ofrecer el servicio.

\section{Análisis general de la encuesta}

En general según las respuestas de las encuestas la idea de negocio es viable, ya que el 99\% está de acuerdo con la creación de un café cultural,además de la cantidad de personas que estarían dispuestas a asistir a los eventos del centro de acoplamiento cultural como espectadores, invirtiendo entre $\$ 5000$ o $\$ 10000$ pesos por cada vez que asistan; el $68 \%$ de las personas están dispuestas asistir al café de una a dos veces por semana.

En cuanto a gustos la mayoría de las personas se fijan en la decoración del lugar al cual se van a tomar el café, la agilidad en el servicio y que se ofrezca cierta calidad en el producto. 
Si se habla de los servicios en gestión cultural, para la población es más importante encontrar ciclos de cine y le gustara que se presentara obras de teatro.

Determinación de la Demanda. Para le determinar la demanda potencial del centro de acoplamiento cultural, se toma el total de población estudiantil entre 35 y 18 años de edad, siendo 21903 este se multiplica por el $99 \%$ que es el porcentaje de las personas que les gustaría que existiera un café cultural en la ciudad de Tunja, y el resultado es 21682, con este resultado se saca el $87 \%$ de las personas que participarían en las actividades del café cultural que son 18865 , luego se aplica un $68 \%$ de personas que participan como espectadores de actividades culturales, 12828 por el $58 \%$ lo que concluye con una demanda potencial semanal de 7440 personas que irían una o dos veces por semana.

\section{Comportamiento Histórico}

\section{Segmento del Mercado}

- Población. Personas entre 18 y 35 que sean estudiantes universitarios de la ciudad de Tunja; la cual según el Danecorresponde a 21903 para el año 2013.

\section{Tabla 2.}

Proyección poblacional de Tunja.

\begin{tabular}{lllllllll}
\hline Año & $\mathbf{2 0 1 3}$ & $\mathbf{2 0 1 4}$ & $\mathbf{2 0 1 5}$ & $\mathbf{2 0 1 6}$ & $\mathbf{2 0 1 7}$ & $\mathbf{2 0 1 8}$ & $\mathbf{2 0 1 9}$ & $\mathbf{2 0 2 0}$ \\
\hline $\begin{array}{c}\text { Población } \\
\text { Total Tunja }\end{array}$ & 181,407 & 184,820 & 188,340 & 191,878 & 195,496 & 199,137 & 202,939 & 206,791 \\
\hline Fuente. DANE -Proyección Municipios $2005-2020$. & & & & & \\
Del total de la población de Tunja se toma como población universo las personas entre \\
los 18 y 35 años del municipio.
\end{tabular}




\section{Tabla 3.}

Proyección de la población de Tunja entre los 18 a 35 años.

\begin{tabular}{ccccccccc}
\hline Año & $\mathbf{2 0 1 3}$ & $\mathbf{2 0 1 4}$ & $\mathbf{2 0 1 5}$ & $\mathbf{2 0 1 6}$ & $\mathbf{2 0 1 7}$ & $\mathbf{2 0 1 8}$ & $\mathbf{2 0 1 9}$ & $\mathbf{2 0 2 0}$ \\
\hline Población entre 18 y 35 años & 55415 & 56072 & 56719 & 57343 & 57921 & 58506 & 59169 & 59981 \\
\hline
\end{tabular}

Fuente.Dane- Visor Certifica PPT_Oct11

De acuerdo con esta población se trabaja como población objetivo la población estudiantil de la ciudad de Tunja.

\section{Tabla 4.}

Proyección estudiantil de Tunja.

\begin{tabular}{lcccccccc}
\hline Año & $\mathbf{2 0 1 3}$ & $\mathbf{2 0 1 4}$ & $\mathbf{2 0 1 5}$ & $\mathbf{2 0 1 6}$ & $\mathbf{2 0 1 7}$ & $\mathbf{2 0 1 8}$ & $\mathbf{2 0 1 9}$ & $\mathbf{2 0 2 0}$ \\
\hline \multirow{2}{*}{ Población Estudiantil } & 21903 & 22163 & 22425 & 22691 & 22960 & 23233 & 23508 & 23787 \\
\hline
\end{tabular}

Fuente. Dane- Educación Tunja por edad y Niveles

Zona de Influencia. La zona de influencia en la cual se va a desarrollar el proyecto es la ciudad de Tunja, específicamente en el barrio Maldonado, ya que es un lugar cerca al centro histórico de la ciudad, que por sus antecedentes históricos se presta para retomar la historia de las diferentes colonias que habitaron a través de los tiempos,lo cual es un atractivo para la idea del centro de acoplamiento cultural en el cual las manifestaciones artísticas pueden tener ese contenido histórico cultural.

Figura 16. Mapa ubicación del zona de ubicación del negocio.

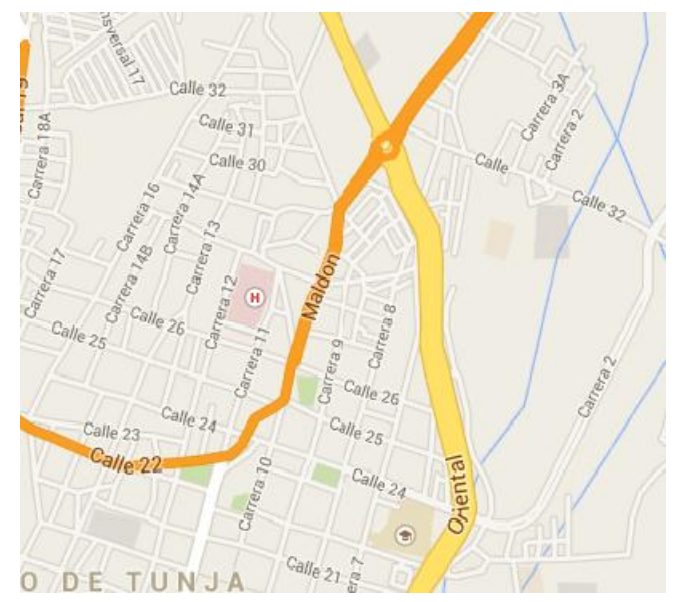

Fuente. Google maps. (en línea) URL: https://www.google.com/maps. 
Consumo Aparente. De acuerdo con los porcentajes arrojados por la encuesta realizada a las 378 personas de la muestra poblacional, se obtuvo una demanda potencial de 7440, es decir, 7440 personas irían de una a dos veces por semana al centro de acoplamiento cultural.

Consumo Percapita. Según la pregunta de cuanto invertiría en el café cultural por casa vez que asista se toman los siguientes porcentajes aplicados a la población objetivo de la siguiente manera: un porcentaje de $48 \%$ que es igual a 9418 personas que consumirían productos que sumen de 5000 a 10000 independiente de que producto consuma, un 30\% igual a 6571 personas que consumen entre 10000 y 20000, un 13\% igual 2847 personas que consume dentro de un margen de menos de 5000, el 10\% igual a 2190 personas consumirán entre 20000 y 40000 y por ultimo un $4 \%$ igual a 876 personas que consumirán producto que sumen más de 40000 pesos.

\section{Características Teóricas de la Demanda}

Función de Demanda. La función de demanda resulta de la relación inversa que existe entre precio y cantidad, es decir cuando el precio del servicio disminuye, los consumidores lo adquieren en mayor proporción, que con un precio alto, matemáticamente la función de demanda se expresa así:

$$
P=f(q 1, q 2 \ldots I)
$$

Para representarlo en el proyecto del centro de acopio cultural se toma por intervalos de la cantidad de dinero que la gente invertiría por cada vez que acude al café. Lo que nos queda una curva expresada así: 
Figura 17. Grafica de demanda del servicio.

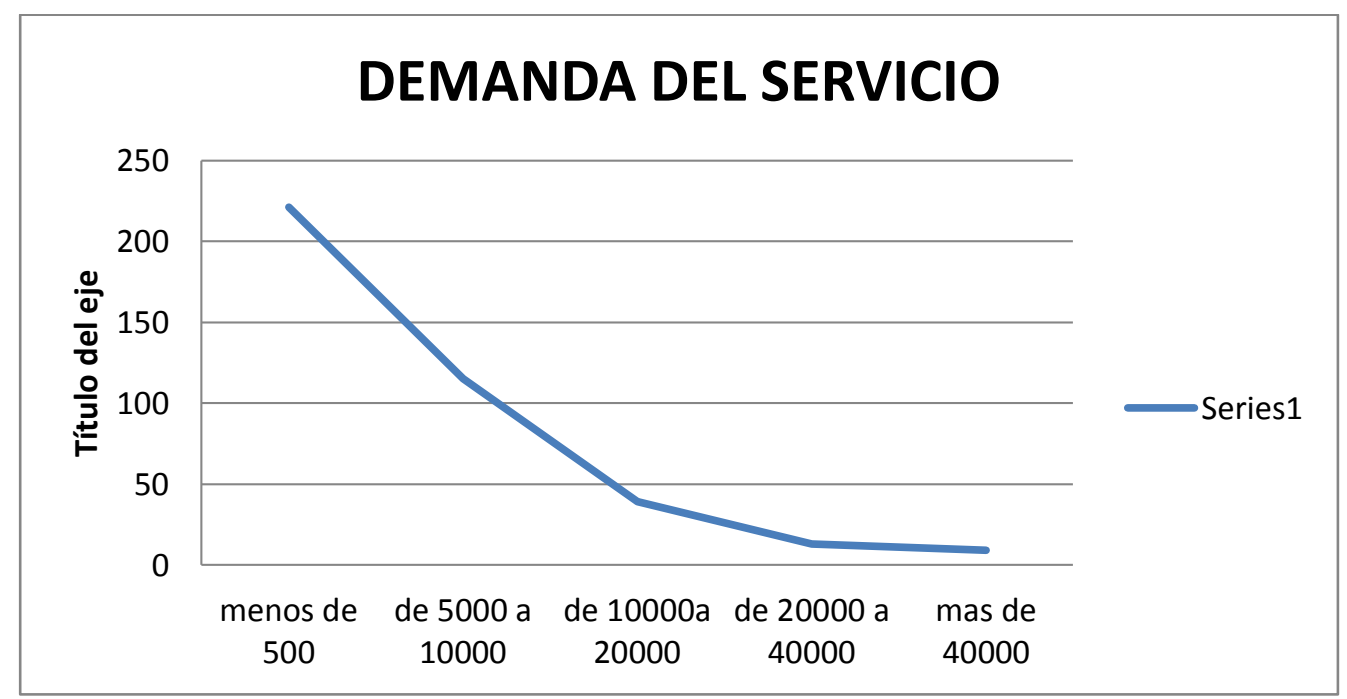

Fuente. Autoras.

Función de Ingreso. En la tabla 5 se muestra en la columna 5 el gasto promedio por persona en las diferentes manifestaciones artísticas y en el servicio de bebidas calientes de cafetería y en bebidas alcohólicas.

\section{Tabla 5.}

Ingresos y gastos de Tunja.

\begin{tabular}{|l|c|c|c|c|}
\hline \multicolumn{1}{|c|}{$\begin{array}{c}\text { Dominios de estudio y clasificación del } \\
\text { gasto }\end{array}$} & $\begin{array}{c}\text { Total de } \\
\text { hogares }\end{array}$ & $\begin{array}{c}\text { Gasto total } \\
\text { (millones \$) }\end{array}$ & $\begin{array}{c}\text { Gasto promedio } \\
\text { por hogar que } \\
\text { adquiere el bien o o } \\
\text { servicio (\$) }\end{array}$ & $\begin{array}{c}\text { Gasto promedio } \\
\text { por persona del } \\
\text { dominio de } \\
\text { estudio (\$) }\end{array}$ \\
\hline Entradas a cine & 129,110 & 4,242 & 12,740 & 3,879 \\
\hline Entradas a teatro & 12,627 & 647.582 & 19,888 & 5,471 \\
\hline $\begin{array}{l}\text { Entradas a espectáculos musicales: } \\
\text { conciertos, óperas, ballets, zarzuela, } \\
\text { etc. }\end{array}$ & 13,407 & 245.12 & 7,090 & 2,105 \\
\hline $\begin{array}{l}\text { Entradas a museos, galerías de arte y } \\
\text { exhibiciones }\end{array}$ & 10,983 & 226.60 & 8,001 & 2,574 \\
\hline $\begin{array}{l}\text { Entradas a bibliotecas, hemerotecas y } \\
\text { archivos }\end{array}$ & 1,734 & 104.97 & 23,481 & 4,992 \\
\hline $\begin{array}{l}\text { Bebidas calientes en cafeterías y } \\
\text { similares: Tinto, café con leche, } \\
\text { chocolate, té, bebida achocolatada } \\
\text { caliente, leche, agua de panela, agua } \\
\text { aromática, avena caliente y similares }\end{array}$ & 636956 & 8,102 & 4,932 & 1,206 \\
\hline $\begin{array}{l}\text { Gastos en bebidas alcohólicas } \\
\text { (cerveza, aguardiente, ron, etc) en } \\
\text { tiendas, fondas rurales y al aire libre }\end{array}$ & 273968 & 15877.33042 & 22,473 & 5,715 \\
\hline
\end{tabular}

Fuente. Daneencuesta nacional de ingresos y gastos 2006-2007. 
La función de ingreso se representa en a mayor ingresos de los consumidores mayor gasto en el café.

Figura 18. Grafica Función de ingreso.

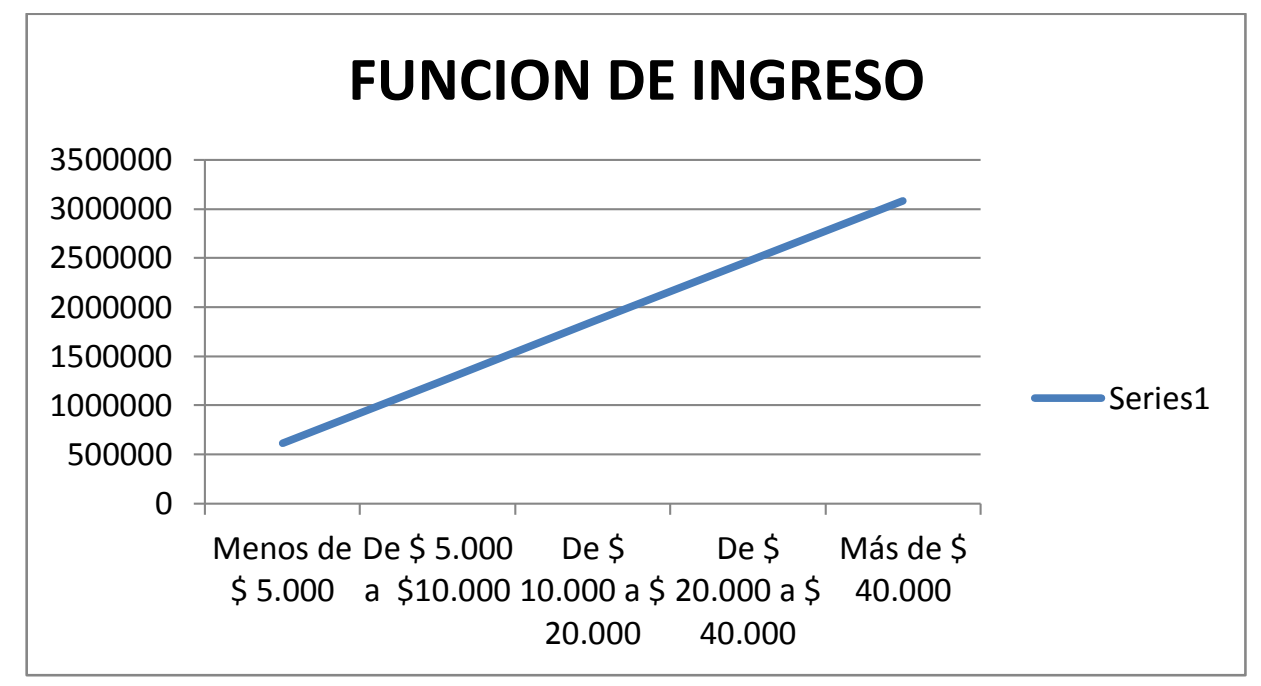

Fuente. Autoras.

Elasticidad de la Demanda. La elasticidad se define como la relación que existe entre la variación de cantidad y la variación de cantidad, para el centro de acopio cultural se toma cantidad $1=221$ cantidad $2=115$, y precio $1=10000$ y precio $2=20000$.

La fórmula matemática es:

$$
\boldsymbol{E P}=\frac{\Delta \boldsymbol{Q}}{\Delta \boldsymbol{P}}=\frac{\boldsymbol{P} * \Delta \boldsymbol{Q}}{\boldsymbol{Q} * \Delta \boldsymbol{P}}
$$

Por lo tanto la elasticidad de la demanda para un centro de acopio cultural seria así:

$$
\begin{gathered}
E P=\frac{20000 *(221-115)}{221 *(20000-10000)} \\
E P=-1.84
\end{gathered}
$$

Si el resultado es mayor a 1 significa que la demanda es elástica, es decir, si los precios bajan los gastos totales del servicio aumentarían. 
Estimación de la Demanda Futura. Luego de tener la demanda actual se realiza una proyección a 5 años con el mismo porcentaje de los datos poblacionales elaborados por el Dane, para que resulte la demanda futura del año 2013 a 2020.

Tabla 7.

Demanda futura.

\begin{tabular}{|l|r|r|r|r|r|r|r|r|}
\hline & $\mathbf{2 0 1 3}$ & $\mathbf{2 0 1 4}$ & $\mathbf{2 0 1 5}$ & $\mathbf{2 0 1 6}$ & $\mathbf{2 0 1 7}$ & $\mathbf{2 0 1 8}$ & $\mathbf{2 0 1 9}$ & $\mathbf{2 0 2 0}$ \\
\hline $\begin{array}{l}\text { Población Total } \\
\text { Tunja }\end{array}$ & 181,407 & 184,820 & 188,340 & 191,878 & 195,496 & 199,137 & 202,939 & 206,791 \\
\hline $\begin{array}{l}\text { Población } \\
\text { Estudiantil }\end{array}$ & 21903 & 22163 & 22425 & 22691 & 22960 & 23233 & 23508 & 23787 \\
\hline $\begin{array}{l}\text { Demanda } \\
\text { Actual }\end{array}$ & 17904 & 18116 & 18331 & 18548 & 18768 & 18991 & 19216 & 19444 \\
\hline
\end{tabular}

Fuente.Las Autoras.

\section{Análisis de la Oferta}

Objetivo de la Oferta. Identificar el comportamiento del mercado, variables como competidores, consumidores, proveedores, disponibilidad de insumos, desarrollos tecnológicos, para determinar precios del bien y servicio.

Metodología de la Oferta. Para el análisis de la oferta es necesario determinar diferentes variables, tales como población estudiantil universitaria entre los 18 a 35 años, muestra que es de 378 personas, las cuales fueron encuestadas para observar y analizar información como precios, tenencias y gustos.

\section{Variables}

- Costos y Disponibilidad de los Insumos. Los insumos que se utilizan para la realización del bien como los cafés, son cremas, azúcar, panela, frutas, salsa de chocolate, Arequipe, leche condensada y diferentes licores, los cuales se encuentran en tiendas especializadas en pastelerías, almacenes de cadena y licoreras; estos se utilizan en pequeñas 
medidas por lo que no es conveniente mantenerlos almacenados por tanto tiempo, algunos productos son perecederos.

- Restricciones determinadas por el Gobierno. Las restricciones manejadas por el gobierno son el certificado de uso de suelos que tiene como objetivo que la autoridad competente certifique que la actividad de comercio realizada sea legal y cumpla con los requerimientos adquiridos en el plan de ordenamiento territorial. Se debe diligenciar el certificado de Sayco\&Acinpro,el cualobliga a los establecimientos de comercio que trabajen con obras protegidas por derechos de autos o difusión de música pagar por estos derechos; por ultimo como establecimiento que trabaja con alimentos y bebidas es necesario adquirir el certificado sanitario el cual comprende seguridad en las instalaciones y el nivel de sanidad del establecimiento. Además se debe cumplir con los requerimientos de seguridad que expiden los bomberos, en cuanto a rutas de evacuación y las salidas de emergencia.

Para la venta de licores como cerveza tenemos como proveedor directamente BavariaS.A. quienes ofrecen cervezadediferentes marcas y tipos tales como la Club Colombia dorada, roja y negra.

- Desarrollos Tecnológicos. Los desarrollos tecnológicos que se han presentado que pueden servir para la idea del centro cultural, están las luces Ledpara escenarios de teatro, los proyectores tipo D para las películas en proyecciones digitales.

\section{Proveedores del Bien o Servicio, Análisis de Competencia}

Proveedores del bien o servicio. El proveedor más importante para el centro cultural es Café Especial Origen, el cual es un producto artesanal boyacense, que ofrece café excelso molido y en grano la forma de distribución es de la tostadora al cliente, elegido por que 
garantiza la calidad en el aroma y sabor del café y está aprobado por la federación nacional de cafeteros.

El segundo proveedor para la realización del bien y servicio son Parmalat Colombia, es una empresa industrial de productos lácteos en Colombia, el método de distribución que frece es de la productora al centro de encuentro cultural, siendo Tunja punto de distribución, garantizan la vida útil de la leche entre seis y nueve meses de la leche en bolsa, nueve a doce meses la leche en polvo y la crema de leche, el arequipe y la leche condensada entre seis y nueve meses. Se decidió por este proveedor ya que ofrece leche en polvo y leche pasteurizada, de las cuales son necesarias para la elaboración de algunas bebidas.

Para la elaboración de las bebidas a base de se te elige como proveedor a la marca Te Hindú, el cual tiene en el mercado té verde, te negro y te rojo para infusión, además de té verde, te rojo y te negro para tomar frio, la manera de distribución es de la planta al cliente, con envidos a nivel nacional.

Análisis de competencia. Según las encuestas realizadas a 378 estudiantes universitarios en la ciudad de Tunja, el competidor directo para el centro cultural es Clandestino Café Libro, en el cual sus precios están un margen de 1000 a 4500, siendo 1000 el tinto y las infusiones y 4500 las malteadas y jugos naturales, los licores que allí se encuentran esta cerveza nacional con un precio de 2500 y el vino con precio de 4500 por copa y 35000 por botella.

Régimen del Mercado. En la ciudad de Tunja se encuentran 61 establecimientos registrados en industria y comercio con la actividad de servicio de café-Bar, pero entre estos no existe un control dominante por ninguno presentándose así una competencia monopolística, por lo tanto el Centro de acoplamiento cultural sería el único ya que presenta la mezcla de servicios culturales con los servicios de un café. 
Régimen y Características del Mercado de los Insumos. El mercado de los insumos utilizados para el centro de acoplamiento cultural en la ciudad de Tunja es de oligopolio, ya que se encuentran gran variedad de marcas de café y té, de las cuales ninguna se produce como tal en la ciudad pero si se distribuyen de otros municipios a nivel departamental y nacional estos oscilan entre un margen de precios; en cuanto a los lácteos en la ciudad se encuentra tanto marcas de otros municipios como productoras de la ciudad, igualmente los precios de estos bienes se manejan entre el mismo rango.

Comportamiento Histórico del Sector. Tunja es una ciudad que se caracteriza por su riqueza cultural, donde siempre se encuentra una fascinación por el arte, el teatro, la música, exposiciones fotográficas, de pintura y escultura; además por arquitectura colonial e indígena donde se evidencia la evolución de la población tunjana desde sus antepasados. El servicio de café en Tunja no solo es visto como un negocio, también se ve como un costumbres de la población, visitar estos sitios para tomar café con amigos y compañeros, costumbre que se pasa por generaciones, en la actualidad en la ciudad de Tunja existen 61 establecimientos de comercio que brindan el servicio de café, donde se incluyen bebidas calientes y bebidas frías.

Análisis de Sector. El servicio de café se encuentra en el tercer sector económico como prestación de servicios. Es decir no es un sector productivo pero determina ingresos a una población determinada.

Sector a nivel internacional. A nivel internacional las tiendas de café está creciendo de tal manera que tomarse un café es toda una experiencia, donde se habla de microlotes, molienda, variedades de cafés especiales y formas de preparación de este tanto como el Chemex, el Aeropress, el Ibrik, el Sifón entre muchas otra preparaciones, formando una subcultura, presente en los Estados Unidos, Europa, Asia y los Países Nórdicos. 
Sector a nivel nacional. A nivel nacional el sector cafetero está tomando nuevas tendencias, Colombia al ser el segundo productor de café en el mundo, se considera uno de los países que menos lo consume; gracias a la federación nacional de cafeteros y su campaña toma café, se incentiva a la población a conocer los diferentes aspectos culturales y sociales del café, además de la cantidad de tiendas especializadas en café que se han creado a nivel nacional y están creciendo a nivel internacional.

En el ámbito nacional los precios de los cafés oscilan entre 1800 de los expresos y los cafés especiales tienen un precio por medio en un margen de 3500 y 8000 . Para las tiendas de café especializadas.

\section{Características de la oferta}

Función de la Oferta. Lafunción de oferta fue tomada por consumo de los clientes. Es decir, entre mayor consumo mayor cantidad de bebidas ofrecidas. Matemáticamente seria de la siguiente manera:

$$
f(x)=5000 x
$$

Donde x es la cantidad de bebidas ofrecidas mientras que 5000 es la mínima cantidad que los clientes estarían dispuestos a pagar, por cada una de las veces que entre al lugar, sin importar la bebida que consuman.Según esto nos da una curva de oferta así: 
Figura 19. Grafica Oferta del servicio.

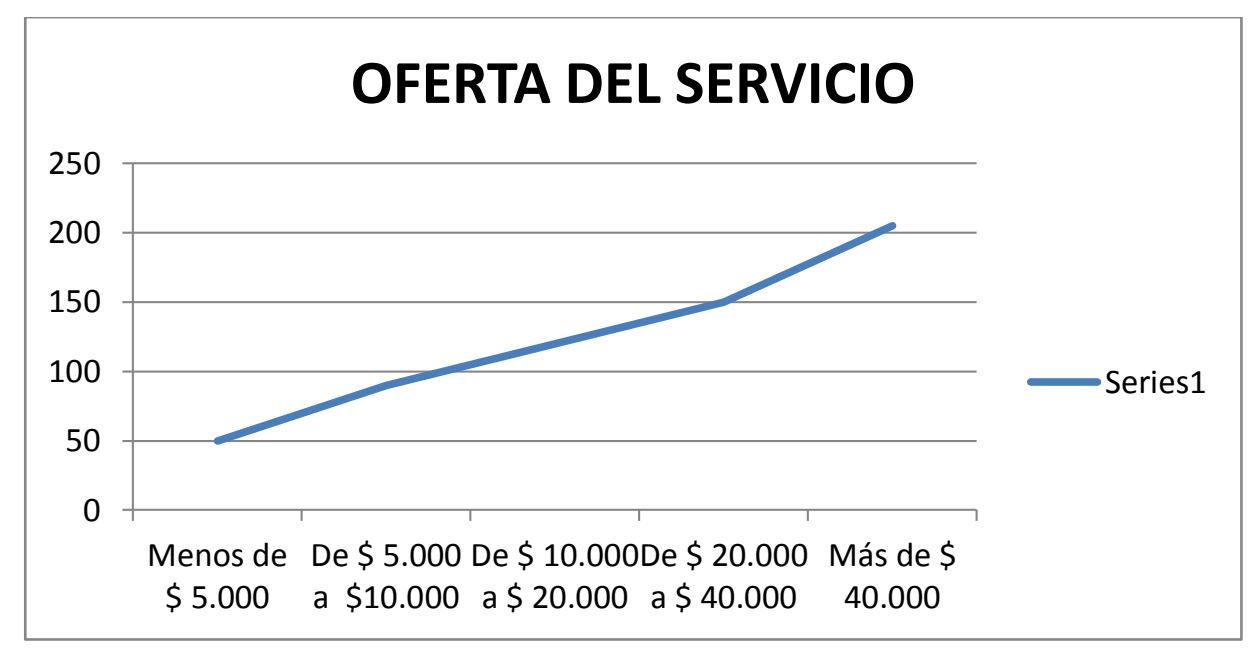

Fuente.Las Autoras.

Proyección de la Oferta. La proyección de oferta se toma la cantidad de bebidas que tiene la máquina de producción por hora que es de 30 bebidas por hora, esto se multiplica por 48 horas a la semana, luego por 4 semanas, por ultimo por 12 meses, lo que resulta 17280 bebidas al año. Se utilizó el porcentaje según el Danepara la proyección poblacional.

\section{Tabla 8.}

Proyección de la oferta.

\begin{tabular}{lrrrrrrrr}
\hline & $\mathbf{2 0 1 3}$ & $\mathbf{2 0 1 4}$ & $\mathbf{2 0 1 5}$ & $\mathbf{2 0 1 6}$ & $\mathbf{2 0 1 7}$ & $\mathbf{2 0 1 8}$ & $\mathbf{2 0 1 9}$ & $\mathbf{2 0 2 0}$ \\
\hline $\begin{array}{l}\text { Población Total } \\
\text { Tunja }\end{array}$ & 181,407 & 184,820 & 188,340 & 191,878 & 195,496 & 199,137 & 202,939 & 206,791 \\
\hline $\begin{array}{l}\text { Población } \\
\text { estudiantil }\end{array}$ & 21903 & 22163 & 22425 & 22691 & 22960 & 23233 & 23508 & 23787 \\
\hline Oferta actual & 17280 & 17485 & 17692 & 17902 & 18114 & 18329 & 18546 & 18766 \\
\hline
\end{tabular}

Fuente. Las Autoras.

Demanda Vs Oferta.Para determinar la demanda insatisfecha la cual se produce cuando las demandas detectadas no son lo suficiente atendidas en el mercado, para esto tomamos el déficit de la siguiente manera:

$$
\text { deficit }=\text { demanda }- \text { oferta }
$$


Para esto se tomó la demanda potencial como los 17904 encuestados que respondieron que si ala a pregunta de si le gustaría, proyectada a un año para la oferta potencial 17280 que es la capacidad de producción de bebidas de la máquina de café, la demanda insatisfecha resulta de la diferencia entre la oferta potencial y la demanda potencial.

\section{Tabla 9.}

Demanda Vs Oferta.

\begin{tabular}{lrrrrrrrr}
\hline & $\mathbf{2 0 1 3}$ & $\mathbf{2 0 1 4}$ & $\mathbf{2 0 1 5}$ & $\mathbf{2 0 1 6}$ & $\mathbf{2 0 1 7}$ & $\mathbf{2 0 1 8}$ & $\mathbf{2 0 1 9}$ & $\mathbf{2 0 2 0}$ \\
\hline Demanda actual & 17904 & 18116 & 18331 & 18548 & 18768 & 18991 & 19216 & 19444 \\
\hline Oferta actual & 17280 & 17485 & 17692 & 17902 & 18114 & 18329 & 18546 & 18766 \\
\hline Demanda insatisfecha & 624 & 631 & 639 & 646 & 654 & 662 & 670 & 678 \\
\hline
\end{tabular}

Fuente. Las autoras.

Proyectados según el $1.18 \%$ de acuerdo la proyección poblacional aplicada por el Dane.

Función de Precios. En el café cultural se encuentran diferentes precios, pues la bebida base para los cafés es el expreso y de acuerdo a los gustos de cada uno de los clientes, va cambiando de acuerdo al café que prefieren los clientes.

Para la determinación del precio primero es necesario sacar los costos de cada uno de los productos que se van a ofrecer.

\section{Tabla 10.}

Función de precios.

\begin{tabular}{|c|c|c|c|c|c|c|c|c|c|c|c|c|}
\hline & $\begin{array}{l}\text { Café } \\
\text { expreso }\end{array}$ & $\begin{array}{l}\text { Café } \\
\text { americano }\end{array}$ & $\begin{array}{l}\text { Capuchin } \\
0\end{array}$ & $\begin{array}{l}\text { Café } \\
\text { Latte }\end{array}$ & $\begin{array}{l}\text { Capuchino } \\
\text { con Licor }\end{array}$ & Mocachino & $\begin{array}{l}\text { Café } \\
\text { Gelato }\end{array}$ & Irish Coffe & $\begin{array}{l}\text { Expreso } \\
\text { Correto }\end{array}$ & $\begin{array}{l}\text { Capuchin } \\
\text { o helado }\end{array}$ & Cerveza & Vino \\
\hline $\begin{array}{l}\text { total costo de } \\
\text { produccion }\end{array}$ & 475 & 625 & 697 & 687 & 1558 & 704 & 1174 & 1764 & 1375 & 850 & 1306 & 3374 \\
\hline $\begin{array}{l}\text { margen de } \\
\text { rentailidad 25\% }\end{array}$ & 119 & 156 & 174 & 172 & 389 & 176 & 293 & 441 & 39 & 213 & 327 & 844 \\
\hline $\begin{array}{l}\text { total costo + } \\
\text { rentabiblidad }\end{array}$ & 594 & 782 & 871 & 859 & 1947 & 880 & 1467 & 2205 & 1414 & 1063 & 1633 & 4218 \\
\hline $\begin{array}{l}\text { precio } \\
\text { competidor }\end{array}$ & 1500 & 1200 & 2300 & 2500 & 2500 & 2500 & 4500 & 5000 & 3000 & 4000 & 2500 & 4000 \\
\hline total precio & 1200 & 1000 & 1800 & 2500 & 2500 & 2500 & 4000 & 5000 & 3000 & 4000 & 2500 & 4500 \\
\hline
\end{tabular}

Fuente. Las autoras. 


\section{Estudio Técnico}

\section{Aspectos técnicos}

Marco teórico y conceptual. El estudio técnico tiene por objeto proveer información para cuantificar el monto de las inversiones y de los costos de operación pertinentes a esta área. Técnicamente existirían diversos procesos productivos opcionales, cuya jerarquización puede diferir de la que pudiera realizarse en función de su grado de perfección financiera.

Este estudio deberá definir la función de producción que optimice el empleo y los recursos disponibles del bien o servicio del proyecto.

Metodología utilizada para la formulación de los aspectos técnicos. Para la formulación de los aspectos técnicos del proyecto se realizara una investigación cuantitativa y cualitativa de cada uno de las características que intervienen en la composición de un café cultural tales como la maquinaria, costos de producción, la localización y los diferentes entornos que interfieren en los procesos y estándares de calidad que requiera el proceso.

Tamaño del proyecto: volúmenes de producción y comercialización del bien o servicio proyectados.El servicio de un café cultural tiene como objetivo brindar un espacio de esparcimiento que permita la interacción del ocio con el arte, dando así como resultado la prestación de un servicio que satisfaga la demanda de los clientes potenciales, en este caso tomaríamos como tamaño del proyecto la cantidad de bebidas que se producirían y venderían en el día dando así como resultado doscientas ochenta aproximadamente, esto teniendo en cuenta la cantidad de personas que asistan al lugar en días normales sin 
embargo este número podría aumentar gracias a las actividades que se desarrollarían dentro del lugar.

\section{Análisis de los factores condicionantes del tamaño del proyecto}

Tamaño y mercado. De acuerdo a los resultados arrojados en el estudio de mercados, se plantea la creación de un Centro de acoplamiento cultural en el sector del barrio Maldonado enfocado a un Segmento de mercado comprendido en un rango de edad que va desde los 18 años hasta los 35 años, que sean residentes o transeúntes del sector en mención teniendo en cuenta un total de 329 personas.

Tamaño, costos y aspectos técnicos. La población a la cual irá a impactar el proyecto según el estudio de mercados, son personas de cualquier género, creencia, raza, entre los dieciocho y treinta y cinco años, las cuales según las encuestas están dispuestas a pagar por el servicio entre $\$ 5.000$ y $\$ 10.000$.

Tabla 11.

Disponibilidad de insumos públicos.

\section{Disponibilidad de insumos}

\begin{tabular}{llll}
\hline Insumo & Precio & Cantidad ofrecida & Vida útil aprox \\
\hline Café especial origen & 60000 & 2500 gramos & 2 meses \\
\hline Leche entera Parmalat & 14000 & 6 bolsas de $1100 \mathrm{ml}$ & 6 meses \\
\hline Crema de leche & 7100 & 1100 mililitros & 2 meses \\
\hline Leche condensada & 8200 & 1100 mililitros & 2 meses \\
\hline arequipe & 9500 & 1000 gramos & 2 meses \\
\hline Leche en polvo Parmalat & 14000 & 1000 gramos & 8 meses \\
\hline Crema chantilly & 8000 & 1000 gramos & 6 meses \\
\hline Te hindú & 12300 & Caja por 200 unidades & 2 meses \\
\hline & & & \\
\hline
\end{tabular}




\begin{tabular}{llll}
\hline Azúcar & 3500 & 200 unidades x5gramos & 2 meses \\
\hline Vino & 25000 & Botella 750cc & N/A \\
\hline Esencias de sabores & 6500 & Botella $500 \mathrm{cc}$ & 6 meses \\
\hline Cocoa (chocolate enpolvo) & 17480 & 1000 gramos & 6 meses \\
\hline Galletas mini & 6000 & 12 paquetes & 4 meses \\
\hline Helado & 15000 & 5 litros & 2 meses \\
\hline Cerveza & 33000 & Canasta de 30 bot.320 cc & N/A \\
\hline Frutas & 4000 & 500 gramos & 5 días
\end{tabular}

Fuente. Las autoras.

Tabla 12.

Disponibilidad de servicios públicos.

\begin{tabular}{lll}
\hline \multicolumn{2}{c}{ Servicios públicos } \\
\hline Servicio & Estrato & Costo \\
\hline Energía & Comercial & 220000 \\
\hline Agua & Comercial & 180000 \\
\hline Gas natural & Comercial & 40000 \\
\hline Wifi, teléfono fijo & N/A & 120000 \\
\hline Televisión satelital & N/A & 60000 \\
\hline
\end{tabular}

Fuente. Las autoras

Tamaño y localización. La funcionalidad del proyecto hace que tenga una única localización, la cual será en el barrio Maldonado ya que este se encuentra en un punto estratégico de la ciudad donde el comercio va en constante crecimiento y existen diferentes servicios que le permiten al consumidor suplir distintas necesidades. 
Tamaño y Financiamiento. El proyecto será financiado por los socios de la junta administrativa, donde se comparte el $50 \%$ de responsabilidad de los costos; sin embargo será estudiado por el fondo emprender, con el fin de disminuir el porcentaje de inversión, por parte de los socios.

\section{Localización; Macro localización y Micro localización, Matriz de Planta Física.}

Localización. El centro de acoplamiento cultural será ubicado en la ciudad de Tunja en el barrio Maldonado; se toma este punto por cuestión de costos de los servicios públicos, además del certificado de estudio de suelos el cual no permite la apertura de un establecimiento de comercio donde se ofrezcan bebidas alcohólicas dentro del centro histórico de la ciudad.

Figura 20. Proceso de localización.

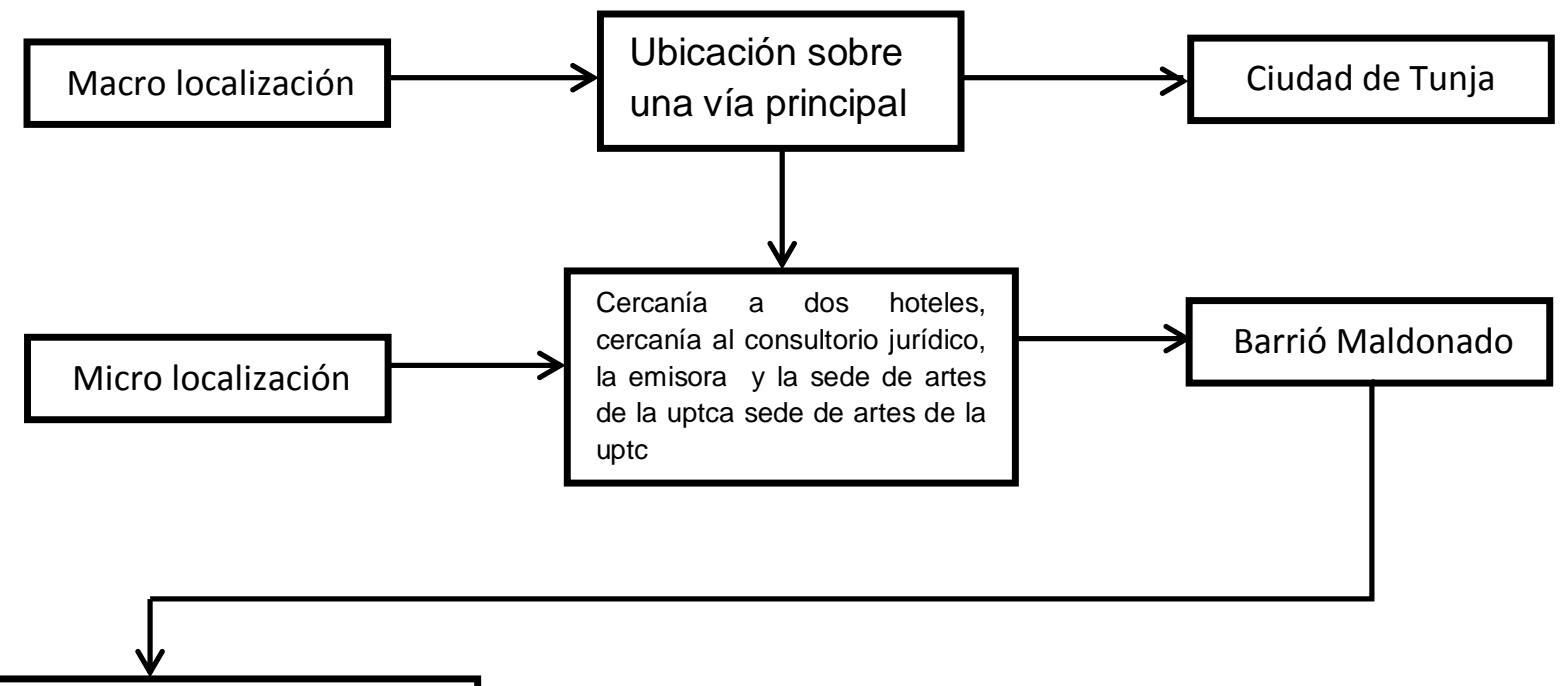

Av. Maldonado $N^{\circ} 27-63$

Fuente. Autoras. 


\section{Macro Localización}

El centro de acoplamiento cultural se desarrollara en el barrio Maldonado al occidente de la ciudad de Tunja; el sector cuenta con el 100\% de los servicios públicos, como gas natural, alcantarillado, energía, teléfono, internet y televisión.

La principal vía sobre el centro de encuentro cultural es la avenida Maldonado, esta es la más utilizada para llegar al centro histórico de la ciudad desde el norte.

La variables por la cuales fue escogido el sector fue por la cercanía a dos hoteles, queda sobre una de las vías más importantes de la ciudad, cumple con los requisitos para el certificado de estudio de suelos, la cercanía a dos hoteles conocidos de la ciudad los cuales son hotel la antigua y hotel las nieves, además del rápido acceso de los proveedores de los diferentes insumos por estar sobre la avenida Maldonado.

Figura 20. Mapa de macrolocalizaciòn.

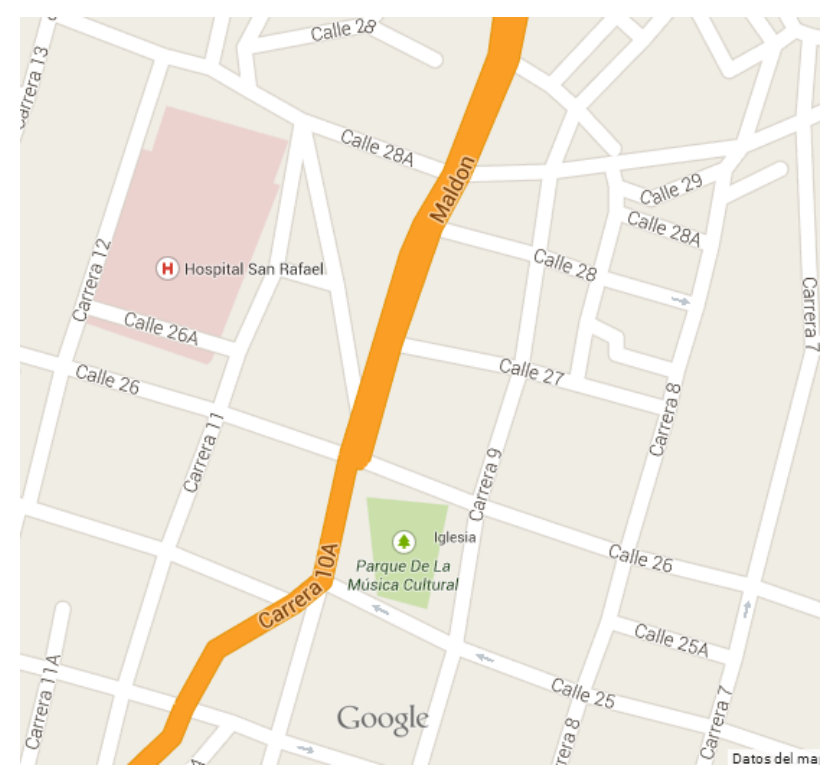

Fuente. Google maps. https://www.google.com/maps 


\section{Micro localización}

El centro de acoplamiento cultural estará ubicado en el barrio Maldonado, debido a que no hay lugares por ese sector que presten el servicio de cafetería, que sean acogedores y agradables que incentiven el dialogo y el intercambio de conocimientos por medio de las manifestaciones artísticas.

La dirección de la casa Avenida Maldonado \# 27-63 el sector es estrato socio económico 3-4 pero al ser un establecimiento de comercio la casa pasa hacer estratocomercial; es una área de 60 metros cuadrados la casa es una casa lote que se remodelara de acuerdo a los requerimientos necesarios para prestar el servicio, se llega a un acuerdo con el dueño del predio en el cual el arrendador paga el 80\% de los arreglos y los arrendatarios cumplen con el $20 \%$ lo que equivale a pintura y decoración de acuerdo al estilo y la tendencia que se va a manejar.

Los factores para tomar esta opción fueron porque es un sector muy transitado debido a que es una avenida principal, la cercanía al centro histórico de la ciudad, tiene cercanía con la sede de artes, el consultorio jurídico y la emisora de la universidad pedagógica y tecnológica de Colombia UPTC, además de la ausencia de este tipo de establecimientos en el sector. 


\section{Figura 21. Fotografía sector Maldonado.}

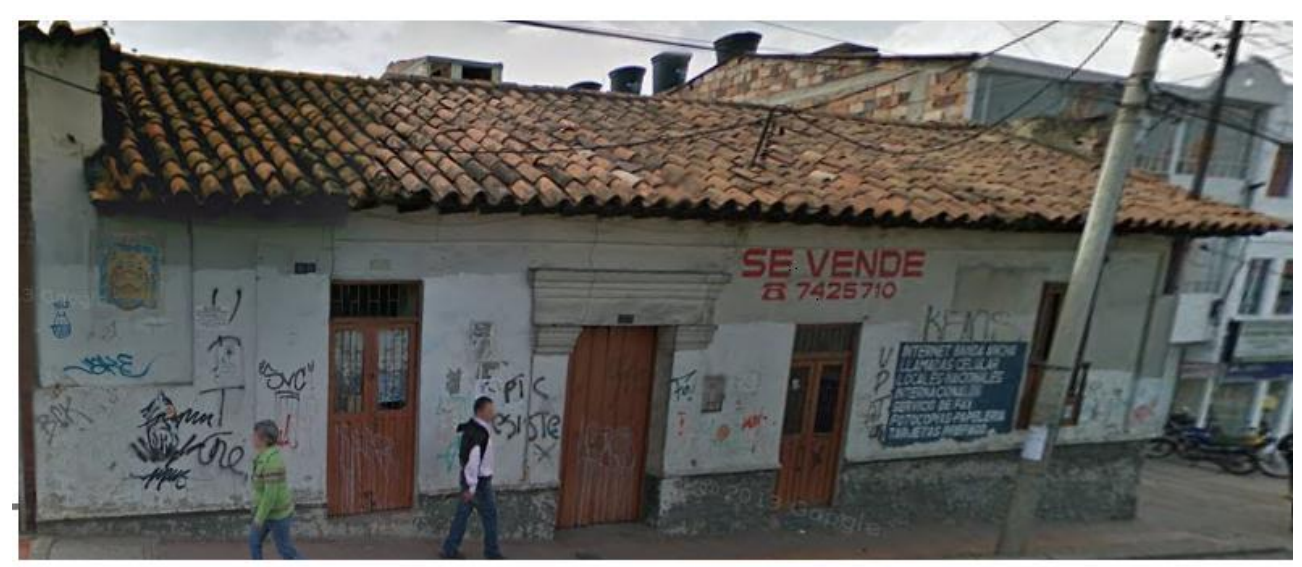

Fuente. Las autoras

\section{Ingeniería del Proyecto}

El objetivo de la ingeniería del proyecto es la programación de las diferentes tareas y procesos que se desarrollan para la prestación del servicio, adicionalmente conocer los recursos, proveedores maquinaria e infraestructura para las satisfacción del cliente.

Descripción técnica del producto. La prestación del servicio de café se ubica en el nivel tres de la escala de necesidades según Maslow“social, amistad y asociación”. La actividad se define como el servicio de venta de bebidas de café, té, infusión de frutas, licores y acompañantes.

Identificación y Selección de Procesos. Los procesos más significativos en el centro cultural es la elaboración de lasbebidas y servicio al cliente. 
Figura 22. Flujograma de elaboración de bebidas.

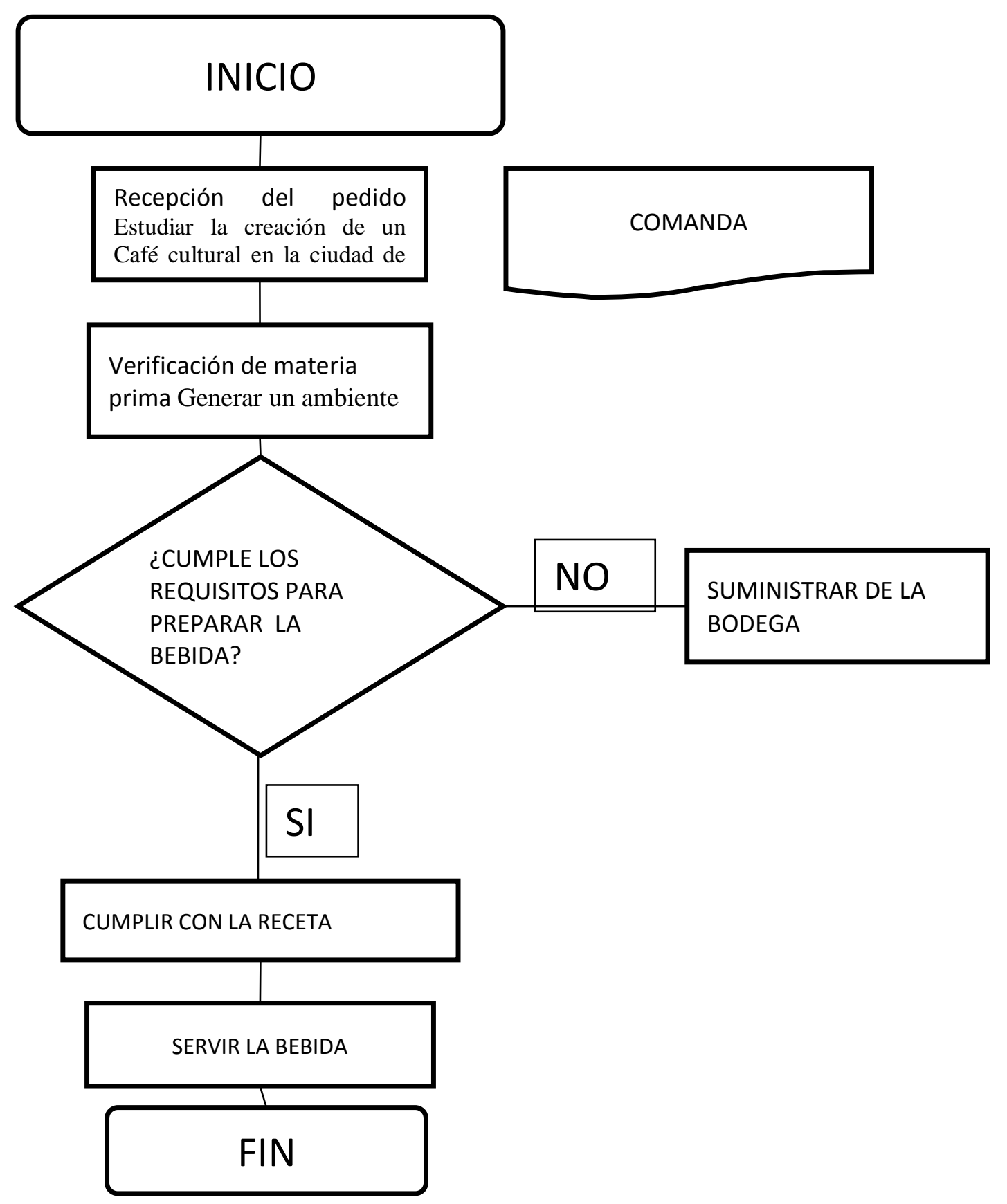


Figura 23. Flujograma de Servicio al Cliente.

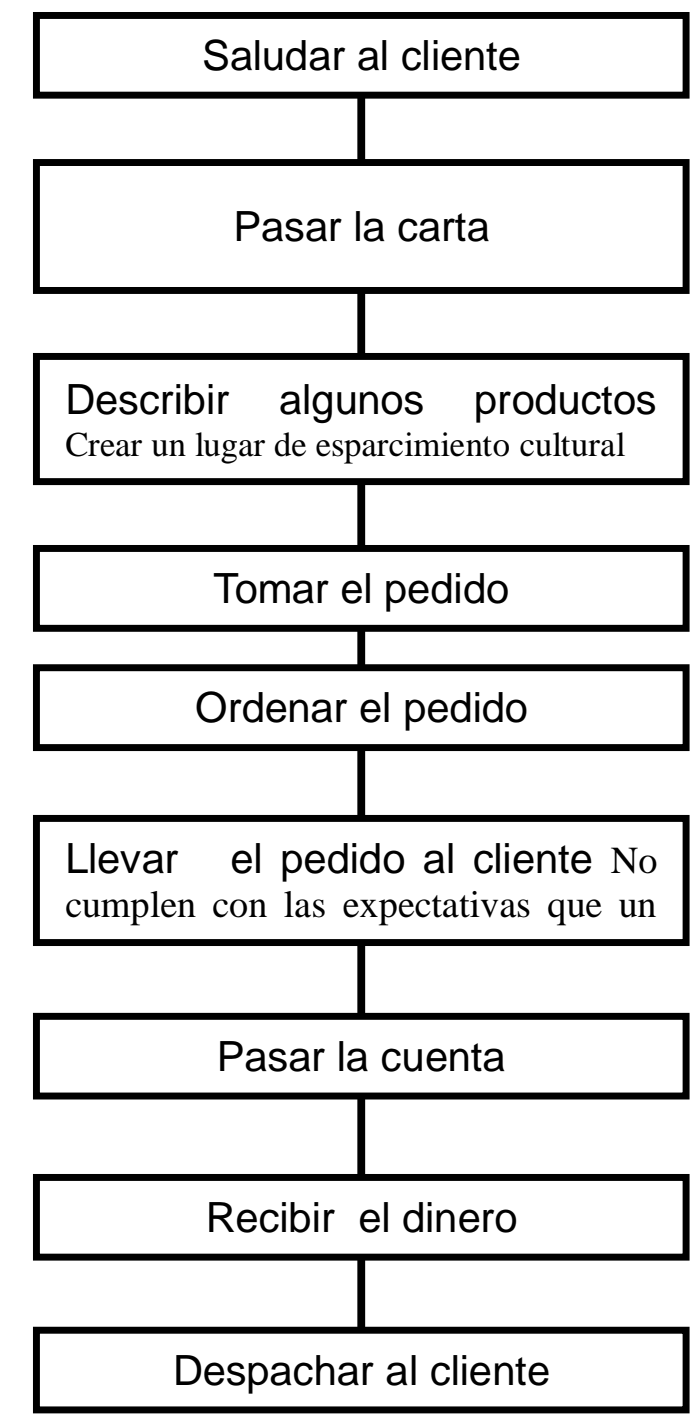


Listado de Equipos. Los equipos utilizados en la prestación del servicio son:

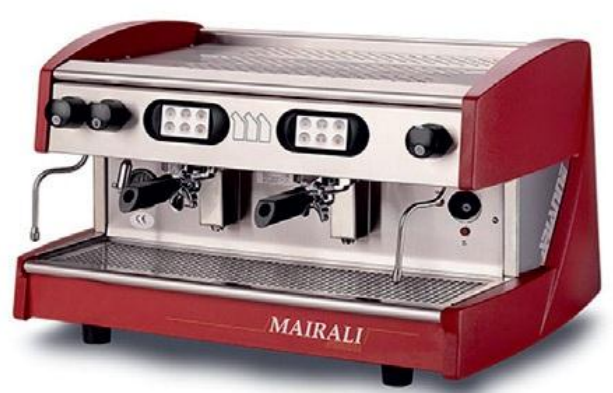

Maquina Expreso

- 2 grupos electrónica con diseño moderno y funcional.

- Facilidad para la limpieza.

- Interruptor general de 3 posiciones que facilita la puesta en marcha y el mantenimiento.

- Volumen de la caldera 12 litros.

- Potencia y consumo 2600 W 11.6 A.

- Peso 66 Kilos Dimensiones en cms: alto 46 fondo 57.6 ancho 77.2

- $\quad$ Precio 2.594.900

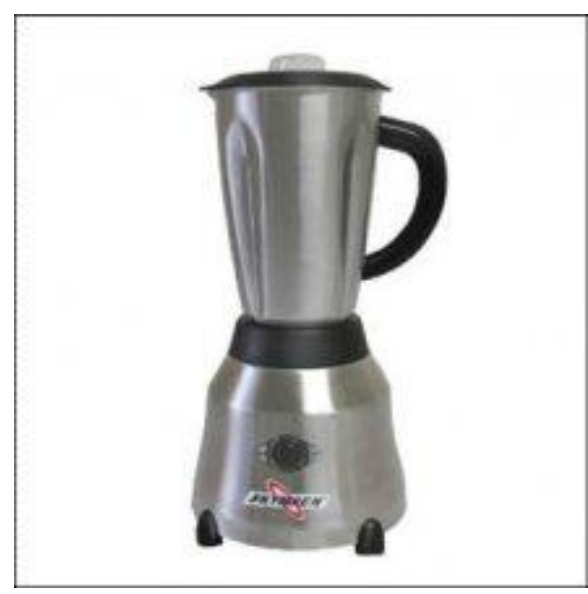

\section{Licuadora}

- marca SKYMSEN

- Vaso en acero inoxidable

- capacidad del vaso 1,5 litros,

- cuchilla, eje y mancal central hechos en acero inoxidable

- $\quad$ gabinete en metal pulido

- $\quad$ precio 250000

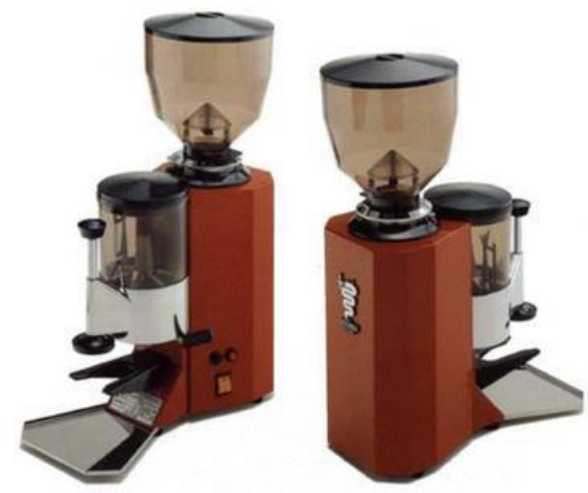

MOLINO DE CAFÉ

- color rojo

- molienda graduable

- Motor monofásico con protección térmica. Contador de porciones

- Capacidad: $6 \mathrm{Kg} . / \mathrm{hr}$

- Consumo: 250 vatios 110 voltios.

- Dimensiones: Ancho: 18 Alto: 55 Precio: 480000 


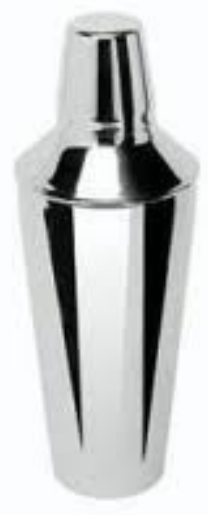

Coctelera en acero inoxidable

- 28 onzas

- Precio 28000

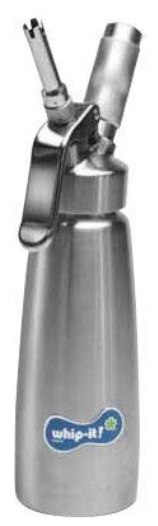

Dispensador De Crema Chantilly

- Contiene 10 Balas N2o

- Precio 259000

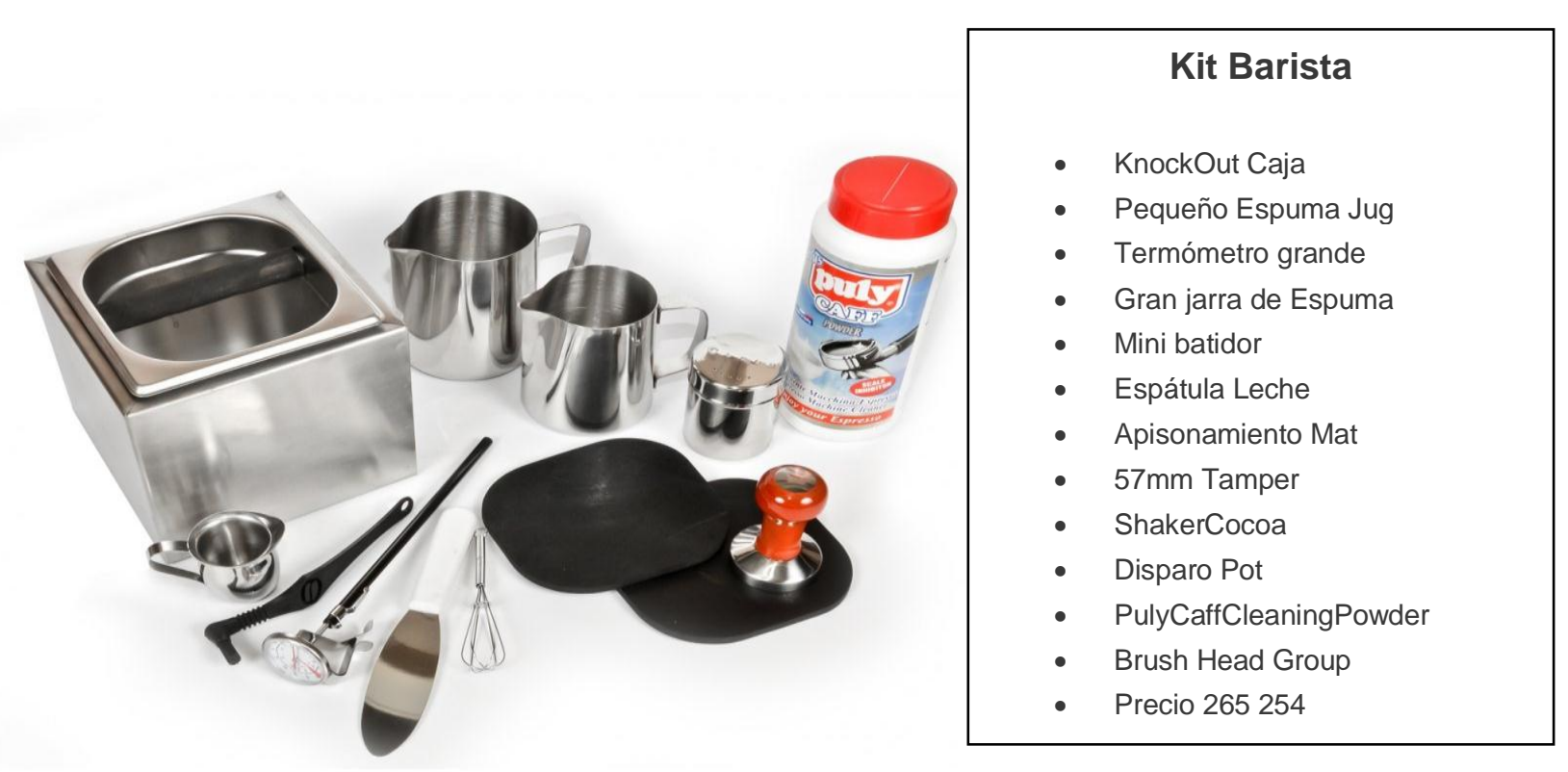




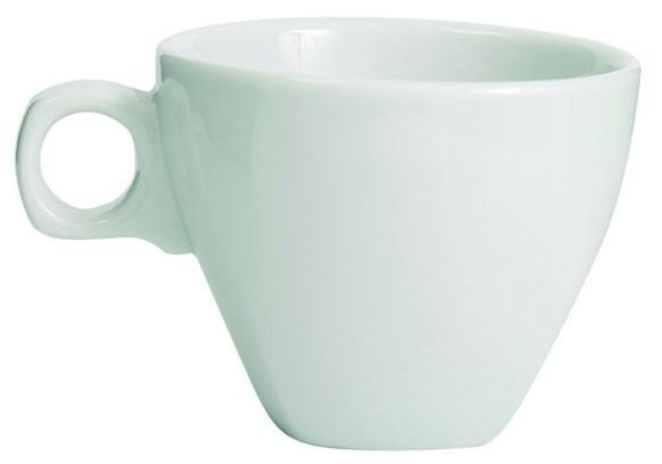

\section{Pocillo para café corona}

- Color blanco

- Porcelana

- De $100 \mathrm{cc}$

- Precio 4500

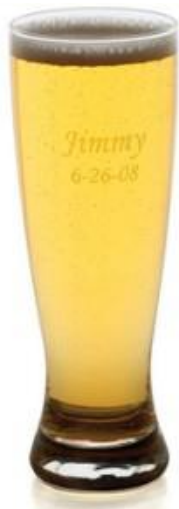

Vaso cervecero

- Material de vidrio

- Precio 3500

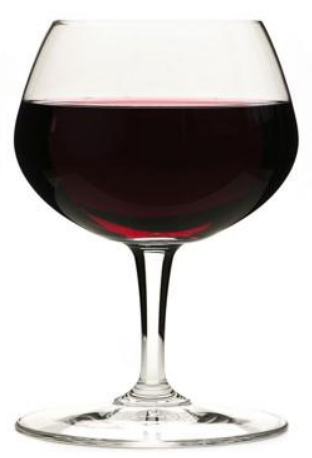

\section{Copa de vino}

Precio 4000 


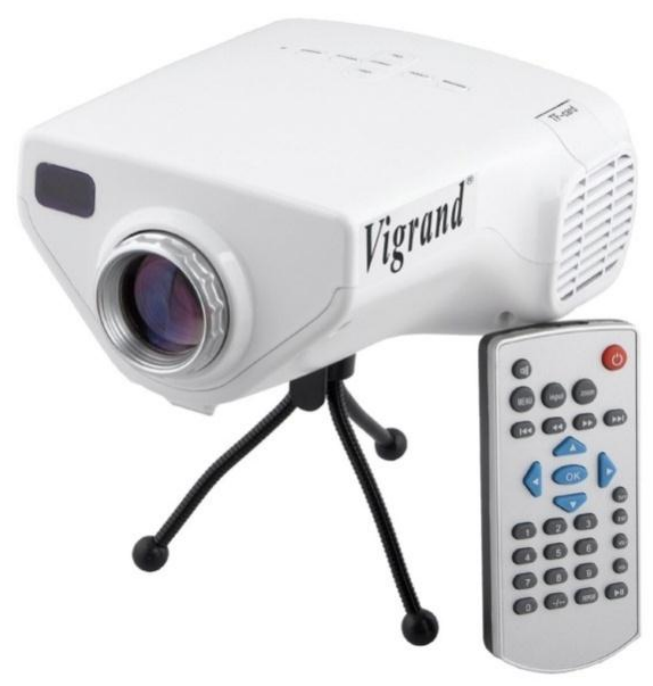

\section{MINI VIDEOBEAM}

- Multimedia portátil mini HD, LED, LCD

- Complatible con ipone, ipad. Samsung galaxy

- Contiene tripode en aluminio

- Precio 289000

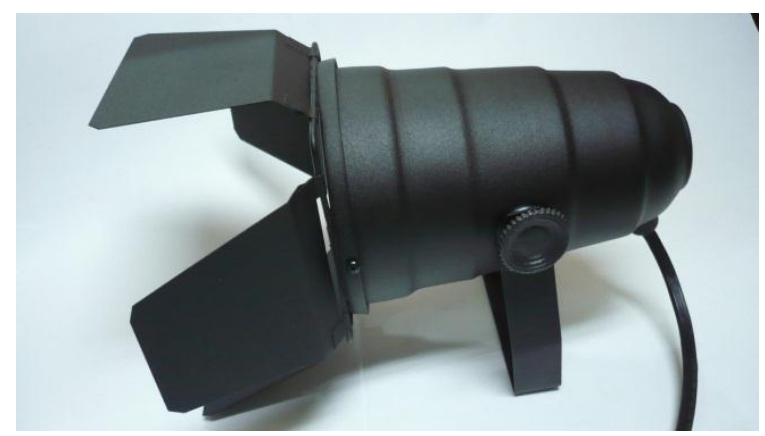

\section{Porta luz de teatro}

- Rosca tradicional E 27

- Pintura electro estática

- Aletas actualizables

- Precio: 35000

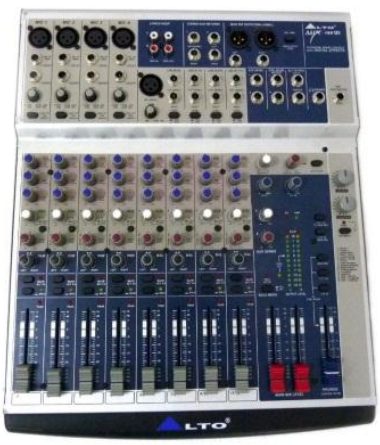

\section{Consola De Sonido}

Alto Amx-180fPrecio 249000 

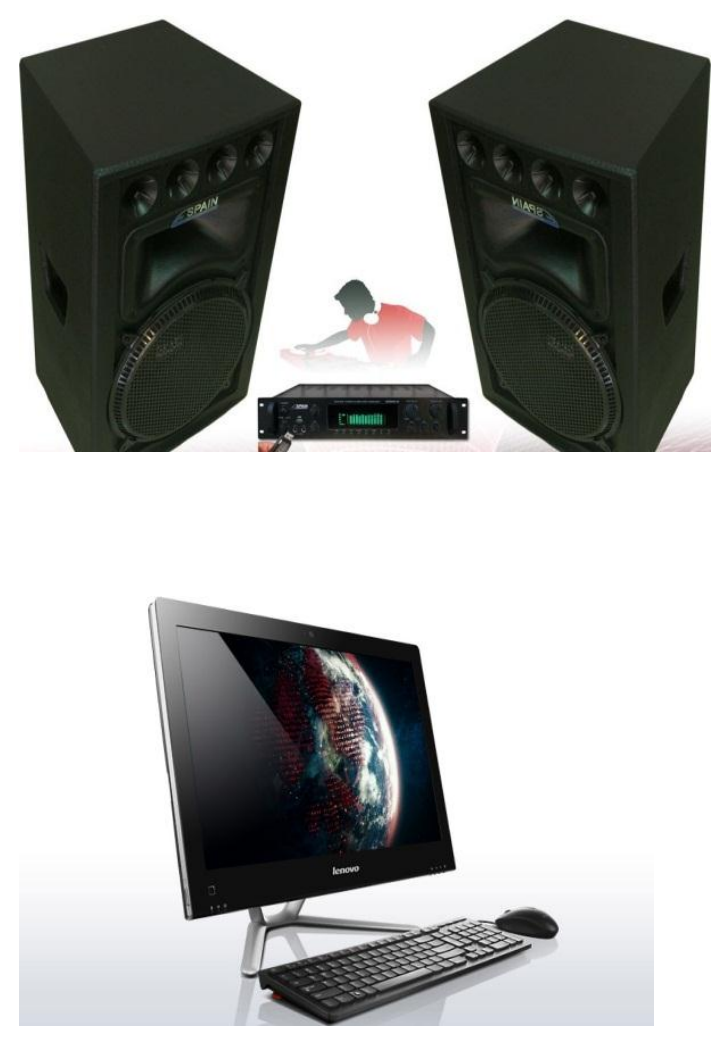

\section{Amplificador de sonido}

- amplificador spainsa 52 usb 1000

- cabina pasiva $1 \times 12$ parlante $500 \mathrm{w}$

- Precio: 550000

\section{COMPUTADOR TODO EN UNO}

- $\quad 3^{\circ}$ generación de procesadores Intel dual core

- Windows 8

- $4 \mathrm{~GB}$

- $\quad$ Intel® HD 2500 (integrados)

- $\quad 566$ x 197 x 427 mm (22,8 x 7,8 x 16,8")

- Cámara web HD de 720p integrada

- Pantalla LCD de 23? con retroiluminación LED (1600 x 900), 250 NITS

- Lectora/grabadora de DVD integrada

- 6 puertos USB (2 USB 3.0)

- $\quad$ Lector de tarjetas 6 en 1 (SD/SDHC/SDXC/MMC/MS/MS-Pro)

- Combo de conectores

- $\quad$ LAN 10/100/1000

- HDMI

- Disco de hasta 1 TB HDD (7.200 rpm)

- Ethernet 10/100/1.000 M

- $\quad 802.11 \mathrm{~b} / \mathrm{g} / \mathrm{n} \mathrm{Wi}-\mathrm{Fi}$

- $\quad$ Precio: 1494857

Además, para el servicio al cliente se compran 10 mesas de cuatro puestos cada una a 80000, 4 sillas para barra de 35000 y dos sofás de 40000 .

Análisis de normas ISO aplicadas a los procesos. Las normas Icontec que se implementarán en el centro de acoplamiento cultural, son las normas ISO 9000, la cual estandariza la gestión de los procesos sobre los servicios que se ofrecen, consiguiendo un mayor control sobre ellos. La ISO 20001 en la que se rigen todas las instituciones que se dedique a la comercialización de productos alimenticios. 
Descripción de insumos. Los insumos utilizados para la elaboración de bebidas, el más importante el café ya que de este, es la base para la elaboración de toda la variedad de cafés.

Tabla 13.

Descripción de insumos.

\begin{tabular}{|c|c|c|c|c|}
\hline Insumo & Precio & Cantidad ofrecida & Vida útil aprox & $\begin{array}{l}\text { costo por } \mathrm{ml} \mathrm{o} \\
\mathrm{gr}\end{array}$ \\
\hline Café especial origen & 60000 & 2500 gramos & 2 meses & 12 \\
\hline Leche entera Parmalat & 14000 & $\begin{array}{l}6 \text { bolsas de } 1100 \\
\text { mililitros }\end{array}$ & 6 meses & 2 \\
\hline Crema de leche & 7100 & 1100 mililitros & 2 meses & 6 \\
\hline Leche condensada & 8200 & 1100 mililitros & 2 meses & 7 \\
\hline Crema chantilly & 8000 & 1000 gramos & 6 meses & 8 \\
\hline Azúcar & 3500 & $\begin{array}{l}200 \text { unidades } x \\
5 \text { gramos }\end{array}$ & 2 meses & 18 \\
\hline Vino & 25000 & Botella 750cc & N/A & 33 \\
\hline Esencias de sabores & 6500 & Botella $500 \mathrm{cc}$ & 6 meses & 13 \\
\hline Galletas mini & 6000 & 12 paquetes & 4 meses & 17 \\
\hline Helado & 15000 & 5 litros & 2 meses & 3 \\
\hline Cerveza & 33000 & $\begin{array}{l}\text { Canasta de } 30 \\
\text { botellas } 320 \mathrm{cc}\end{array}$ & N/A & 1100 \\
\hline Frutas & 4000 & 500 gramos & 5 días & 4000 \\
\hline varierades de tragos & 30000 & $1000 \mathrm{ml}$ & & 30 \\
\hline agua & 1501 & $1 \mathrm{~m} 3$ & 150.132 & 1.501320 \\
\hline
\end{tabular}

Fuente. Autoras

Distribución de la planta. La distribución de la planta será de la siguiente manera un área de 86 m cuanta con una tarima, dos baños, la cocina y la barra. 
Figura 24. Plano bar.

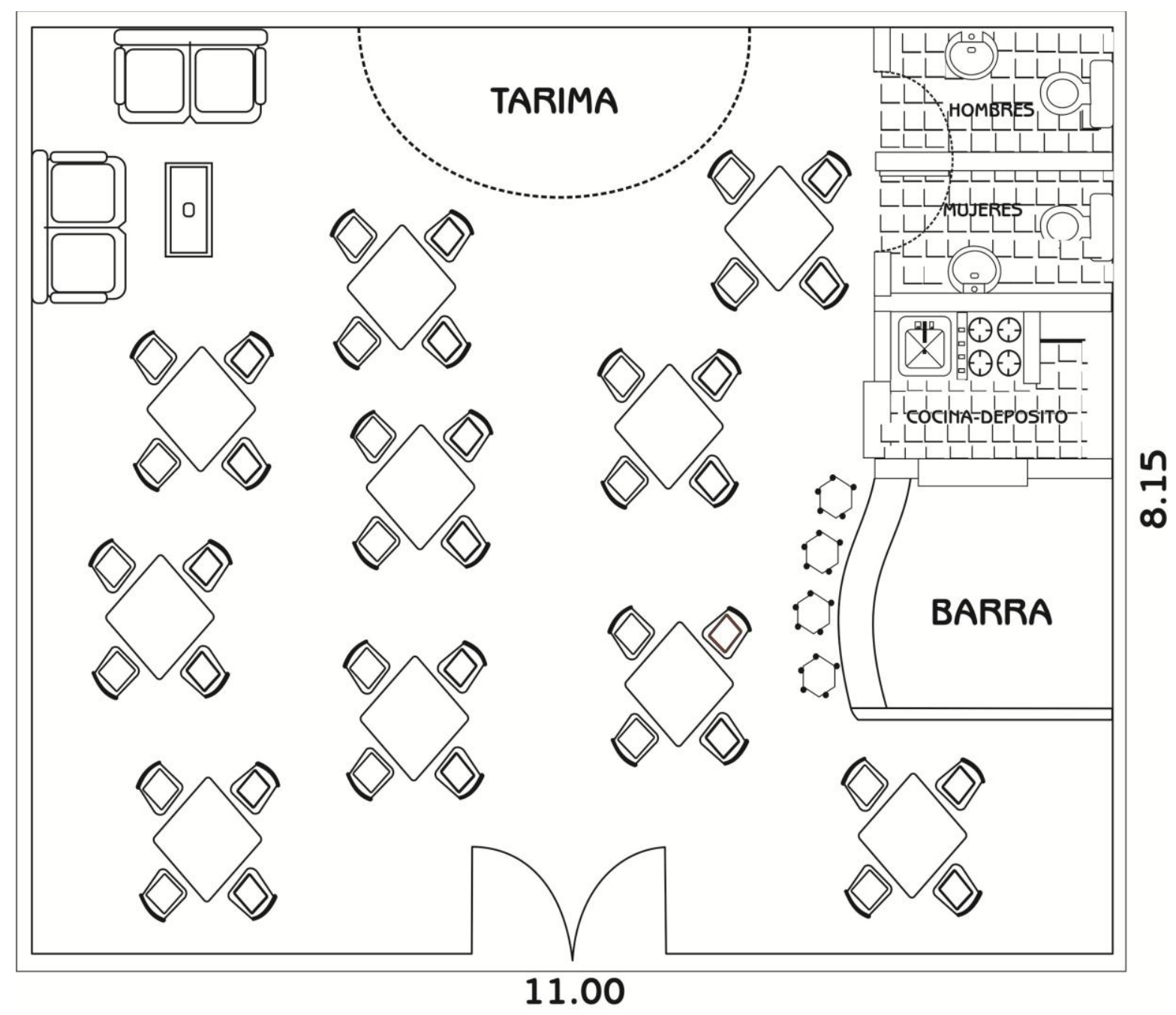

Fuente. Autoras

Para el local se debe pagar 2.000 .000 para la adecuación del lugar, y se paga 600.000, de arriendo mensual.

\section{Análisis Ambiental}

Marco teórico. El estudio de impacto ambiental es el instrumento básico para la toma de decisiones sobre los proyectos, obras o actividades que requieren licencia ambiental y se exigirá en todos los casos en que se requiera licencia ambiental de acuerdo con la ley y este reglamento. 
Metodología del análisis ambiental. Identificar y describir los efectos que genera la producción sobre los componentes ambientales como suelo, agua, fauna, flora, y paisaje, intereses comerciales salud de las personas, entre otros. Existen diferentes tipos de herramientas para la evaluación del impacto ambiental.

\section{Determinación del impacto ambiental.}

Figura 25. Sistema de gestión medioambiental.

\section{SGMA \\ (Sistema de gestión medioambiental)}

Disminuir casi en totalidad

la utilización de vasos y

platos desechables

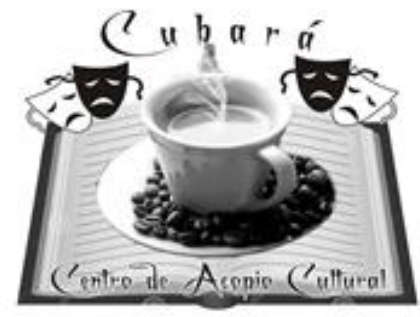

Ofrecer productos a base

de café, con insumos

$100 \%$ naturales de

excelente calidad

\footnotetext{
Ofrecer bebidas a base de café, mientras disfrutan de un ambiente agradable, manifestaciones artísticas y libros que brinden conocimiento.
}

Fuente. Autoras.

\section{Organización y Aspectos Administrativos}

\section{Marco teórico y conceptual de los aspectos administrativos y organizacionales}

Para un negocio, no solamente restaurantes, sino también en toda clase de industria, lo más importante e indispensable es el recurso humano. Las personas a parte de hacer su trabajo, son el alma de toda organización, puesto que hacen lo que no puede hacer cualquier 
máquina, darle vida a la compañía. Por eso es necesario e indispensable, mantener el equilibrio entre las diferentes áreas de la organización, hacer que el trabajador se sienta a gusto con su trabajo, para que preste un mejor servicio y esto se vea reflejado en su trabajo y en la satisfacción del cliente. Los proveedores, también son un recurso importante dentro de toda organización su buen trato y manejo hacen que se sienta bien para de esta forma también conseguir precios más bajos, mejor calidad y fidelidad.

\section{Metodología utilizada para la formulación de los aspectos administrativos yorganizacionales}

Para la formulación de los aspectos administrativos y organizacionales, se realizan los factores que afectan el mercado interno y externo, para encontrar la forma de diferenciar la idea de negocio de nuestros competidores, para aplicar la mejor estrategia de mercado, promoción y el personal necesario para el funcionamiento del negocio.

\section{Estructura orgánica y funciones a nivel de áreas}

El centro de acoplamiento cultural como prestador de servicios de cafetería y culturales debe contar con una área administrativa, una área de producción y servicio al cliente, un área de gestión cultural y un área de financiera.

Figura 26. Organigrama.

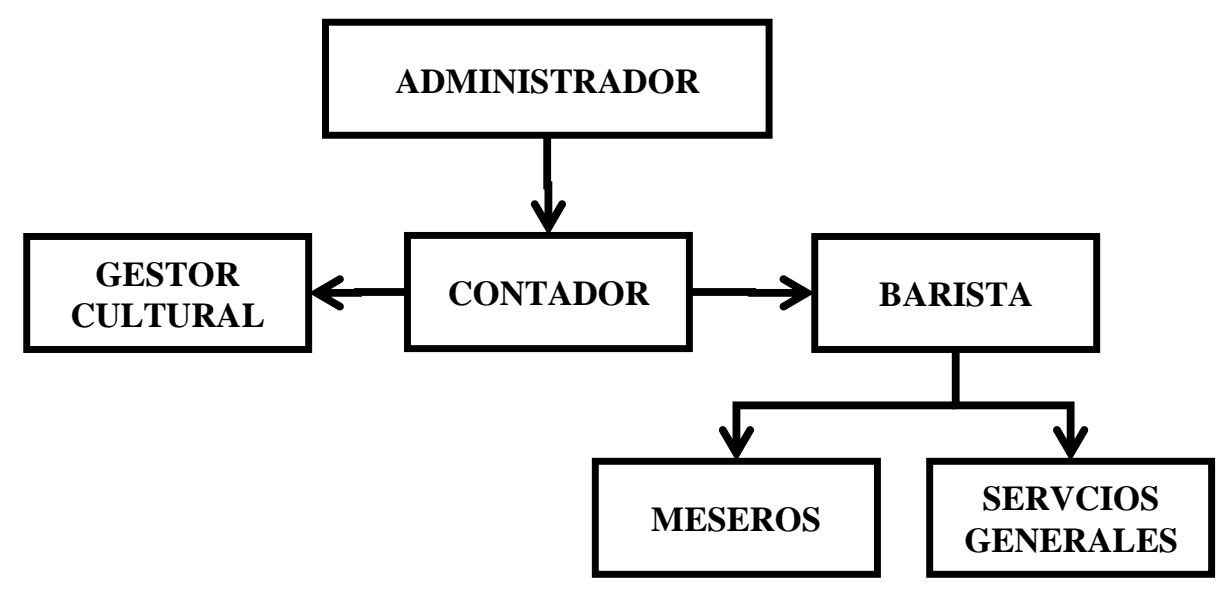

Fuente. Autoras. 


\section{Área administrativa}

- Las funciones que se deben tener para el área administrativa son:

- Representación legal de la sociedad y el centro cultural

- Toma de decisiones y solución de conflictos internos y externos dentro del centro de acoplamiento cultural

- Dirigir, evaluar y controlar el cumplimiento de los diferentes procesos de cada una de las actividades.

- Diseñar objetivos y estrategias de innovación, para atraer clientes.

\section{Área de Producción y Servicio al Cliente}

- Elaborar las diferentes bebidas ofrecidas a los clientes

- Asegurar que los clientes estén satisfechos con atención de respeto, amabilidad y cordialidad.

- Garantizar la fidelidad de los clientes y siga participando de las actividades y continúen adquiriendo los servicios de cafetería

- Recepción y verificación de la materia prima

- Control y mantenimiento de la maquinaria utilizada para la elaboración de las bebidas

- Garantizar orden, limpieza del establecimiento y los utensilios utilizados para el servicio a la mesa

\section{Área de Gestión Cultural}

- Organizar los eventos culturales dentro del centro cultural

- Invitar a los artistas a participar de acuerdo a las manifestaciones artísticas que se organicen 
- Estar a la vanguardia de las diferentes tendencias culturales del sector

- Garantizar a los artistas el cumplimiento sus necesidades

\section{Área Financiera}

- Realizar la contabilidad del centro de acoplamiento cultural

- Controlar el flujo de entradas y salidas de efectivo

- Garantizar que los estados financieros sean confiables y efectivos para lo toma de decisiones

Tabla 14.

Planta de cargos requerida.

Planta de Personal

\begin{tabular}{lllll}
\hline Área & Cargo & $\begin{array}{l}\text { Nivel } \\
\text { ocupacional }\end{array}$ & $\begin{array}{l}\text { Número } \\
\text { personas }\end{array}$ & $\begin{array}{l}\text { de } \\
\text { Adminel } \\
\text { académico }\end{array}$ \\
\hline Producción & Gerente & Directivo & 1 & Profesional \\
Servicio al Cliente & Mesero & Asistente & 2 & Técnico \\
\cline { 2 - 5 } & Gestor & Asistente & 1 & Técnico \\
\hline Gestión Cultural & Supervisor & 2 & Técnico \\
\hline Financiera & Contador & Directivo & 1 & Profesional \\
\hline
\end{tabular}

Fuente. Autoras. 
Tabla 15.

Descripción de funciones y perfiles a nivel de cargo.

\section{Descripción de Cargos}

\begin{tabular}{|c|c|c|}
\hline Cargo & Descripción del Funciones & Perfil del Aspirante \\
\hline Gerente & $\begin{array}{l}\text { Dirigir y coordinar todas las actividades y } \\
\text { los recursos a través del proceso de } \\
\text { planeamiento, organización, dirección, y } \\
\text { control a fin de lograr los objetivos } \\
\text { establecidos. Representar al café-cultura } \\
\text { frente a terceros. }\end{array}$ & $\begin{array}{l}\text { profesional en administración } \\
\text { de empresas }\end{array}$ \\
\hline Barista & $\begin{array}{l}\text { Control de los productos y bienes de la } \\
\text { barra. Elaboración de las distintas bebidas } \\
\text { especialmente en bebidas a base de café, } \\
\text { Control de higiene. }\end{array}$ & $\begin{array}{l}\text { Técnico en elaboración de } \\
\text { bebidas de café y servicio a la } \\
\text { mesa }\end{array}$ \\
\hline Mesero & $\begin{array}{l}\text { Asegurar que los clientes estén satisfechos } \\
\text { con atención de respeto, amabilidad y } \\
\text { cordialidad. } \\
\text { Garantizar la fidelidad de los clientes y } \\
\text { siga participando de las actividades y } \\
\text { continúen adquiriendo los servicios de } \\
\text { cafetería } \\
\text { Recepción de pedidos }\end{array}$ & $\begin{array}{l}\text { Técnico en servicio a la mesa } \\
\text { y servicio al cliente }\end{array}$ \\
\hline Gestor & $\begin{array}{l}\text { Organizar los eventos culturales dentro del } \\
\text { centro cultural, Invitar a los artistas a } \\
\text { participar de acuerdo a las } \\
\text { manifestaciones artísticas que se } \\
\text { organicen, Garantizar a los artistas el } \\
\text { cumplimiento de las necesidades de los } \\
\text { artistas invitados. }\end{array}$ & $\begin{array}{l}\text { Técnico en organización de } \\
\text { eventos }\end{array}$ \\
\hline Contador & $\begin{array}{l}\text { Recopilar, clasificar y registrar } \\
\text { sistemáticamente, ordenada } \\
\text { oportunamente los hechos económicos de } \\
\text { acuerdo a los principios contables, } \\
\text { normas legales y tributarias de las } \\
\text { operaciones contables de la empresa, con } \\
\text { el propósito de tener una información } \\
\text { financiera real, razonable y oportuna con } \\
\text { el fin de facilitar los controles, análisis y } \\
\text { toma de decisiones. }\end{array}$ & profesional en contabilidad \\
\hline
\end{tabular}

Fuente. Autoras. 


\section{Función de planeación corporativa}

Misión. Ofrecer a los clientes las mejores bebidas de café, aplicando un factor diferenciador como la gestión y promoción de manifestaciones artísticas para lograr un ambiente agradable y acogedor en la prestación del servicio

Visión. Ser reconocidos como el mejor lugar en la ciudad de Tunja de esparcimiento cultural, como gestores y promotores de manifestaciones artísticas mientras los clientes disfrutan de las más deliciosas bebidas de café.

\section{Objetivos}

\section{Objetivos a largo plazo}

- Lograr un posicionamiento en el mercado como uno de los gestores culturales más conocidos de la ciudad por medio de la captación de artistas municipales.

- Lograr una barra especializada de cafés apta para la competencia de mercados.

- Captar año tras año un $1.19 \%$ de la demanda.

\section{Objetivos a corto y mediano plazo}

- Aumentar el número de asistentes al café cultural.

- Dar a conocer la empresa, por medio de estrategias de marketing al ámbito local.

\section{Valores Corporativos}

Los valores que identifican al Café Cultural Cubara, son los siguientes:

- Ética: Actuar dentro de una concepción humanística, responsable y justa con los miembros de la sociedad.

- Compromiso: Trabajar con profesionalidad y honestidad, bajo los lineamientos legales, con el fin de mejorar la calidad de vida y crecimiento de nuestros colaboradores y de la ciudad, contribuyendo de esta forma al desarrollo del país. 
- Equidad: En el manejo de las relaciones laborales con nuestros colaboradores y relaciones comerciales con nuestros clientes y proveedores, con el fin de promover un ambiente digno y justo en el ambiente interno y externo de la compañía.

- Calidad: Realizar eficaz y eficientemente cada una de las labores que permiten la plena satisfacción del cliente.

Logo

Figura 27. Logo empresa.

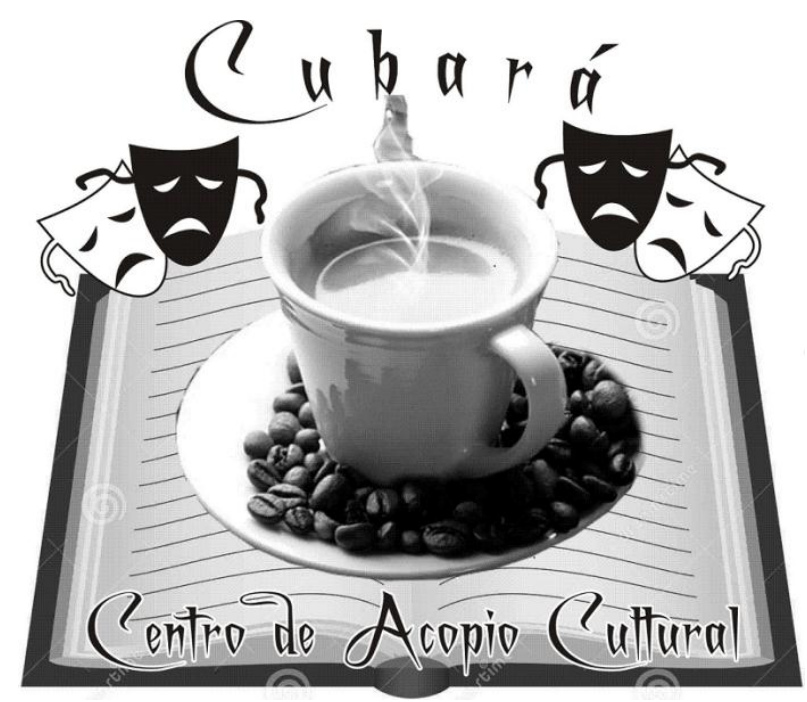

Fuente. Autores.

Política de Calidad. Nuestro compromiso fundamental es ofrecer productos y servicios que superen las expectativas de nuestros clientes, para de esta forma generar rentabilidad, bienestar a nuestros empleados y respeto al medio ambiente, trabajando siempre bajo las normas éticas y de mejora continua. 
Función de recursos humanos: sistemas de reclutamiento, remuneración, desarrollo, bienestar social, y relaciones laborales.

Selección, contratación y pago de nomina. El proceso de contratación inicia identificando los requerimientos que tiene la empresa a la hora de contratar personal administrativo y operario solicitado para desempeñar labores de prestación de servicio, de acuerdo a los requisitos del cliente y principalmente a las condiciones propias del café cultural. De la selección del personal depende la calidad y eficiencia de los servicios prestados.

Proceso de selección. El proceso de selección se desarrollara teniendo en cuenta los perfiles, necesidades y requisitos establecidos por el Café cultural para el área administrativa, en el área operativa contaremos con el apoyo de entidades de educación técnica tales como el SENA y se hará de la siguiente manera:

- Se hará un filtro con las hojas de vidas recibidas

- Se hará una entrevista para corroborar la información descrita en las hojas de vida

- Se hará una prueba acerca de la experiencia laboral

- Se prosigue a seleccionar el personal idóneo para desempeñarse en el Café cultural.

Contratación. Se determinara tipo de contrato clausulas especiales del contrato tales como confidencialidad, duración del contrato, derechos y obligaciones del trabajador y el empleador, forma de pago, disponibilidad de tiempo.

\section{Tipo de contrato manejado.}

Contrato término fijo. Este tipo de contrato podrá prorrogarse por tres (3) veces por término igual o inferior, a partir de la cuarta prórroga el término será mínimo un (1) año, los trabajadores tendrán derecho al pago de vacaciones y prima de servicios en proporción 
al tiempo laborado. Debe constar por escrito.

Cualquiera de las partes puede dar por terminado el contrato dando aviso a la otra con una anticipación mayor a treinta (30) días de la fecha de vencimiento del periodo contratado, si este aviso no se da o se da con una anticipación menor a treinta (30) días el contrato se prórroga por un periodo igual al inicial (lared.com.co).

Capacitación del personal. Se hará una capacitación cada 3 meses para todos los integrantes del Café cultural, con el fin de mejorar la eficiencia de la empresa, motivar al personal, mejorar la comunicación de la organización, generar sentido de pertenencia y mejorar el clima organizacional.

En las capacitaciones se abordan temas relacionados a higiene y seguridad, prevención de enfermedades y accidente laborales teniendo en cuenta las características riesgo propio de cada una de las actividades que desempeñan nuestro personal operario y administrativo.

La capacitación del personal se hará por medio de folletos, conferencias, cursos y se complementara material gráfico, medios audiovisuales y carteles que indiquen medidas de higiene y seguridad.

Política de salud ocupacional. El centro de acoplamiento cultural Cubara se compromete a alcanzar y mantener los niveles más altos de bienestar físico y social de sus trabajadores, logrando su desarrollo integral, por medio de la prevención y corrección de todos aquellos aspectos que en el ambiente laboral, puedan generar efectos nocivos a los trabajadores.

El centro de acoplamiento cultural Cubara espera que con éste compromiso se realicen todas las actividades que garantizan la salud de los trabajadores obteniéndose de 
forma simultanea el más alto nivel de eficiencia, compromiso individual, colectivo y productividad de quienes laboran en esta compañía.

Esta política es diseñada con el propósito de prevenir las enfermedades profesionales y los accidentes de trabajo, debido a que afectan las condiciones normales de productividad en la organización, incidiendo negativamente en el recurso humano y el ambiente en el que este se desenvuelve a nivel laboral, social y familiar.

La enfermedad profesional es todo estado patológico que se produce como consecuencia obligada directa de la labor desempeñada o del medio en que ha laborado y que está catalogada por el gobierno nacional según el decreto 2566 de 2009, igualmente es enfermedad profesional aquella que demuestre relación (causa - efecto).

El accidente de trabajo es todo suceso repentino que sobreviene con causa del trabajo y que produce en el trabajador una lesión orgánica, una perturbación funcional, una invalidez o la muerte. Es también accidente de trabajo el que sucede fuera del lugar y horario, siempre y cuando esté cumpliendo una orden del empleador.

La empresa se regirá por la ley 100 de Seguridad Social y los decretos 614/1984 y el 1295/1994 que obligan al empleador a asegurar a sus trabajadores contra los riesgos profesionales y que desarrollen e implementen el Programa de Salud Ocupacional.

Evaluación de desempeño. Con la evaluación de desempeño se pretende medir el rendimiento y grado de eficiencia con que el personal desarrolla las actividades propias de su cargo, grado de responsabilidad y compromiso con el Café cultural.

Para medir el grado de eficiencia de sus operarios el Café cultural manejara con sus clientes un cuestionario con una serie de preguntas acerca de la calidad del servicio prestado, grado de satisfacción, eficiencia en el desarrollo de las labores. 
Función de mercadeo: el plan de mercados, sistemas de divulgación y promoción del bien o servicio, sistema de ventas.

El plan de mercado que se pretende manejar es la divulgación y promoción por cadenas radiales y periódicos, también se manejara un brochure con la información pertinente a cada uno de las puestas en escena que se realizaran en el centro de acoplamiento cultural.

\section{Función de servicios administrativos: seguridad y mantenimiento de instalaciones}

Las instalaciones donde se pondrá en funcionamiento el Centro de acoplamiento cultural Cubara cuenta con una planta en donde se manejaran equipos materiales que abarcan tanto la maquinaria de producción como los muebles y enseres por consiguiente es necesario tomar servicios por medio de contrato outsourcing con una empresa de seguridad, que brinde la protección a dichos equipos para evitar posibles hurtos.

En cuanto al mantenimiento y cuidado de instalaciones, se tomarán también servicios por medio de contrato de outsourcing para realizar todas las tareas relacionadas con el aseo de las instalaciones, con el ánimo de brindar un ambiente óptimo tanto a los trabajadores como a los clientes.

Función financiera: sistemas de contabilidad y presupuestos, políticas de financiamiento e inversiones

Tabla 16.

Nomina Contable.

\begin{tabular}{|c|c|c|c|c|c|c|c|c|c|c|c|c|c|}
\hline & \multicolumn{9}{|c|}{ DEVENGADO } & \multicolumn{3}{|c|}{ DEDUCIDO } & \multirow{2}{*}{$\begin{array}{l}\text { NETOA } \\
\text { PAGAR }\end{array}$} \\
\hline \begin{tabular}{|l|l} 
NOMBRE/ & D \\
DOCUMENTO & T \\
\end{tabular} & $\begin{array}{l}\text { DIAS } \\
\text { TRABAJADOS }\end{array}$ & SALARIO BASE & $\begin{array}{l}\text { AUX. } \\
\text { TRANSPORTE }\end{array}$ & SALARIO & $\begin{array}{l}\text { H.E.D } \\
25 \% \\
\end{array}$ & $\begin{array}{l}\text { H.E.N } \\
75 \% \\
\end{array}$ & R.N & & \begin{tabular}{|l} 
TOTAL \\
DEVENGADO
\end{tabular} & SALUD & PENSION & $\begin{array}{l}\text { FONDO } \\
\text { SOLIDARIO }\end{array}$ & \\
\hline administrador & 30 & $\$ 890,000$ & $\$ 72,500$ & $\$ 962,500$ & & & & & $\$ 962,500$ & $\$ 38,500$ & $\$ 38,500$ & & 885,500 \\
\hline mesero & 30 & $\$ \quad 616,000$ & $\$ 72,500$ & 688,500 & & & & & $\$ \quad 688,500$ & $\$ 27,540$ & $\$ \quad 27,540$ & & 633,420 \\
\hline mesero & 30 & $\$ \quad 616,000$ & $\$ \quad 72,500$ & 688,500 & & & & & $\$ \quad 688,500$ & $\$ 27,540$ & $\$ \quad 27,540$ & & 633,420 \\
\hline barra & 30 & $\$ \quad 616,000$ & $\$ \quad 72,500$ & 688,500 & & & & & $\$ \quad 688,500$ & $\$ 27,540$ & 27,540 & & 633,420 \\
\hline & & & $\$ \quad 72,500$ & 72,500 & & & & & $\$ 72,500$ & $\$ \quad 2,900$ & 2,900 & & 66,700 \\
\hline TOTAL & 120 & $\$ 2,738,000$ & $\$ 362,500$ & $\$ 3,100,500$ & $\$$ & $\$$ & $\$$ & - & $\$ 3,100,500$ & $\$ 124,020$ & $\$ 124,020$ & $\$$ & $\$ 2,852,460$ \\
\hline
\end{tabular}

Fuente. Autoras. 
Pautas para garantizar la sostenibilidad del proyecto una vez entre en operación.

- Evaluación constante de cada uno de los procesos que se desarrollen en el Centro de acoplamiento cultural.

- Planeación estratégica.

- Evaluación constante del mercado, la competencia y los factores externos, tales como las leyes gubernamentales, los avances tecnológicos, etc.

- Crear una cultura organizacional que fomente el trabajo en equipo y el compromiso por parte de los trabajadores del café.

- Cumplir con todo lo relacionado con toda la parte legal y de impuestos que la empresa le corresponda

\section{Marco Legal del Proyecto}

\section{Definición del tipo de organización}

El centro de Acoplamiento Cultural Cubara será una sociedad anónima simplificada (S.A.S). Este tipo de sociedad fue creada por la Ley 1258 de 2008 de Sociedades por Acciones Simplificadas SAS, introduce un tipo social híbrido, con autonomía, tipicidad definida y con una regulación vinculada al régimen general de las sociedades. Este nuevo tipo de sociedad brinda las ventajas de las sociedades anónimas y les permite diseñar mecanismos de direccionamiento de sus empresas de acuerdo a las necesidades.(Servicio Nacional de Aprendizaje) 


\section{Preparación de estatutos, minutas de escrituras de constitución. Centro de Acoplamiento Cultural Cubarasas}

\section{Acto Constitutivo}

Diana Catalina Archila Peñalosa, de nacionalidad Colombiana, identificada con C.C. 1049618722, domiciliado en la ciudad de Tunja y Manuela Fernanda Forero Mejía de nacionalidad Colombiana, identificado con C.C. 1049622952, domiciliado en la ciudad de Tunja, declaran -previamente al establecimiento y a la firma de los presentes estatutos, haber decidido constituir una sociedad por acciones simplificada denominada CUBARA SAS, para realizar cualquier actividad civil o comercial lícita, por término indefinido de duración, con un capital suscrito de $\$ 18.000 .000$, dividido en 3600 acciones ordinarias de valor nominal de \$5.000 cada una, que han sido liberadas en su (totalidad o en el porcentaje correspondiente), previa entrega del monto correspondiente a la suscripción al representante legal designado y que cuenta con un único órgano de administración y representación, que será el representante legal designado mediante este documento.

Una vez formulada la declaración que antecede, el suscrito ha establecido, así mismo, los estatutos de la sociedad por acciones simplificada que por el presente acto se crea.

\section{Estatutos}

\section{Capítulo I}

\section{Disposiciones generales}

Artículo $\mathbf{1}^{\mathbf{0}}$. Forma.- La compañía que por este documento se constituye es una sociedad por acciones simplificada, de naturaleza comercial, que se denominará CUBARA SAS, regida por las cláusulas contenidas en estos estatutos, en la Ley 1258de 2008 y en las demás disposiciones legales relevantes. 
En todos los actos y documentos que emanen de la sociedad, destinados a terceros, la denominación estará siempre seguida de las palabras: "sociedad por acciones simplificada" o de las iniciales "SAS".

Artículo $2^{\circ}$. Objeto social.- La sociedad tendrá como objeto principal la creación, gestión y promoción de las artes escénicas. Así mismo, podrá realizar cualquier otra actividad económica lícita tanto en Colombia como en el extranjero.

La sociedad podrá llevar a cabo, en general, todas las operaciones, de cualquier naturaleza que ellas fueren, relacionadas con el objeto mencionado, así como cualesquiera actividades similares, conexas o complementarias o que permitan facilitar o desarrollar el comercio o la industria de la sociedad.

Artículo 30. Domicilio.- El domicilio principal de la sociedad será la ciudad de TUNJA y su dirección para notificaciones judiciales será en Avenida Maldonado $N^{\circ} 27$ 63. La sociedad podrá crear sucursales, agencias o dependencias en otros lugares del país o del exterior, por disposición de la asamblea general de accionistas.

Artículo 4 . Término de duración.- El término de duración será indefinido.

\section{Capítulo II}

\section{Reglas sobre capital y acciones}

Artículo 50. Capital Autorizado.- El capital autorizado de la sociedad es de $\$ 18000000$ pesos moneda corriente, dividido en 3600 acciones de valor nominal de $\$ 5000$ pesos moneda corriente cada una.

Artículo 6 ${ }^{\circ}$. Capital Suscrito.- El capital suscrito inicial de la sociedad es de \$ 18 000000 pesos moneda corriente, dividido en 3600 acciones ordinarias de valor nominal de $\$ 5000$ pesos moneda corriente cada una. 
Artículo $7^{\circ}$. Capital Pagado.- El capital pagado de la sociedad es de \$ 18000000 pesos moneda corriente, dividido en 3600 acciones ordinarias de valor nominal de $\$ 5000$ pesos moneda corriente cada una.

Parágrafo. Forma y Términos en que se pagará el capital.- El monto de capital suscrito se pagará, en dinero efectivo, dentro de los 24 meses siguientes a la fecha de la inscripción en el registro mercantil del presente documento.

Artículo 8 ${ }^{\circ}$. Derechos que confieren las acciones.- En el momento de la constitución de la sociedad, todos los títulos de capital emitidos pertenecen a la misma clase de acciones ordinarias. A cada acción le corresponde un voto en las decisiones de la asamblea general de accionistas.

Los derechos y obligaciones que le confiere cada acción a su titular les serán transferidos a quien las adquiriere, luego de efectuarse sucesión a cualquier título.

La propiedad de una acción implica la adhesión a los estatutos y a las decisiones colectivas de los accionistas.

Artículo $9^{\circ}$. Naturaleza de las acciones.- Las acciones serán nominativas y deberán ser inscritas en el libro que la sociedad lleve conforme a la ley. Mientras que subsista el derecho de preferencia y las demás restricciones para su enajenación, las acciones no podrán negociarse sino con arreglo a lo previsto sobre el particular en los presentes estatutos.

Artículo $\mathbf{1 0}^{\circ}$. Aumento del capital suscrito.- El capital suscrito podrá ser aumentado sucesivamente por todos los medios y en las condiciones previstas en estos estatutos y en la ley. Las acciones ordinarias no suscritas en el acto de constitución podrán ser emitidas 
mediante decisión del representante legal, quien aprobará el reglamento respectivo y formulará la oferta en los términos que se prevean reglamento.

Artículo $\mathbf{1 1}^{\circ}$. Derecho de preferencia.- Salvo decisión de la asamblea general de accionistas, aprobada mediante votación de uno o varios accionistas que representen cuando menos el setenta por ciento de las acciones presentes en la respectiva reunión, el reglamento de colocación preverá que las acciones se coloquen con sujeción al derecho de preferencia, de manera que cada accionista pueda suscribir un número de acciones proporcional a las que tenga en la fecha del aviso de oferta. El derecho de preferencia también será aplicable respecto de la emisión de cualquier otra clase títulos, incluidos los bonos, los bonos obligatoriamente convertibles en acciones, las acciones con dividendo preferencial y sin derecho a voto, las acciones con dividendo fijo anual y las acciones privilegiadas.

Parágrafo Primero.- El derecho de preferencia a que se refiere este artículo, se aplicará también en hipótesis de transferencia universal de patrimonio, tales como liquidación, fusión y escisión en cualquiera de sus modalidades. Así mismo, existirá derecho de preferencia para la cesión de fracciones en el momento de la suscripción y para la cesión del derecho de suscripción preferente.

Parágrafo Segundo.- No existirá derecho de retracto a favor de la sociedad.

Artículo $12^{\circ}$. Clases y Series de Acciones.- Por decisión de la asamblea general de accionistas, adoptada por uno o varios accionistas que representen la totalidad de las acciones suscritas, podrá ordenarse la emisión de acciones con dividendo preferencial y sin derecho a voto, con dividendo fijo anual, de pago o cualesquiera otras que los accionistas decidieren, siempre que fueren compatibles con las normas legales vigentes. Una vez 
autorizada la emisión por la asamblea general de accionistas, el representante legal aprobará el reglamento correspondiente, en el que se establezcan los derechos que confieren las acciones emitidas, los términos y condiciones en que podrán ser suscritas y si los accionistas dispondrán del derecho de preferencia para su suscripción.

Parágrafo.- Para emitir acciones privilegiadas, será necesario que los privilegios respectivos sean aprobados en la asamblea general con el voto favorable de un número de accionistas que represente por lo menos el $75 \%$ de las acciones suscritas. En el reglamento de colocación de acciones privilegiadas, que será aprobado por la asamblea general de accionistas, se regulará el derecho de preferencia a favor de todos los accionistas, con el fin de que puedan suscribirlas en proporción al número de acciones que cada uno posea en la fecha del aviso de oferta.

Artículo $\mathbf{1 3}^{\circ}$. Voto múltiple.- Salvo decisión de la asamblea general de accionistas aprobada por el $100 \%$ de las acciones suscritas, no se emitirán acciones con voto múltiple. En caso de emitirse acciones con voto múltiple, la asamblea aprobará, además de su emisión, la reforma a las disposiciones sobre quórum y mayorías decisorias que sean necesarias para darle efectividad al voto múltiple que se establezca.

Artículo $\mathbf{1 4}^{\circ}$. Acciones de pago.- En caso de emitirse acciones de pago, el valor que representen las acciones emitidas respecto de los empleados de la sociedad, no podrá exceder de los porcentajes previstos en las normas laborales vigentes.

Las acciones de pago podrán emitirse sin sujeción al derecho de preferencia, siempre que así lo determine la asamblea general de accionistas. 
Artículo 15 $^{\circ}$. Transferencia de acciones a una fiducia mercantil.- Los accionistas podrán transferir sus acciones a favor de una fiducia mercantil, siempre que en el libro de registro de accionistas se identifique a la compañía fiduciaria, así como a los beneficiarios del patrimonio autónomo junto con sus correspondientes porcentajes en la fiducia.

Artículo $16^{\circ}$. Restricciones a la negociación de acciones.- Durante un término de cinco años, contado a partir de la fecha de inscripción en el registro mercantil de este documento, las acciones no podrán ser transferidas a terceros, salvo que medie autorización expresa, adoptada en la asamblea general por accionistas representantes del $100 \%$ de las acciones suscritas. Esta restricción quedará sin efecto en caso de realizarse una transformación, fusión, escisión o cualquier otra operación por virtud de la cual la sociedad se transforme o, de cualquier manera, migre hacia otra especie asociativa.

La transferencia de acciones podrá efectuarse con sujeción a las restricciones que en estos estatutos se prevén, cuya estipulación obedeció al deseo de los fundadores de mantener la cohesión entre los accionistas de la sociedad.

Artículo 17 $^{\mathbf{0}}$. Cambio de control.- Respecto de todos aquellos accionistas que en el momento de la constitución de la sociedad o con posterioridad fueren o llegaren a ser una sociedad, se aplicarán las normas relativas a cambio de control previstas en el artículo 16 de la Ley 1258 de 2008.

\section{Capítulo III}

\section{Órganos sociales}

Artículo 18\%. Órganos de la sociedad.- La sociedad tendrá un órgano de dirección, denominado asamblea general de accionistas y un representante legal La revisoría fiscal solo será provista en la medida en que lo exijan las normas legales vigentes. 
Artículo $1^{\circ}$. Sociedad devenida unipersonal.- La sociedad podrá ser pluripersonal o unipersonal. Mientras que la sociedad sea unipersonal, el accionista único ejercerá todas las atribuciones que en la ley y los estatutos se le confieren a los diversos órganos sociales, incluidos las de representación legal, a menos que designe para el efecto a una persona que ejerza este último cargo.

Las determinaciones correspondientes al órgano de dirección que fueren adoptadas por el accionista único, deberán constar en actas debidamente asentadas en el libro correspondiente de la sociedad.

Artículo 20 . Asamblea general de accionistas.- La asamblea general de accionistas la integran el o los accionistas de la sociedad, reunidos con arreglo a las disposiciones sobre convocatoria, quórum, mayorías y demás condiciones previstas en estos estatutos y en la ley.

Cada año, dentro de los tres meses siguientes a la clausura del ejercicio, el 31 de diciembre del respectivo año calendario, el representante legal convocará a la reunión ordinaria de la asamblea general de accionistas, con el propósito de someter a su consideración las cuentas de fin de ejercicio, así como el informe de gestión y demás documentos exigidos por la ley.

La asamblea general de accionistas tendrá, además de las funciones previstas en el artículo 420 del Código de Comercio, las contenidas en los presentes estatutos y en cualquier otra norma legal vigente.

La asamblea será presidida por el representante legal y en caso de ausencia de éste, por la persona designada por el o los accionistas que asistan. 
Los accionistas podrán participar en las reuniones de la asamblea, directamente o por medio de un poder conferido a favor de cualquier persona natural o jurídica, incluido el representante legal o cualquier otro individuo, aunque ostente la calidad de empleado o administrador de la sociedad.

Los accionistas deliberarán con arreglo al orden del día previsto en la convocatoria. Con todo, los accionistas podrán proponer modificaciones a las resoluciones sometidas a su aprobación y, en cualquier momento, proponer la revocatoria del representante legal.

Artículo 21ㅜ. Convocatoria a la asamblea general de accionistas.- La asamblea general de accionistas podrá ser convocada a cualquier reunión por ella misma o por el representante legal de la sociedad, mediante comunicación escrita dirigida a cada accionista con una antelación mínima de cinco (5) días hábiles.

En la primera convocatoria podrá incluirse igualmente la fecha en que habrá de realizarse una reunión de segunda convocatoria, en caso de no poderse llevar a cabo la primera reunión por falta de quórum.

Uno o varios accionistas que representen por lo menos el $20 \%$ de las acciones suscritas podrán solicitarle al representante legal que convoque a una reunión de la asamblea general de accionistas, cuando lo estimen conveniente.

Artículo $2^{\circ}$. Renuncia a la convocatoria.- Los accionistas podrán renunciar a su derecho a ser convocados a una reunión determinada de la asamblea, mediante comunicación escrita enviada al representante legal de la sociedad antes, durante o después de la sesión correspondiente. Los accionistas también podrán renunciar a su derecho de inspección por medio del mismo procedimiento indicado. 
Aunque no hubieren sido convocados a la asamblea, se entenderá que los accionistas que asistan a la reunión correspondiente han renunciado al derecho a ser convocados, a menos que manifiesten su inconformidad con la falta de convocatoria antes que la reunión se lleve a cabo.

Artículo 230. Derecho de inspección.- El derecho de inspección podrá ser ejercido por los accionistas durante todo el año. En particular, los accionistas tendrán acceso a la totalidad de la información de naturaleza financiera, contable, legal y comercial relacionada con el funcionamiento de la sociedad, así como a las cifras correspondientes a la remuneración de los administradores sociales. En desarrollo de esta prerrogativa, los accionistas podrán solicitar toda la información que consideren relevante para pronunciarse, con conocimiento de causa, acerca de las determinaciones sometidas a consideración del máximo órgano social, así como para el adecuado ejercicio de los derechos inherentes a las acciones de que son titulares.

Los administradores deberán suministrarles a los accionistas, en forma inmediata, la totalidad de la información solicitada para el ejercicio de su derecho de inspección.

La asamblea podrá reglamentar los términos, condiciones y horarios en que dicho derecho podrá ser ejercido.

Artículo $\mathbf{2 4}^{\mathbf{0}}$. Reuniones no presenciales.- Se podrán realizar reuniones por comunicación simultánea o sucesiva y por consentimiento escrito, en los términos previstos en la ley. En ningún caso se requerirá de delegado de la Superintendencia de Sociedades para este efecto.

Artículo 25․ Régimen de quórum y mayorías decisorias: La asamblea deliberará con un número singular o plural de accionistas que representen cuando menos la mitad más 
uno de las acciones suscritas con derecho a voto. Las decisiones se adoptarán con los votos favorables de uno o varios accionistas que representen cuando menos la mitad más uno de las acciones con derecho a voto presentes en la respectiva reunión.

Cualquier reforma de los estatutos sociales requerirá el voto favorable del $100 \%$ de las acciones suscritas, incluidas las siguientes modificaciones estatutarias:

(i) La modificación de lo previsto en el artículo 16 de los estatutos sociales, respecto de las restricciones en la enajenación de acciones.

(ii) La realización de procesos de transformación, fusión o escisión.

(iii) La inserción en los estatutos sociales de causales de exclusión de los accionistas o la modificación de lo previsto en ellos sobre el particular;

(iv) La modificación de la cláusula compromisoria;

(v) La inclusión o exclusión de la posibilidad de emitir acciones con voto múltiple; y

(vi) La inclusión o exclusión de nuevas restricciones a la negociación de acciones.

Parágrafo.- Así mismo, requerirá determinación unánime del 100\% de las acciones suscritas, la determinación relativa a la cesión global de activos en los términos del artículo 32 de la Ley 1258 de 2008

Artículo $26^{\circ}$. Fraccionamiento del voto: Cuando se trate de la elección de comités u otros cuerpos colegiados, los accionistas podrán fraccionar su voto. En caso de crearse junta directiva, la totalidad de sus miembros serán designados por mayoría simple de los votos emitidos en la correspondiente elección. Para el efecto, quienes tengan intención de postularse confeccionarán planchas completas que contengan el número total de miembros de la junta directiva. Aquella plancha que obtenga el mayor número de votos será elegida en su totalidad. 
Artículo $27^{\circ}$. Actas.- Las decisiones de la asamblea general de accionistas se harán constar en actas aprobadas por ella misma, por las personas individualmente delegadas para el efecto o por una comisión designada por la asamblea general de accionistas. En caso de delegarse la aprobación de las actas en una comisión, los accionistas podrán fijar libremente las condiciones de funcionamiento de este órgano colegiado.

En las actas deberá incluirse información acerca de la fecha, hora y lugar de la reunión, el orden del día, las personas designadas como presidente y secretario de la asamblea, la identidad de los accionistas presentes o de sus representantes o apoderados, los documentos e informes sometidos a consideración de los accionistas, la síntesis de las deliberaciones llevadas a cabo, la transcripción de las propuestas presentadas ante la asamblea y el número de votos emitidos a favor, en contra y en blanco respecto de cada una de tales propuestas.

Las actas deberán ser firmadas por el presidente y el secretario de la asamblea. La copia de estas actas, autorizada por el secretario o por algún representante de la sociedad, será prueba suficiente de los hechos que consten en ellas, mientras no se demuestre la falsedad de la copia o de las actas.

Artículo $\mathbf{2 8}^{\circ}$. Representación Legal.- La representación legal de la sociedad por acciones simplificada estará a cargo de una persona natural o jurídica, accionista o no, quien no tendrá suplentes, designado para un término de un año por la asamblea general de accionistas.

Las funciones del representante legal terminarán en caso de dimisión o revocación por parte de la asamblea general de accionistas, de deceso o de incapacidad en aquellos casos en que el representante legal sea una persona natural y en caso de liquidación privada 
o judicial, cuando el representante legal sea una persona jurídica.

La cesación de las funciones del representante legal, por cualquier causa, no da lugar a ninguna indemnización de cualquier naturaleza, diferente de aquellas que le correspondieren conforme a la ley laboral, si fuere el caso.

La revocación por parte de la asamblea general de accionistas no tendrá que estar motivada y podrá realizarse en cualquier tiempo.

En aquellos casos en que el representante legal sea una persona jurídica, las funciones quedarán a cargo del representante legal de ésta.

Toda remuneración a que tuviere derecho el representante legal de la sociedad, deberá ser aprobada por la asamblea general de accionistas.

Artículo $2^{\circ}$. Facultades del representante legal.- La sociedad será gerenciada, administrada y representada legalmente ante terceros por el representante legal, quien no tendrá restricciones de contratación por razón de la naturaleza ni de la cuantía de los actos que celebre. Por lo tanto, se entenderá que el representante legal podrá celebrar o ejecutar todos los actos y contratos comprendidos en el objeto social o que se relacionen directamente con la existencia y el funcionamiento de la sociedad.

El representante legal se entenderá investido de los más amplios poderes para actuar en todas las circunstancias en nombre de la sociedad, con excepción de aquellas facultades que, de acuerdo con los estatutos, se hubieren reservado los accionistas. En las relaciones frente a terceros, la sociedad quedará obligada por los actos y contratos celebrados por el representante legal.

Le está prohibido al representante legal y a los demás administradores de la sociedad, por sí o por interpuesta persona, obtener bajo cualquier forma o modalidad jurídica 
préstamos por parte de la sociedad u obtener de parte de la sociedad aval, fianza o cualquier otro tipo de garantía de sus obligaciones personales.

\section{Capítulo IV}

\section{Disposiciones Varias}

Artículo $30^{\circ}$. Enajenación global de activos.- Se entenderá que existe enajenación global de activos cuando la sociedad se proponga enajenar activos y pasivos que representen el cincuenta por ciento o más del patrimonio líquido de la compañía en la fecha de enajenación. La enajenación global requerirá aprobación de la asamblea, impartida con el voto favorable de uno o varios accionistas que representen cuando menos la mitad más una de las acciones presentes en la respectiva reunión. Esta operación dará lugar al derecho de retiro a favor de los accionistas ausentes y disidentes en caso de desmejora patrimonial.

Artículo $3^{\circ}$. Ejercicio social.- Cada ejercicio social tiene una duración de un año, que comienza el $1^{\circ}$ de enero y termina el 31 de diciembre. En todo caso, el primer ejercicio social se contará a partir de la fecha en la cual se produzca el registro mercantil de la escritura de constitución de la sociedad.

Artículo $32^{\circ}$. Cuentas anuales.- Luego del corte de cuentas del fin de año calendario, el representante legal de la sociedad someterá a consideración de la asamblea general de accionistas los estados financieros de fin de ejercicio, debidamente dictaminados por un contador independiente, en los términos del artículo 28 de la Ley 1258 de 2008. En caso de proveerse el cargo de revisor fiscal, el dictamen será realizado por quien ocupe el cargo.

Artículo $33^{\circ}$. Reserva Legal.- la sociedad constituirá una reserva legal que ascenderá por lo menos al cincuenta por ciento del capital suscrito, formado con el diez por ciento de las utilidades líquidas de cada ejercicio. Cuando esta reserva llegue al cincuenta por ciento 
mencionado, la sociedad no tendrá obligación de continuar llevando a esta cuenta el diez por ciento de las utilidades líquidas. Pero si disminuyere, volverá a apropiarse el mismo diez por ciento de tales utilidades, hasta cuando la reserva llegue nuevamente al límite fijado.

Artículo $\mathbf{3 4}^{\circ}$. Utilidades.- Las utilidades se repartirán con base en los estados financieros de fin de ejercicio, previa determinación adoptada por la asamblea general de accionistas. Las utilidades se repartirán en proporción al número de acciones suscritas de que cada uno de los accionistas sea titular.

Artículo ${35^{\circ}}^{\circ}$.Resolución de conflictos.- Todos los conflictos que surjan entre los accionistas por razón del contrato social, salvo las excepciones legales, serán dirimidos por la Superintendencia de Sociedades, con excepción de las acciones de impugnación de decisiones de la asamblea general de accionistas, cuya resolución será sometida a arbitraje, en los términos previstos en la Cláusula 35 de estos estatutos.

Artículo 36 ${ }^{\circ}$. Cláusula Compromisoria.- La impugnación de las determinaciones adoptadas por la asamblea general de accionistas deberá adelantarse ante un Tribunal de Arbitramento conformado por un árbitro, el cual será designado por acuerdo de las partes, o en su defecto, por el Centro de Arbitraje y Conciliación Mercantil. El árbitro designado será abogado inscrito, fallará en derecho y se sujetará a las tarifas previstas por el Centro de Arbitraje y Conciliación Mercantil. El Tribunal de Arbitramento tendrá como sede el Centro de Arbitraje y Conciliación Mercantil. Se regirá por las leyes colombianas y de acuerdo con el reglamento del aludido Centro de Conciliación y Arbitraje.

Artículo $37^{\circ}$. Ley aplicable.- La interpretación y aplicación de estos estatutos está sujeta a las disposiciones contenidas en la Ley 1258 de 2008 y a las demás normas que resulten aplicables. 


\section{Capítulo IV}

\section{Disolución y Liquidación}

Artículo 38 . Disolución.- La sociedad se disolverá:

$1^{\circ}$ Por vencimiento del término previsto en los estatutos, si lo hubiere, a menos que fuere prorrogado mediante documento inscrito en el Registro mercantil antes de su expiración;

$2^{\circ}$ Por imposibilidad de desarrollar las actividades previstas en su objeto Social;

$3^{\text {o }}$ Por la iniciación del trámite de liquidación judicial;

$4^{\circ}$ Por voluntad de los accionistas adoptada en la asamblea o por decisión del accionista único;

$5^{\circ}$ Por orden de autoridad competente, y

$6^{\circ}$ Por pérdidas que reduzcan el patrimonio neto de la sociedad por debajo del cincuenta por ciento del capital suscrito.

Parágrafo primero.- En el caso previsto en el ordinal primero anterior, la disolución se producirá de pleno derecho a partir de la fecha de expiración del término de duración, sin necesidad de formalidades especiales. En los demás casos, la disolución ocurrirá a partir de la fecha de registro del documento privado concerniente o de la ejecutoria del acto que contenga la decisión de autoridad competente.

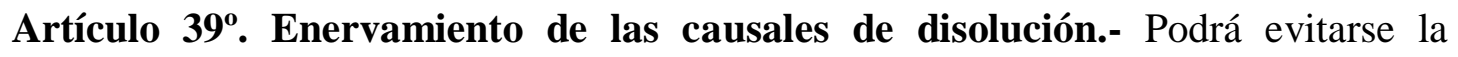
disolución de la sociedad mediante la adopción de las medidas a que hubiere lugar, según la causal ocurrida, siempre que el enervamiento de la causal ocurra durante los seis meses siguientes a la fecha en que la asamblea reconozca su acaecimiento. Sin embargo, este plazo será de dieciocho meses en el caso de la causal prevista en el ordinal $6^{\circ}$ del artículo 
anterior.

Artículo 40 . Liquidación.- La liquidación del patrimonio se realizará conforme al procedimiento señalado para la liquidación de las sociedades de responsabilidad limitada. Actuará como liquidador el representante legal o la persona que designe la asamblea de accionistas.

Durante el período de liquidación, los accionistas serán convocados a la asamblea general de accionistas en los términos y condiciones previstos en los estatutos y en la ley. Los accionistas tomarán todas las decisiones que le corresponden a la asamblea general de accionistas, en las condiciones de quórum y mayorías decisorias vigentes antes de producirse la disolución.

\section{Determinaciones relativas a la constitución de la sociedad}

1. Representación legal.- Los accionistas constituyentes de la sociedad han designado en este acto constitutivo, a Manuela Fernanda Forero Mejía, identificado con el documento de identidad No. 1049622952, como representante legal de CUBARA SAS, por el término de 1 año.

Manuela Fernanda Forero Mejía participa en el presente acto constitutivo a fin de dejar constancia acerca de su aceptación del cargo para el cual ha sido designado, así como para manifestar que no existen incompatibilidades ni restricciones que pudieran afectar su designación como representante legal de CUBARA SAS.

2. Actos realizados por cuenta de la sociedad en formación.- A partir de la inscripción del presente documento en el Registro Mercantil, CUBARA SAS,asume la totalidad de los derechos y obligaciones derivados de los siguientes actos y negocios jurídicos, realizados por cuenta de la sociedad durante su proceso de formación: 
3. Personificación jurídica de la sociedad.- Luego de la inscripción del presente documento en el Registro Mercantil, nombre de la empresa formará una persona jurídica distinta de sus accionistas, conforme se dispone en el artículo $2^{\circ}$ de la Ley 1258 de 2008.

Manuela Forero

Diana Archila

Presidente

Socio

CC 1049622952

CC 1049618722

\section{Requisitos y trámites de formalización de la empresa.}

\section{Pasos para Constituir y Registrar una Sociedad}

-Consulta del nombre en la Cámara de Comercio: Esta consulta se realiza personalmente o a través de la Web, con el fin de verificar que no exista registrado el nombre que se asignó a la empresa.

Elaborar el documento de constitución de la sociedad con el apoyo de los modelos y minutas, teniendo en cuenta:

- Por documento privado se pueden constituir por éste las empresas que al momento de constitución no tenga activos superiores a 500 SMMLV o una planta de trabajadores no superior a 10), salvo el caso de las S.A.S. o Empresas Unipersonales.

- Por escritura pública (obligatorio siempre que se aporte un inmueble), el cual podrá realizar dependiendo del tipo societario:

-Solicitar PRE-RUT ante las oficinas de la DIAN o a través de su página web www.dian.gov.co 
-Con el documento de constitución de la sociedad elaborado diríjase a las Oficinas del Banco Agrario de Colombia, para realizar el pago de impuesto de registro de conformidad con la Ley 223 de 1995, el cual debe ser liquidado como un acto con cuantía y sobre el $0.7 \%$ del capital social.

-Diligenciar el FORMULARIO DE REGISTRO ÚNICO EMPRESARIAL, el cual puede adquirir en cualquiera de nuestras oficinas.

-Anexar fotocopia del recibo de servicio público (agua, luz, gas,), cuya dirección de domicilio corresponda a la indicada en el PRE-RUT.

-Con los documentos antes mencionados diríjase a cualquiera de las Oficinas de nuestra Entidad para radicarlos (En caja en Cámara de Comercio los constituyentes deben hacer presentación personal, si los mismos no lo hicieron ante Notario). En caja el funcionario la nuestra Entidad liquidará los derechos de inscripción a cancelar, de acuerdo a los activos(Camara de Comercio de Tunja, 2012)

\section{Trámites y permisos de funcionamiento: patentes, licencias y otros.}

Haciendo las respectivas investigaciones, se concluyó que para el funcionamiento del Centro de acoplamiento Cultural, no se requiere permisos en lo que concierne a patentes y licencias, vale aclarar, que respecto a los derechos de autor, en el caso que las canciones interpretadas no sean compuestas por el artista, estos costos los asume el mismo, o bien puede incluirse en el costo de prestación del servicio.

\section{Estudio Financiero}

\section{Marco teórico y conceptual del estudio financiero}

La sistematización consiste en identificar y ordenar todos los ítems de inversiones, costos e ingresos que puedan deducirse del estudio previo. Este estudio tiene como objeto 
determinar cuál es el monto de los recursos económicos para la ejecución del proyecto y los costos totales de operación del proceso productivo y el monto de los ingresos que se aspira recibir en cada uno de los periodos. Los datos que son registrados en el estudio financiero so el resultado de los estudios previos de mercado, técnico y organizacional, los cueles van a ser utilizados para determinar la viabilidad económica del proyecto.

\section{Metodología del estudio financiero}

Ordenar y sistematizar la información de carácter monetario que proporcionaron las etapas anteriores, elaborar los cuadros analíticos y datos adicionales para la evaluación del proyecto y evaluar los antecedentes para determinar su rentabilidad.

Presupuesto de inversiones: inversiones fijas, capital de trabajo, fuentes de financiamiento

Tabla 17.

Inversiones Fijas.

\begin{tabular}{lll}
\hline \multicolumn{3}{c}{ Inversiones Fijas } \\
\\
\hline Maquinaria y equipo & 3347857 & 334786 \\
\hline Muebles y enceres & 2177254 & 217725 \\
\hline Total & 5525111 & 552511 \\
\hline
\end{tabular}

Fuente. Autoras

Las inversiones fijas necesarias para la puesta en marcha de proyecto son $\mathbf{\$ 5 . 5 2 5 , 1 1 1}$ correspondiente de maquinaria y equipo, muebles y enceres necesarios para cumplir con la producción. 
Tabla 18.

Gastos anuales de administración.

\begin{tabular}{|c|c|c|c|c|}
\hline \multicolumn{5}{|c|}{ Gastos Anuales Administración } \\
\hline Actividad & & Mensual & Cantidad & Anual \\
\hline Servicios Públicos & $\$$ & $300,000.00$ & 12.00 & 720,000 \\
\hline Arriendos & $\$$ & $600,000.00$ & 12.00 & $1,440,000$ \\
\hline Gastos Varios & $\$$ & $50,000.00$ & 12.00 & 600,000 \\
\hline Nomina Administración & $\$$ & $890,800.00$ & 12.00 & $10,689,600$ \\
\hline Contratación Prestación servicios & $\$$ & $407,490.37$ & 12.00 & $4,889,884$ \\
\hline Total & $\$$ & $2,248,290.37$ & & $18,339,484$ \\
\hline
\end{tabular}

Fuente. Autoras.

Tabla 19.

Capital de trabajo.

Diana Archila

\section{Capital de trabajo}

Manuela Forero

1200000

1200000

Fuente. Autoras.

Se presupuesta una capital de trabajo de $\mathbf{2 3 , 8 6 4 , 5 9 5 . 4 8}$ sumando de capital para la puesta en marcha, y las inversiones fijas en maquinaria y equipo más muebles y enceres, lo cual se financiaría por medio de los aportes de los dueños del centro de acoplamiento cultural, acordados en $\$ 12.000,000$ por cada una

Costos de producción: costos de fabricación, gastos administrativos, otros gastos indirectos.

Tabla 20.

Costos anuales de fabricación.

\begin{tabular}{lr}
\hline & Costos Anual fabricación \\
\hline costos insumos & 15724.34 \\
\hline Precio de Venta Estimado & 48500 \\
\hline Ventas Proyectadas & 48600 \\
\hline Ingreso Operacionales & 130934545 \\
\hline Costos Totales & 42455718 \\
\hline Ingresos Netos & 88478827 \\
\hline
\end{tabular}

Fuente. Autoras. 
Tabla 21.

Gastos Anuales de administración.

\begin{tabular}{|lrrrrr}
\hline \multicolumn{7}{c}{ Gastos Anuales Administración } \\
\hline \multicolumn{1}{|c}{ Actividad } & & Mensual & Cantidad & \multicolumn{1}{c}{ Anual } \\
\hline Servicios Públicos & $\$$ & $300,000.00$ & & 12.00 & 720,000 \\
\hline Arriendos & $\$$ & $600,000.00$ & 12.00 & $1,440,000$ \\
\hline Gastos Varios & $\$$ & $50,000.00$ & 12.00 & & 600,000 \\
\hline Nomina Administración & $\$$ & $890,800.00$ & 12.00 & $10,689,600$ \\
\hline Contratación Prestación servicios & $\$$ & $407,490.37$ & 12.00 & $4,889,884$ \\
\hline TOTAL & $\$$ & $2,248,290.37$ & & $18,339,484$ \\
\hline
\end{tabular}

Fuente. Autoras.

Tabla 22.

Otros Gastos Indirectos.

\begin{tabular}{lccc}
\hline \multicolumn{4}{c}{ Otros Gastos Indirectos } \\
\hline Tramite & & Valor & Entidad \\
\hline Registro Cámara de Comercio & $\$$ & $250,000.00$ & Cámara Comercio \\
\hline Adecuación & $\$$ & $2,000,000.00$ & \\
\hline Papelería & $\$$ & $500,000.00$ & \\
\hline \multicolumn{1}{l}{ Total } & & & \\
\hline
\end{tabular}

Fuente. Autoras

Ingresos y flujo de producción.

Tabla 23.

Ingresos y flujo de producción.

\begin{tabular}{|lrrrrrr}
\hline \multicolumn{7}{c}{ Ingresos y Flujo de Producción } \\
\hline Ventas & & 20000 & 30000 & $42,175.62$ & $\$ 54,828.31$ & $\$ 92,659.84$ \\
\hline $\begin{array}{l}\text { Ingresos } \\
\text { Operacionales }\end{array}$ & $\$ 53,888,888.89$ & $\$ 80,833,333.33$ & $\$ 113,639,872.13$ & $\$ 147,731,833.7$ & $\$ 249,666,799.0$ \\
\hline Costo Variable & $\$$ & $17,471,488.79$ & $\$ 26,207,233.19$ & $\$ 36,843,545.92$ & $\$ 47,896,609.70$ & $\$ 80,945,270.39$ \\
\hline Costo Fijo & $\$$ & $76,796,326.21$ & $\$ 76,796,326.21$ & $\$ 76,796,326.21$ & $\$ 76,796,326.21$ & $\$ 76,796,326.21$ \\
\hline Costo Total & $\$ 94,267,815.00$ & $\$ 103,003,559.40$ & $\$ 113,639,872.13$ & $\$ 124,692,935.9$ & $\$ 157,741,596.6$ \\
\hline Utilidad & $\$(40,378,926.11)$ & $\$(22,170,226.07)$ & $\$-$ & $\$ 23,038,897.86$ & $\$ 91,925,202.47$ \\
\hline
\end{tabular}

Fuente. Autoras. 


\section{Balance de inicio del proyecto.}

\section{Tabla 24.}

Balance de Inicio.

\begin{tabular}{|c|c|c|c|c|c|c|}
\hline & Año 0 & Año 1 & Año 2 & Año 3 & Año 4 & Año 5 \\
\hline \multicolumn{7}{|l|}{ BALANCE GENERAL } \\
\hline \multicolumn{7}{|l|}{ Activo } \\
\hline Efectivo & 0 & 11.427 .740 & 56.415 .994 & 147.473 .645 & 308.977 .177 & 576.792 .133 \\
\hline Cuentas X Cobrar & 0 & 0 & 0 & 0 & 0 & 0 \\
\hline Provisión Cuentas por Cobrar & & 0 & 0 & 0 & 0 & 0 \\
\hline Inventarios Materias Primas e Insumos & 0 & 0 & 0 & 0 & 0 & 0 \\
\hline Inventarios de Producto en Proceso & 0 & 0 & 0 & 0 & 0 & 0 \\
\hline Inventarios Producto Terminado & 0 & 0 & 0 & 0 & 0 & 0 \\
\hline Anticipos y Otras Cuentas por Cobrar & 0 & 0 & 0 & 0 & 0 & 0 \\
\hline Gastos Anticipados & 0 & 0 & 0 & 0 & 0 & 0 \\
\hline Total Activo Corriente: & 0 & 11.427 .740 & 56.415 .994 & 147.473 .645 & 308.977 .177 & 576.792 .133 \\
\hline Terrenos & 0 & 0 & 0 & 0 & 0 & 0 \\
\hline Construcciones y Edificios & 0 & 0 & 0 & 0 & 0 & 0 \\
\hline Maquinaria y Equipo de Operación & 5.525 .111 & 4.972 .600 & 4.420 .089 & 3.867 .578 & 3.315 .067 & 2.762 .556 \\
\hline Muebles y Enseres & 0 & 0 & 0 & 0 & 0 & 0 \\
\hline Equipo de Transporte & 0 & 0 & 0 & 0 & 0 & 0 \\
\hline Equipo de Oficina & 0 & 0 & 0 & 0 & 0 & 0 \\
\hline Semovientes pie de cria & 0 & 0 & 0 & 0 & 0 & 0 \\
\hline Cultivos Permanentes & 0 & 0 & 0 & 0 & 0 & 0 \\
\hline Total Activos Fijos: & 5.525 .111 & 4.972 .600 & 4.420 .089 & 3.867 .578 & 3.315 .067 & 2.762 .556 \\
\hline Total Otros Activos Fijos & 0 & 0 & 0 & 0 & 0 & 0 \\
\hline ACTIVO & 5.525 .111 & 16.400 .340 & 60.836 .083 & 151.341 .223 & 312.292 .244 & 579.554 .688 \\
\hline \multicolumn{7}{|l|}{ Pasivo } \\
\hline Cuentas X Pagar Proveedores & 0 & 0 & 0 & 0 & 0 & 0 \\
\hline Impuestos X Pagar & 0 & 3.588 .826 & 15.848 .108 & 35.096 .572 & 64.695 .706 & 109.546 .189 \\
\hline Acreedores Varios & & 0 & 0 & 0 & 0 & 0 \\
\hline Obligaciones Financieras & 0 & 0 & 0 & 0 & 0 & 0 \\
\hline Otros pasivos a LP & & 0 & 0 & 0 & 0 & 0 \\
\hline Obligacion Fondo Emprender (Contingente) & -18.474 .889 & -18.474 .889 & -18.474 .889 & -18.474 .889 & -18.474 .889 & -18.474 .889 \\
\hline PASIVO & -18.474 .889 & -14.886 .063 & -2.626 .781 & 16.621 .683 & 46.220 .817 & 91.071 .300 \\
\hline \multicolumn{7}{|l|}{ Patrimonio } \\
\hline Capital Social & 24.000 .000 & 24.000 .000 & 24.000 .000 & 24.000 .000 & 24.000 .000 & 24.000 .000 \\
\hline Reserva Legal Acumulada & 0 & 0 & 728.640 & 3.946 .286 & 11.071 .954 & 12.000 .000 \\
\hline Utilidades Retenidas & 0 & 0 & 6.557 .763 & 35.516 .578 & 99.647 .586 & 230.071 .428 \\
\hline Utilidades del Ejercicio & 0 & 7.286 .403 & 32.176 .461 & 71.256 .676 & 131.351 .887 & 222.411 .960 \\
\hline Revalorizacion patrimonio & 0 & 0 & 0 & 0 & 0 & 0 \\
\hline PATRIMONIO & 24.000 .000 & 31.286 .403 & 63.462 .865 & 134.719 .540 & 266.071 .428 & 488.483 .388 \\
\hline PASIVO + PATRIMONIO & 5.525 .111 & 16.400 .340 & 60.836 .083 & 151.341 .223 & 312.292 .244 & 579.554 .688 \\
\hline
\end{tabular}

Fuente. Autoras.

Flujo de fondos del proyecto: flujo neto de caja, flujo de financiación, flujo con y sin

financiación, flujo incremental. 


\section{Tabla 25}

\section{Flujo de fondos del proyecto.}

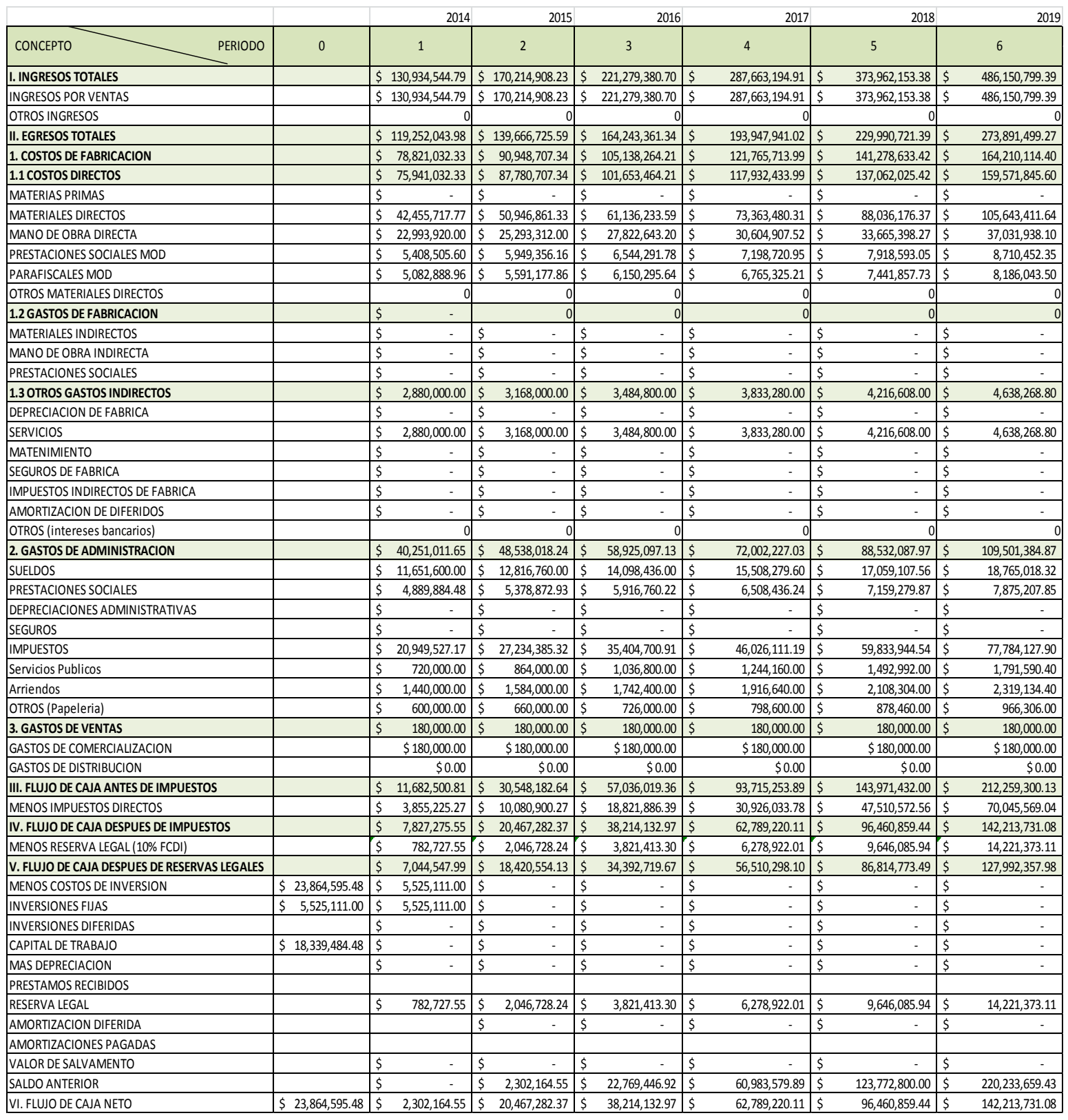

Fuente. Autoras. 


\section{Cálculo de indicadores para evaluación financiera del proyecto: TIO, VPN, TIR,RBC,}

PRI.

Tabla 26.

Cálculos de indicadores.

\begin{tabular}{|c|c|c|c|c|c|c|}
\hline & Año 0 & Año 1 & Año 2 & Año 3 & Año 4 & Año 5 \\
\hline \multicolumn{7}{|l|}{ Supuestos Macroeconómicos } \\
\hline Variación Anual IPC & & $4,00 \%$ & $3,25 \%$ & $3,01 \%$ & $3,02 \%$ & $3,02 \%$ \\
\hline Devaluación & & $8,00 \%$ & $2,28 \%$ & $4,55 \%$ & $-2,74 \%$ & $0,87 \%$ \\
\hline Variación PIB & & $5,00 \%$ & $5,00 \%$ & $5,00 \%$ & $5,00 \%$ & $5,00 \%$ \\
\hline DTF ATA & & $8,63 \%$ & $7,94 \%$ & $7,08 \%$ & $6,33 \%$ & $5,59 \%$ \\
\hline \multicolumn{7}{|l|}{ Supuestos Operativos } \\
\hline Variación precios & & N.A. & $20,0 \%$ & $20,0 \%$ & $20,0 \%$ & $20,0 \%$ \\
\hline Variación Cantidades vendidas & & N.A. & $20,0 \%$ & $20,0 \%$ & $20,0 \%$ & $20,0 \%$ \\
\hline Variación costos de producción & & N.A. & $15,6 \%$ & $15,8 \%$ & $16,0 \%$ & $16,2 \%$ \\
\hline Variación Gastos Administrativos & & N.A. & $20,6 \%$ & $21,4 \%$ & $22,2 \%$ & $23,0 \%$ \\
\hline Rotación Cartera (días) & & 0 & 0 & 0 & 0 & 0 \\
\hline Rotación Proveedores (días) & & 0 & 0 & 0 & 0 & 0 \\
\hline Rotación inventarios (días) & & 0 & 0 & 0 & 0 & 0 \\
\hline \multicolumn{7}{|l|}{ Indicadores Financieros Proyectados } \\
\hline Liquidez - Razón Corriente & & 9,74 & 4,16 & 4,28 & 4,73 & 5,19 \\
\hline Prueba Acida & & 10 & 4 & 4 & 5 & 5 \\
\hline Rotacion cartera (días), & & 0,00 & 0,00 & 0,00 & 0,00 & 0,00 \\
\hline Rotación Inventarios (días) & & 0,0 & 0,0 & 0,0 & 0,0 & 0,0 \\
\hline Rotacion Proveedores (días) & & 0,0 & 0,0 & 0,0 & 0,0 & 0,0 \\
\hline Nivel de Endeudamiento Total & & $79,2 \%$ & $43,4 \%$ & $28,8 \%$ & $22,5 \%$ & $19,3 \%$ \\
\hline Concentración Corto Plazo & & 0 & 1 & 1 & 1 & 1 \\
\hline Ebitda / Gastos Financieros & & $271,8 \%$ & $1507,0 \%$ & $4669,8 \%$ & $13543,8 \%$ & $48231,7 \%$ \\
\hline Ebitda / Servicio de Deuda & & $139,3 \%$ & $672,5 \%$ & $1699,8 \%$ & $3606,3 \%$ & $7090,7 \%$ \\
\hline Rentabilidad Operacional & & $8,7 \%$ & $25,8 \%$ & $39,4 \%$ & $50,3 \%$ & $59,1 \%$ \\
\hline Rentabilidad Neta & & $3,7 \%$ & $16,1 \%$ & $25,8 \%$ & $33,4 \%$ & $39,5 \%$ \\
\hline Rentabilidad Patrimonio & & $100,0 \%$ & $86,3 \%$ & $66,6 \%$ & $55,4 \%$ & $48,5 \%$ \\
\hline Rentabilidad del Activo & & $20,8 \%$ & $48,9 \%$ & $47,4 \%$ & $42,9 \%$ & $39,1 \%$ \\
\hline \multicolumn{7}{|l|}{ Flujo de Caja y Rentabilidad } \\
\hline Flujo de Operación & & 11.427 .740 & 46.193 .459 & 91.939 .081 & 162.076 .671 & 268.111 .649 \\
\hline Flujo de Inversión & -20.000 .000 & 0 & 0 & 0 & 0 & 0 \\
\hline Flujo de Financiación & 20.000 .000 & -8.204 .647 & -7.223 .512 & -6.289 .297 & -5.451 .582 & -4.689 .402 \\
\hline Flujo de caja para evaluación & -20.000 .000 & 11.427 .740 & 46.193.459 & 91.939 .081 & 162.076 .671 & 268.111.649 \\
\hline Flujo de caja descontado & -20.000 .000 & 9.684 .525 & 33.175 .423 & 55.956 .963 & 83.597 .344 & 117.194 .073 \\
\hline \multicolumn{7}{|l|}{ Criterios de Decisión } \\
\hline Tasa mínima de rendimiento a la que aspira el emprendedor & $18 \%$ & & & & & \\
\hline TIR (Tasa Interna de Retorno) & $170,82 \%$ & & & & & \\
\hline VAN (Valor actual neto) & 279.608 .329 & & & & & \\
\hline PRI (Periodo de recuperación de la inversión) & 0,17 & & & & & \\
\hline $\begin{array}{l}\text { Duración de la etapa improductiva del negocio ( fase de } \\
\text { implementación).en meses }\end{array}$ & 3 mes & & & & & \\
\hline $\begin{array}{l}\text { Nivel de endeudamiento inicial del negocio, teniendo en } \\
\text { cuenta los recursos del fondo emprender. ( AFE/AT) }\end{array}$ & $100,00 \%$ & & & & & \\
\hline $\begin{array}{l}\text { Periodo en el cual se plantea la primera expansión del } \\
\text { negocio (Indique el mes ) }\end{array}$ & 10 mes & & & & & \\
\hline $\begin{array}{l}\text { Periodo en el cual se plantea la segunda expansión del } \\
\text { negocio (Indique el mes) }\end{array}$ & 22 mes & & & & & \\
\hline
\end{tabular}

Fuente. Autoras.

Tasa mínima de rendimiento es la taza de $18 \%$ utilizada para todos los proyectos de rentabilidad. 
Tasa Interna de Retorno (TIR): quiere decir que el proyecto genera una rentabilidad a largo plazo del 171\%, lo que es bueno para tomar la decisión de reinvertir en el proyecto.

Valor presente neto: el VAN del proyecto fue igual a 279, 608,329 según esto el proyecto es aceptable ya que la inversión genera ganancias sobre la rentabilidad.

Periodo de recuperación de inversión: el PRI es de $0.17 \%$ es decir que el periodo de recuperación de inversión es de tres meses. 


\section{Conclusiones}

- En este proyecto se aborda la didáctica desde una dimensión socio gerencial, como un discurso propio de administración, en su entorno permitiéndole reflejar en la sociedad como funciona y se mueve el mercado dentro de la ciudad y cuán importante es el desarrollo de nuevos mercados para fortalecer la economía de la misma.

- Con la realización y análisis de mercado se determinó que es factible la puesta en marcha del Centro de acoplamiento cultural "CUBARA" en la ciudad de Tunja.

- De acuerdo a los resultados obtenidos del estudio de mercado se determinó que nuestra población objetivo será la población estudiantil de 18 a 35 años de la ciudad de Tunja que hayan utilizado y utilicen servicios de Café-bar con manifestaciones artísticas.

- La publicidad es importante para que los clientes potenciales conozcan el servicio ofrecido por esta razón se realizará utilizando: periódicos, folletos, internet y radio.

- Se ve como oportunidad de negocio la creación de un Centro de acoplamiento cultural, tomando como base la demanda insatisfecha encontrada.

- Dentro del análisis financiero se determinó que en una proyección de 5 años, la empresa deriva una TIR de 171\%, un VPN de \$279.608.329 una tasa mínima de rendimiento del 18\%; y un periodo de recuperación de $0.17 \%$ lo cual permite asegurar la viabilidad de la creación del Centro de acoplamiento cultural "Cubara” en la ciudad de Tunja.

\section{Recomendaciones}

- Promover en la ciudad de Tunja, la participación de manifestaciones artísticas por medio de gestión cultural, o como espectador de las mismas, trayendo nuevos enfoque empresariales en el campo artístico 
- La calidad del servicio depende en su mayoría del personal en servicio alcliente por esto se debe prestar atención en la capacitación y evaluación del personal.

- Es de gran valor crear alianzas con los artistas y fundaciones culturales de la ciudad de Tunja, y municipios cercanos para garantizar, los eventos artísticos planeados para el café cultual. 


\section{Bibliografía}

Miranda Miranda, Juan José. (2005). Gestión de Proyectos. M\&M Editores. Quinta edición. Bogotá.

Sapagchain, Nassir. (2000). Preparación y Evaluación de Proyectos. McGraw-Hill Interamericana de Chile Ltda. Cuarta edición.

Ruiz Gutiérrez, Jaime Alberto (2009). Gestión y Cultural En Tres Actos. UniandesEditores. Primera edición. Bogotá..

Red Colombiana de Teatro en Comunidad. (2006). Red Colombiana de Teatro en Comunidad ediciones. Primera Edición. Medellín.

Dane. Disponible (en liana). URL: http://www.dane.gov.co/

Toma Café. Disponible (en línea). URL: http://tomacafe.org/. 


\section{Anexos}




\section{Anexo 1 Encuesta}

\section{Centro de Encuentro Cultural}

El objetivo de esta encuesta es determinar la factibilidad de un centro de encuentro, a través de un café cultural, por medio de los estudio de gustos, preferencias, productos y servicios que en el café desea encontrar.

Agradecemos que sus respuestas sean lo más sinceras para lograr veracidad en nuestra investigación.

Nombre___ Sexo F__ M_ Edad

1. ¿Le gustaría que en la ciudad de Tunja, existiera un espacio donde la cultura y el café se unieran?

Sí _ No

2. ¿Conoce usted la existencia de un café cultural en la ciudad de Tunja?

$\mathrm{Si}$ Cual? No

3. Participaría en las distintas actividades culturales que se desarrollen en un café cultural?

Sí _ No

Si la respuesta de la anterior pregunta fue afirmativa siga con la 4ta pregunta, si fue negativa continúe con la 5 ta.

4. ¿De qué manera participaría en las diferentes actividades culturales?

a) Como artista (música, teatro, Danza)

b) Como expositor

c) Como espectador

5. ¿Cuánto estaría dispuesto a pagar por el servicio dentro de un café-bar donde se realicen actividades culturales?

a) Menos de $\$ 5.000$

b) De $\$ 5.000$ a $\$ 10.000$

c) De $\$ 10.000$ a $\$ 20.000$

d) De $\$ 20.000$ a $\$ 40.000$

e) Más de $\$ 40.000$

6. Cuando usted sale a un café-bar que le es mas conveniente, clasifique el orden de importancia siendo uno (1) el mas relevante y cinco (5) el de menos.

La cercanía

La forma del lugar

La calidad del producto 
La gente que acude al lugar

Actividades que se realicen en el lugar

7. ¿Qué es lo más importante para usted dentro de un café-bar?
a) Precio
b) Música
c) Ambientación
d) Agilidad en el servicio
e) Otro, Cual?

8. ¿Qué le gustaría encontrar en un café cultural? Seleccione varias opciones
a) Variedad de cafés
b) Cocteles
c) Licores
d) Aromáticas

9. ¿Qué actividades le gustaría encontrar en el café cultural?
a) Grupos de teatro
b) Tertulias
c) Ciclos de cine
d) Exposiciones (fotografía, pintura, escultura)
e) Música en vivo
f) Otro, cual?

10. Clasifique en qué orden de importancia es para usted las actividades culturales, siendo 5 el más importante y 1 el menos importante?

Exposiciones

Teatro

Danzas

Cine

Literatura

11. ¿Con que frecuencia a la semana visita usted un café-bar?

a) Una a dos veces por semana

b) Tres a cinco veces por semana

c) Todos los días

d) Ninguna

12. ¿para usted en qué lugar le gustaría que este ubicado el café cultural?

a) Centro 
b) Santa Inés

c) Cerca de Unicentro

d) Muiscas

e) otro Cual? 


\section{Anexo 2. Encuesta por internet}

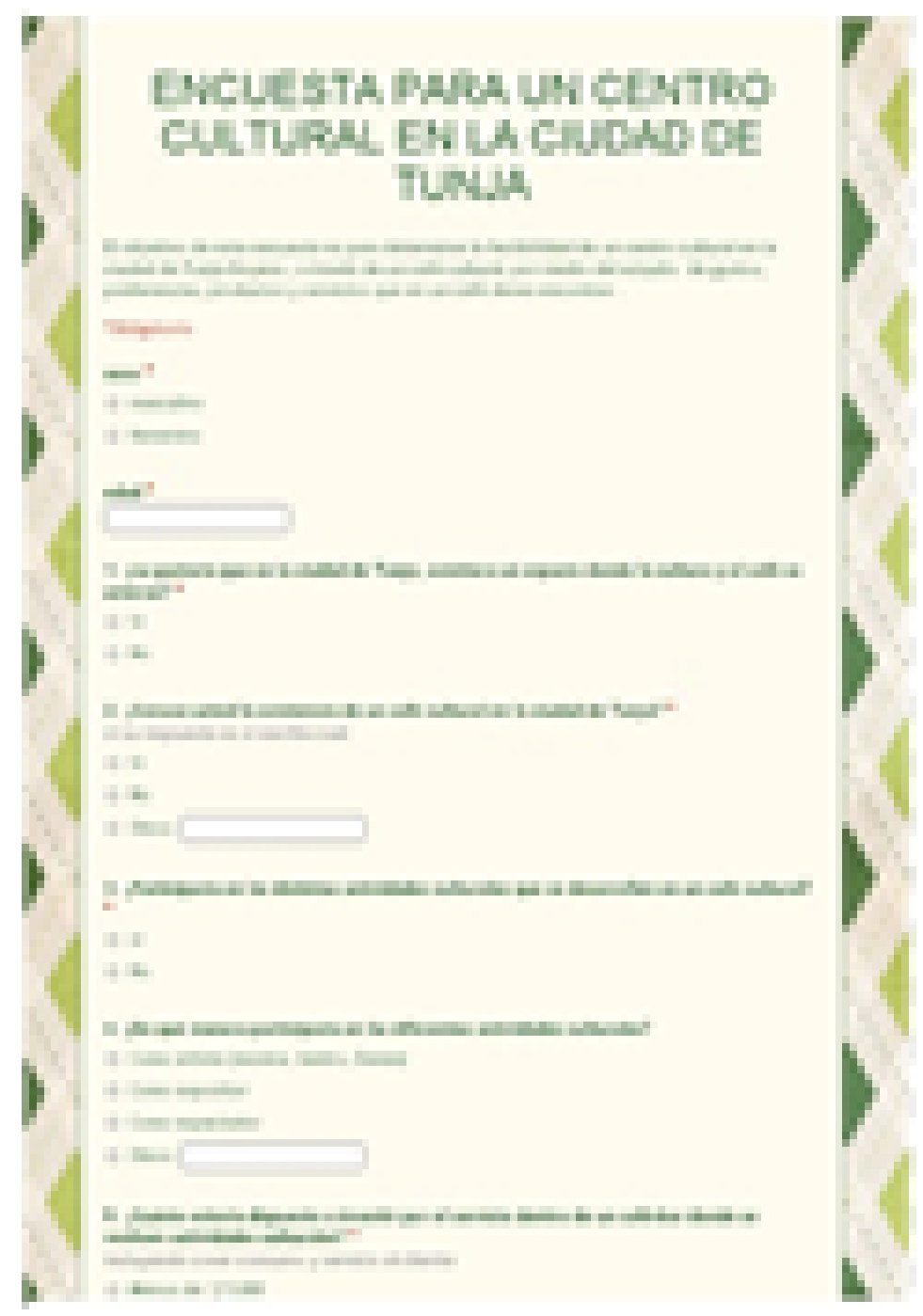




\section{Anexo 3. Registro único tributario}

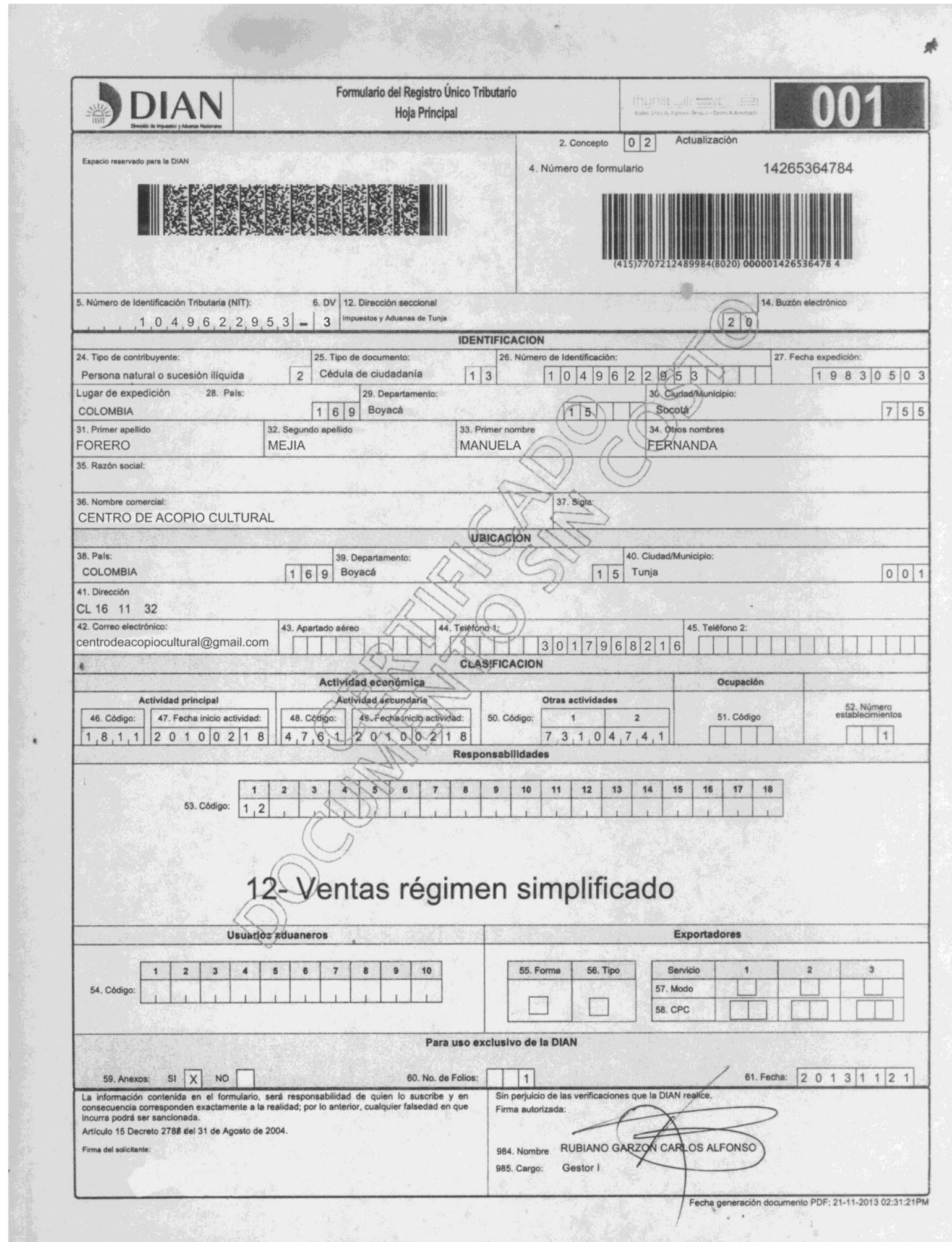




\section{Anexo 4. Cámara de comercio}

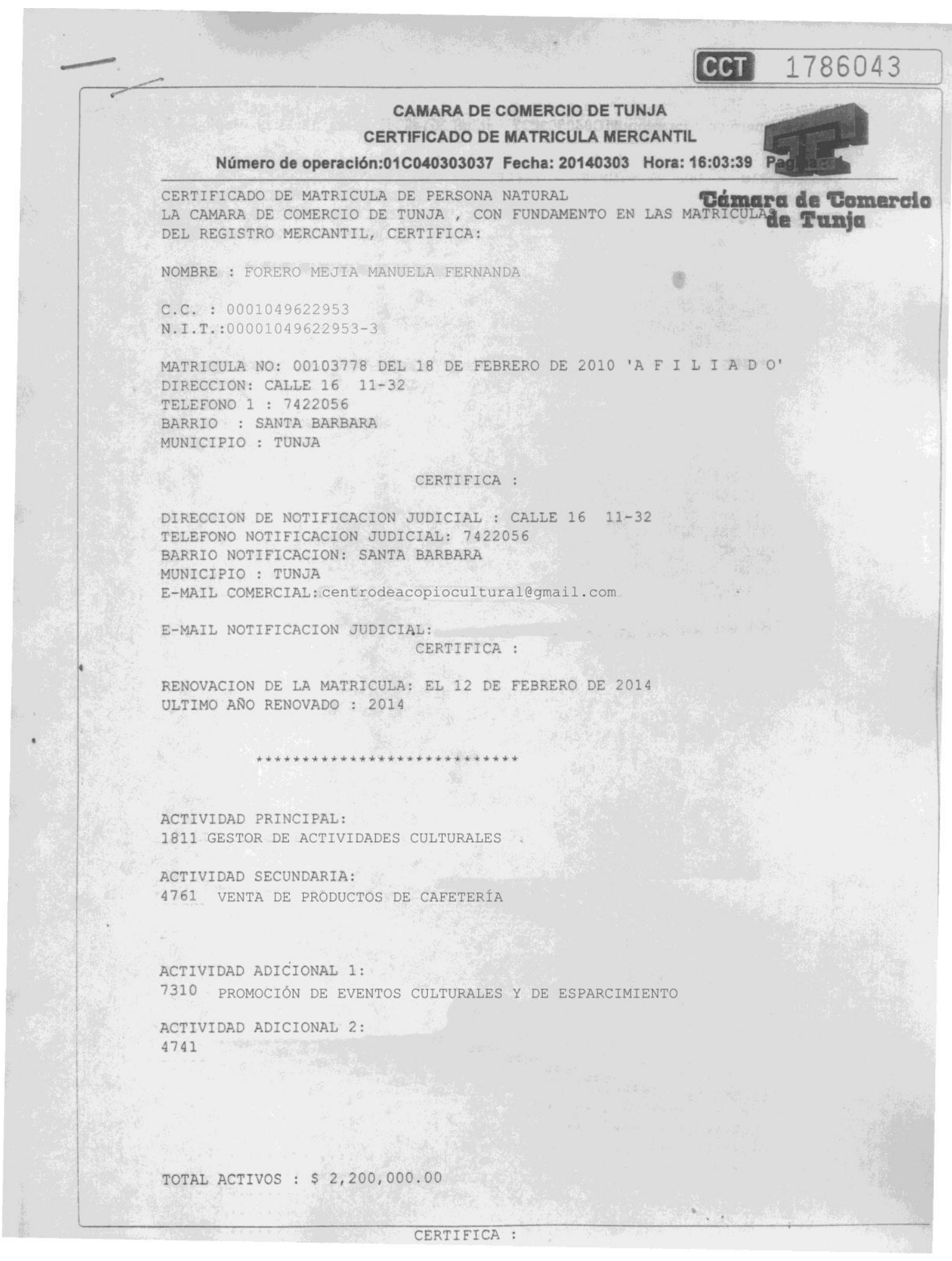




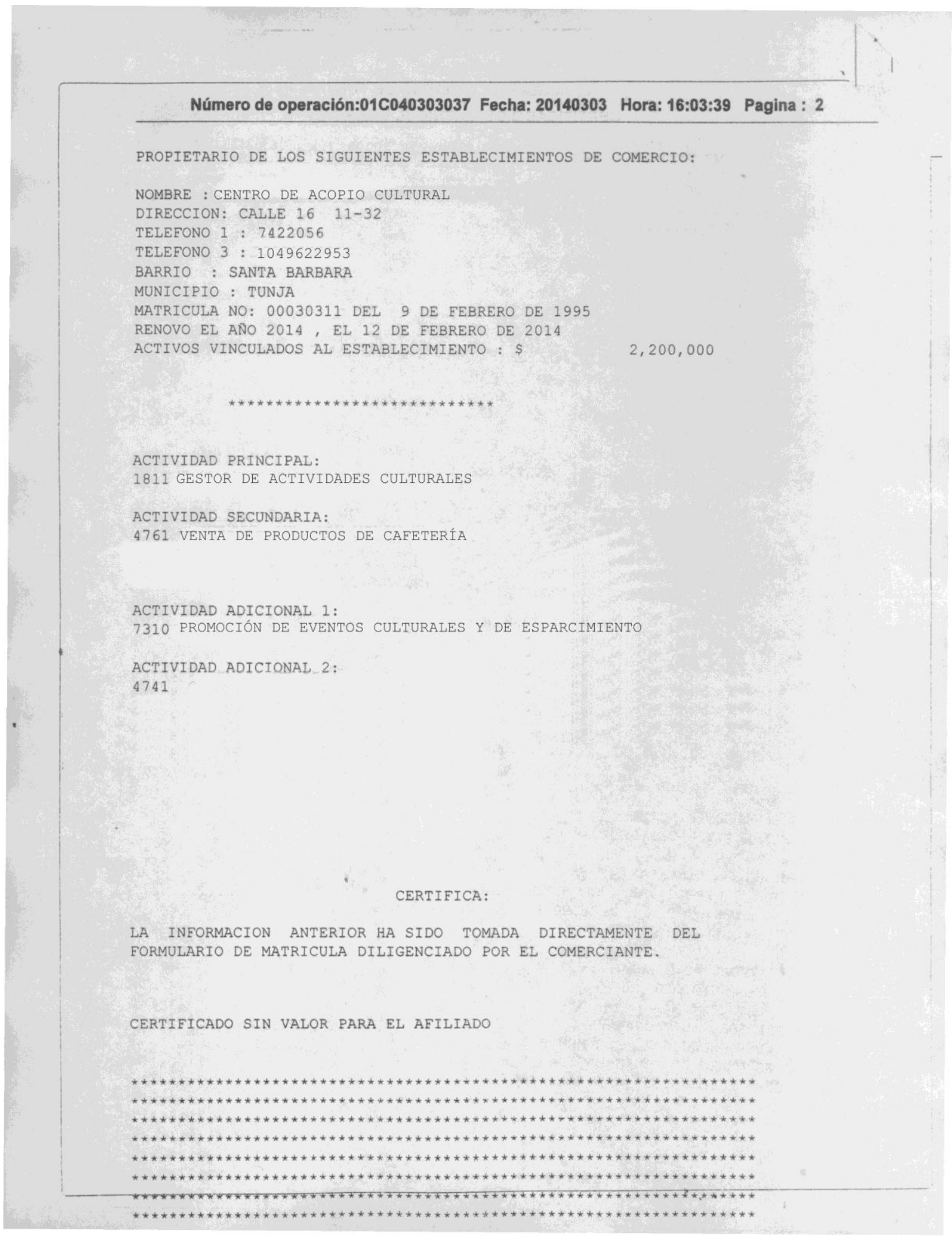


Anexo 5. Logo

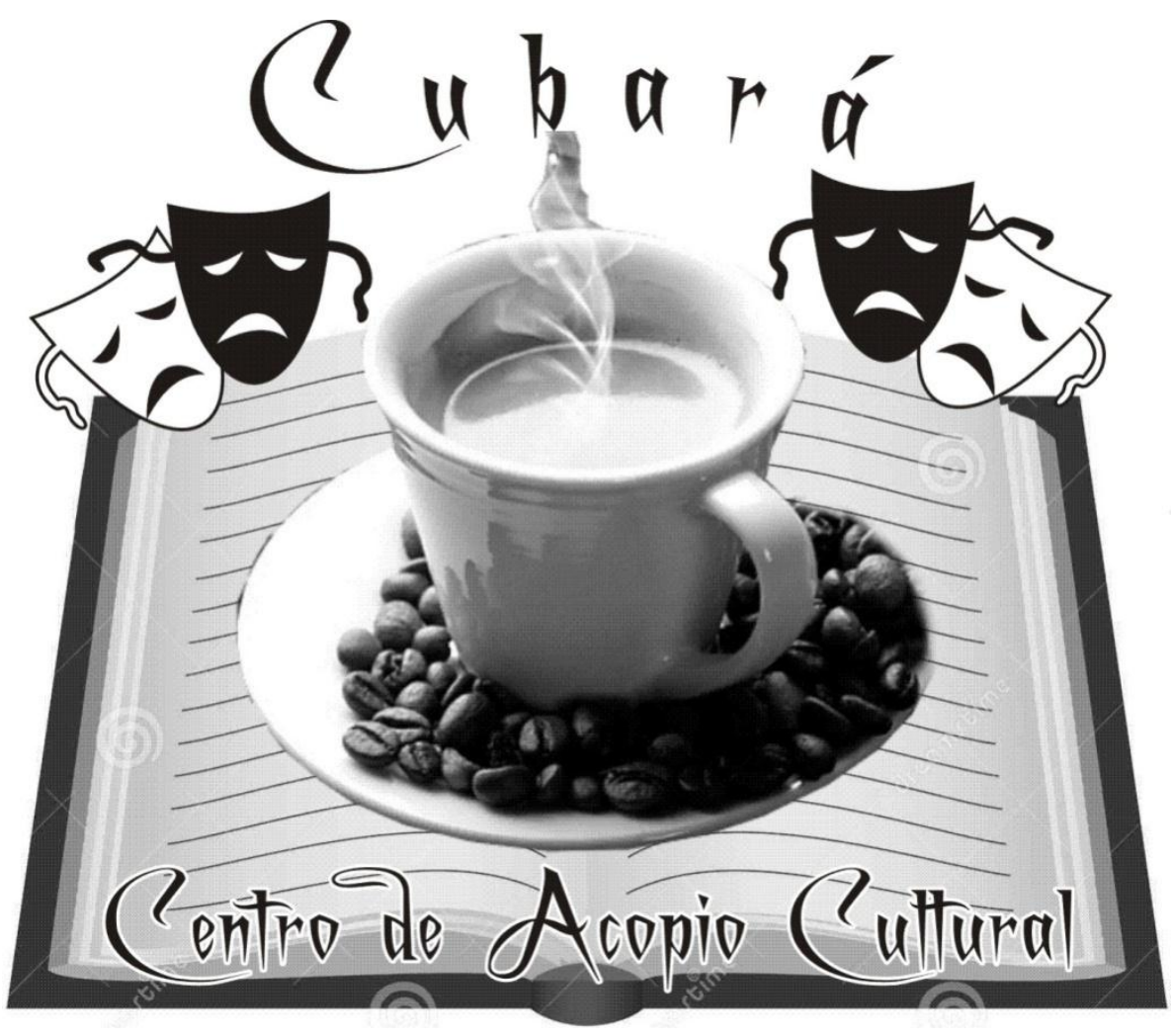

